\title{
Performance Testing of
} Radiobioassay Laboratories:

In Vitro Measurements (Urinalysis), Final Report

\author{
J. A. MacLellan \\ R. J. Traub \\ D. R. Fisher
}

March 1988

Prepared for the U.S. Department of Energy Assistant Secretary for

Environment, Safety, and Health

under Contract DE-AC06-76RLO 1830

Pacific Northwest Laboratory

Operated for the U.S. Department of Energy

by Battelle Memorial Institute 


\section{DISCLAIMER}

This report was prepared as an account of work sponsored by an agency of the United States Government. Neither the United States Governmentnor any agency thereof, nor Battelle Memorial Institute, nor any or their employees, makes any warranty, expressed or implied, or assumes any legal liability or responsibility for the accuracy, completeness, or usefulness of any information, apparatus, product, or process disclosed, or represents that its use would not infringe privately owned rights. Referenceherein to any specific commercial product, process, or service by trade name, trademark, manufacturer, or otherwise does not necessarily constitute or imply its endorsement, recommendation, or favoring by the United States Governmentor any agency thereof, or Battelle Memorial Institute. The views and opinions of authors expressed herein do not necessarily state or reflect thoseof the United States Governmentor any agency thereof, or Battelle Memorial Institute.

\section{PACIFIC NORTHWEST LABORATORY operated by \\ BATTELLE MEMORIAL INSTITUTE for the UNITED STATES DEPARTMENT OF ENERGY under Contract DE-AC06-76RLO 1830}

\begin{tabular}{|c|c|}
\hline \multirow{3}{*}{\multicolumn{2}{|c|}{$\begin{array}{l}\text { Printed in the United States of America } \\
\text { Available from } \\
\text { National Technical Information Service }\end{array}$}} \\
\hline & \\
\hline & \\
\hline \multicolumn{2}{|c|}{$\begin{array}{l}\text { United States Department of Commerc } \\
\text { 5285 Port Royal Road }\end{array}$} \\
\hline \multicolumn{2}{|c|}{ Springfield, Virginia 22161} \\
\hline \multirow{2}{*}{\multicolumn{2}{|c|}{$\begin{array}{l}\text { NTIS Price Codes } \\
\text { Microfiche A01 }\end{array}$}} \\
\hline & \\
\hline \multicolumn{2}{|c|}{ Printed Copy } \\
\hline & Price \\
\hline Pages & \\
\hline 001-025 & $\mathrm{A} 02$ \\
\hline $026-050$ & $\mathrm{~A} 03$ \\
\hline 051-075 & A04 \\
\hline 076-100 & A05 \\
\hline $101-125$ & A06 \\
\hline $126-150$ & $\mathrm{~A} 07$ \\
\hline $151-175$ & $\mathrm{~A} 08$ \\
\hline $176-200$ & A09 \\
\hline $201-225$ & A010 \\
\hline $226-250$ & A011 \\
\hline 251-275 & A012 \\
\hline $276-300$ & A013 \\
\hline
\end{tabular}


PERFORMANCE TESTING OF RADIOBIOASSAY LABORATORIES:

I N VITRO MEASUREMENTS

(URINALYSIS), FINAL REPORT
J. A. MacLellan
R. J. Traub
D. R. Fisher

March 1988

Prepared for

the U.S. Department of Energy

Assistant Secretary for

Environment, Safety, and Health

under Contract DE-AC06-76RLO 1830

Pacific Northwest Laboratory

Richland, Washington 99352 


\section{FORENORD}

In recent years, the U.S. Department of Energy (DOE), along with other federal agencies, has been assessing the feasibility of establishing a performance testing or accreditation program for occupational exposure measurements. Focus has been placed on personnel dosimetry, bioassay, and radiation protection instrumentation. The pathway for program development has been to encourage the development of performance standards by national consensus standards organizations, to evaluate the feasibil ity and technical appropriateness of the standards for application in DOE operations, and to develop and implement a routine performance testing program. These steps were completed for personnel dosimetry with the establishment of the Department of Energy Laboratory Accreditation Program (DOELAP). The DOE is now focusing on programs for radiation protection instrumentation and bioassay.

This report is one of a series of studies related to the performance of radiobioassay laboratories. It summarizes the results of a two-round nationwide in vitro bioassay intercomparison study based on draft ANSI Standard N13.30 "Performance Criteria for Radiobioassay. "

The Interagency Committee for Occupational Exposure Measurements, chaired by a representative of the National Bureau of Standards (NBS), has begun to evaluate the establishment of a bioassay accreditation program. The DOE plans to implement a performance testing program and will work closely with the Interagency Committee to establish a program that is consistent with the needs of the DOE and other federal agencies.

To ensure consistency in our programs, we are working very closely with the U.S. Nuclear Regulatory Commission (NRC) on feasibility studies of the standard. We gratefully acknowledge their technical contributions and joint sponsorship of earlier portions of the study. 
Accurate and consistent bioassay measurements are essential to the correct assessment of internal occupational exposure to radioactive materials. We strongly believe that continued efforts are needed to improve this component of internal exposure control.

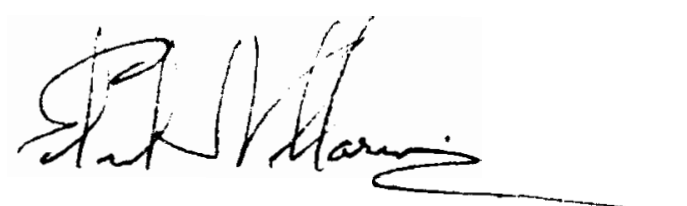

E. J. Vallario, Acting Director Radiological Controls Division Office of Nuclear Safety U.S. Department of Energy 


\section{EXECUTIVE SUMMARY}

Accurate bioassay measurements are essential to correctly assess internal exposure to radioactive materials. To address the necessity for accurate measurements, Health Physics Society (HPS) Working Group 2.5 prepared a draft American National Standards Institute (ANSI) standard of performance for radiobioassay laboratories. The draft standard provides values for an acceptable minimum detectable amount (AMDA), and limits for relative bias $\left(B_{r}\right)$ and relative precision $\left(S_{A}, S_{B}\right)$. The minimum detectable amount (MDA) is the smallest amount of radioactive material detectable using a specified bioassay procedure and instrumentation. The AVDA is the minimum MDA designated as acceptable by the draft standard; AMDAs are specific to a radionuclide and analysis type.

This report is part of a project to study the appropriateness of $\mathrm{draft}$ ANSI Standard N13.30, "Performance Criteria for Radiobioassay." The project involved:

- a nationwide, two-round intercomparison study to test the analytical performance of both in vitro and in vivo bioassay laboratories and to test their abilities to meet the minimum performance criteria specified in the draft ANSI standard

- tasks relatedt o establishing an accreditation laboratory, such as formulating test matrices, determining source distribution effects characteristic of in vivo phantoms, and preparing test manuals and procedures.

This report provides results of the two-round nationwide in vitro bioassay intercomparison study.

Conclusions were based on analyses by 35 bioassay laboratories of nearly 1400 artificial urine samples containing known quantities of radionuclides. The test radionuclides were ${ }^{3} \mathrm{H},{ }^{89} \mathrm{Sr},{ }^{90} \mathrm{Sr},{ }^{238} \mathrm{Pu},{ }^{241} \mathrm{Am},{ }^{137} \mathrm{Cs},{ }^{60} \mathrm{Co}$, and natural uranium. The data reported included background count rates, total sample counts, counting times, counting efficiencies, sample yields, and estimated errors of the determinations. The measurement data were evaluated 
according to statistical methods presented in the November 1985 version of the draft ANSI Standard N13.30. If a laboratory failed a performance test for any one of the three criteria', the laboratory was considered to have failed the test for that category.

The study results pointed out that many of the participating laboratories had difficulty meeting the performance criteria specified in the draft ANSI Standard N13.30. Failure to meet the criteria in alpha spectrometry occurred primarily because of calculated MDAs which were greater than the specified AMDAs. Uranium analysis failures occurred because of a combination of unacceptable MDAs and relative biases $\left(B_{r}\right)$. The causes of failure in the gamma spectrometry were equally distributed between the MDA and relative bias $\left(B_{r}\right)$ criteria. The liquid scintillation category had the fewest failures. The general beta-counting category had the most failures, possibly because of the extensive preparatory chemistry required during strontium analyses. Radionuclide categories which over $50 \%$ of the participants failed included ${ }^{89} \mathrm{Sr},{ }^{238} \mathrm{Pu}$, and ${ }^{241} \mathrm{Am}$ (83\%, $55 \%$, and $67 \%$, respectively).

Although testing of relative bias and relative precision error for a radionuclide is currently limited by the standard to levels greater than 10 times the AMDA, the differences between the high and low concentration testing levels in the percentage of laboratories failing the criteria are still of interest. As might be expected, testing at 2 to 5 times the AMDA resulted in higher failure percentages than when the testing concentrations were at 10 or more times the AMDA Although the difference was consistent at about $5 \%$ the confidence level for both rounds of testing, it was not statistically significant at the $90 \%$ confidence level. If the testing level were to be lowered from 10 to 3 times the ANDA at a future date, failures would not be expected to increase significantly.

Overall, one-third of the participating laboratories failed the MDA criterion, one-fourth failed the relative bias criterion, and one-tenth failed both the relative bias and MDA criteria. There were no discernible trends identified for measurement performance from the first to second round of testing. This finding contradicted the expectations of those who, before analyzing the data, believed that laboratories would improve their performance after the first round of participation. 
The primary objective of this project was to evaluate the appropriateness of test criteria in the draft ANSI Standard N13.30. Performance testing was therefore designed to determine whether the criteria are reasonably achievable by active radiobioassay laboratories, to provide relative precision and relative bias estimators for the participating laboratories, and to recommend improvements to the draft standard. Based on two rounds of in vitro testing, staff concluded that the performance criteria selected are appropriate and are achievable by most candidate laboratories. The following specific conclusions were drawn:

- The ANDA criteria are the most difficult for the laboratories to meet.

- The relative bias criterion is second in difficulty. Relative precision presented little problem for the laboratories.

- The performance criteria of the draft standard are attainable, but many laboratories will be required to make significant improvements in performance.

The draft standard identifies the laboratory performance levels necessary to meet radiation protection needs. The primary benefit of the draft standard will be to provide a single standard against which analytical performance may be measured. To derive the maximum benefit from the standard, performance testing should continue. Although relative precision and, thus, MDAs may be improved through internal quality control, relative bias improvement may-require a quality control program external to the facility to ensure that all facilities are calibrated to the same standard.

Recommendations for the revision of $\mathrm{draft}$ ANSI Standard N13.30 include:

- a revised formula for the relative precision calculation $\left(S_{A}\right)$, to allow summation over more than one activity level

- changes in the symbols used for relative precision, to decrease confusion with standard deviation estimators

- site visits by testing laboratory personnel, to audit the performance testing program. 



\section{ACKNOMEDGMENTS}

The authors would like to acknowledge Drs. J. M. R. (Robin) Hutchinson and K. G. W. (Ken) Inn of the National Bureau of Standards who kindly supplied the standard solutions of radionuclides for this study (under separate contract with NRC) and who, in addition,, provided many valuable suggestions and comments regarding technical aspects of sample preparation.

The intercomparison study is a Task under the Internal Dosimetry Evaluation and Upgrade Project at the Pacific Northwest Laboratory (PNL). The overall occupational radiation protection research program at PNL is managed by Jack M. Selby of PNL's Health Physics Department. Jack has provided overall management and research direction for this study since its inception in 1981.

We wish to thank the laboratories who willingly invested the time and money necessary to participate in this study. Because of their participation, we were able to provide the Health Physics Society Working Group 2.5 with invaluable information on performance capabilities of active service laboratories. This information provides the basis for a workable, practicable standard, from which the entire bioassay community will benefit.

We also wish to extend appreciation to our technical editors Cornelia Brim and Peggy Upton and to our typists Marianna Cross, Lyn Myers, and Claudia Burk. 



\section{GLOSSARY $^{(a)}$}

acceptable minimum detectable amount (AMDA) - The amount of radioactive material that technicians should be able to measure, assuming that the samples are free of interference from other radionuclides (unless specifically addressed). The values listed should not be construed as the absolute minimum detectable amount, but rather as an acceptable minimum detectable amount based on good practice and need.

activity - Disintegration rate of a specified quantity of radioactive materia stated in nuclear transformation rate, becquerels, curies, or other acceptable units.

appropriate blank - A sample, person, or phantom that is, ideally, identical in physiochemically- and radiologically-significant ways with the sample, person, or phantom to be analyzed. The appropriate blank may contain ambient quantities of the analytes. For direct bioassay, the appropriate blank may also be the subject of analysis, if one analyzes a portion of the count versus energy spectrum that is unaffected by the radionuclide of interest and if one applies a correction factor appropriate for obtaining a blank count for the spectral region(s) of interest. An appropriate blank provides the necessary signal response in the final measurement process so that signals resulting from ambient amounts of the analyte, interfering nuclides, and extraneous background radiation may be subtracted from signals from routine samples to permit detection and measurement of an additional amount of analyte above the ambient amount of the analyte normally contained in the medium of interest.

background - Ambient signal response recorded by measurement instruments that is independent of radioactivity contributed by the radionuclides being measured in the person or sample.

bias - (a) The deviation of the expected value of a random variable from a corresponding correct value. (b) A fixed deviation from the true value that remains constant over replicated measurements within the statistical precision of the measurement. (Synonyms: deterministic error, fixed error, systematic error.)

bioassay - Another term for radiobioassay.

coefficient of variation $\left({ }_{A}\right)$ - The quotient of the estimated standard deviation of a series ot determinations, $x_{1}, x_{2}, \ldots x_{i}, \ldots x_{N}$, of a quantity divided by the mean value of $x_{i}$; i.e.,

(a) Definitions are taken from draft ANSI Standard N13.30, except for "t-statistic" and "t-test", which were defined specifically for this report. 


$$
\begin{aligned}
& S_{A}=\left[\sum_{i=1}^{N}\left(x_{i}-\bar{x}\right)^{2} /(N-1)\right]^{\frac{1}{2}} / \bar{x}=\left[\sum_{i=1}^{N}\left(x_{i} / \bar{x}-1\right)^{2} /(N-1)\right]^{\frac{1}{2}} \\
& \text { where } \bar{x}=\sum_{i=1}^{N} x_{i} / N
\end{aligned}
$$

or for a single measurement the quotient of the estimate of the standard deviation (i.e., Poisson) divided by the value of the single measurement. (synonymous with the standard deviation, multiplied by 100 when expressed as percent).

concentration - The quantity of radioactive material in units of activity (or mass) per unit of volume or mass of a medium.

confidence interval - The interval delineating an estimate of a quantity within which the correct value of the quantity is expected to be (with a specified probability).

direct bioassay - Measurements of radioactive material in the human body using instrumentation that detects radiation emitted from the radioactive material inside the body. (Synonymous with in vivo measurement.)

indirect bioassay - Measurements to determine the presence of or to estimate - the amount of radioactive material in excreta, or other fluids, hair, breath, etc. removed from the body. (Synonymous with in vitro measurement. )

in vitro measurement - Synonymous with indirect bioassay.

in vivo measurement - Synonymous with direct bioassay.

minimum detectable amount (MDA) - The smallest amount of a radionuclide in a sample that will be detected with a $\beta$-probability of non-detection (Type II error) with an a-probability of erroneously detecting that radionuclide in an appropriate blank sample (Type I error). For this standard, the a and $\beta$ probabilities are both set at 0.05. (See definition for acceptable minimum detectable amount.)

phantom - A simulated person or part of a person used for calibration of in vivo measurement systems. A phantom is sometimes constructed to allow placement of radionuclides in a geometry representing internal depositions.

precision - Dispersion of measurements with respect to a measure of location or central tendency. 
precision statistic - An estimator of precision calculated from a finite sample using a specified formula.

quality assurance (QA) - Planned and systematic actions necessary to provide adequate confidence that analyses, measurements, or surveillance programs are satisfactory.

quality control (QC) - Actions that control the attributes of the analytical process, standards, reagents, measurement equipment, components, system, or facility according to predetermined quality requirements.

radiobioassay - Measurement of radioactive material in the body or in sample excreted or removed from the body.

relative bias - The quotient of the bias and the "true" value.

relative standard deviation - Synonymous with coefficient of variation.

relative precision - The quotient of the dispersion of the measurement and either the true. value or the mean of the measurement.

service laboratory - Laboratory performing direct and/or indirect radiobioassay measurements for and in behalf of a user of radioactive material.

standard deviation - The estimated dispersion of a set of measurements as given in the equation for coefficient of variation.

t-statistic - A statistical distribution in which the deviation of the measured mean from the assumed mean is divided by the standard deviation of the measured mean $[t=(x-\mu) /(s / n)]$. As the number of samples in a population increases, $t$ approximates the standard normal distribution.

t-test - A statistical test used to estimate the deviation of a measured value from an assumed mean.

unbiased - Measurement of a random variable is unbiased if it has zero bias, i.e., if the expected value of the measurement is equal to the correct value of the measured quantity. 



\section{CONTENTS}

FOREWORD

EXECUTIVE SUMMARY

ACKNOWLEDGMENTS

$\mathrm{ix}$

GLOSSARY

INTRODUCTION

QUALITY OF RADIOBIOASSAY MEASUREMENTS $\ldots \ldots \ldots \ldots \ldots \ldots \ldots \ldots \ldots . . \ldots 1$

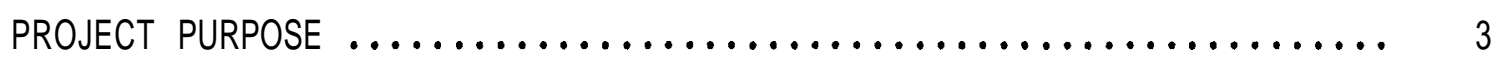

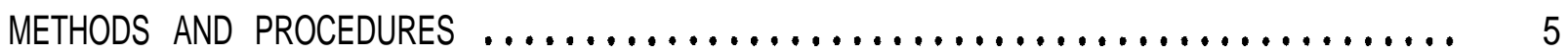

LABORATORY PARTICIPATION ............................... 5

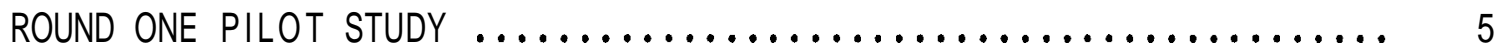

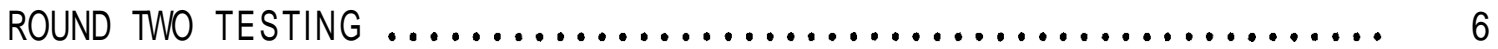

SURVEY OF MINIMUM DETECTABLE AMOUNT AND $\ldots \ldots \ldots \ldots \ldots \ldots \ldots \ldots . . \ldots 7$

ESTIMATED ANALYTICAL ERROR

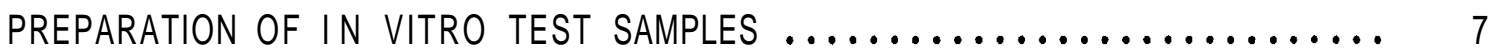

ARTIFICIAL URINE SAMPLE IDENTIFICATION AND SHIPMENT TO $\ldots \ldots \ldots \ldots .10$ PARTICIPATING LABORATORIES

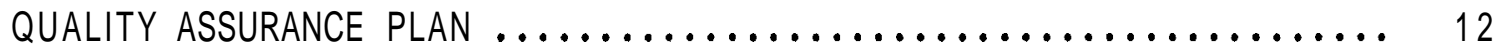

Quality Assurance for Participating Laboratories ............ 12

Third-Party Crosscheck of Samples .................... 12

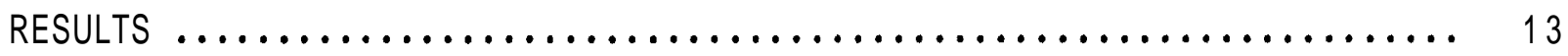

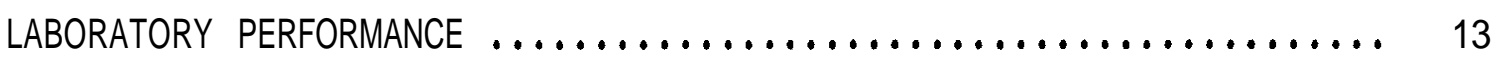

NATURAL VERSUS ARTIFICIAL URINE COMPARISON $\ldots \ldots \ldots \ldots \ldots \ldots \ldots . . \ldots, 32$

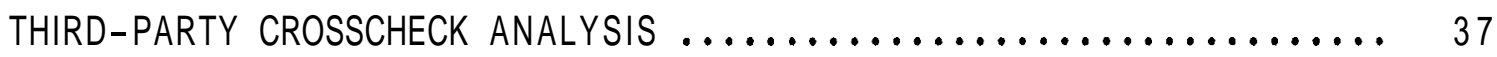


APPROPRIATENESS OF PERFORMANCE CRITERIA $\ldots \ldots \ldots \ldots \ldots \ldots \ldots \ldots \ldots . \ldots . \ldots . \ldots . \ldots$

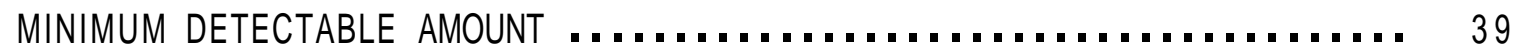

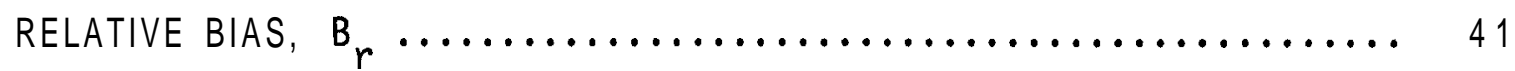

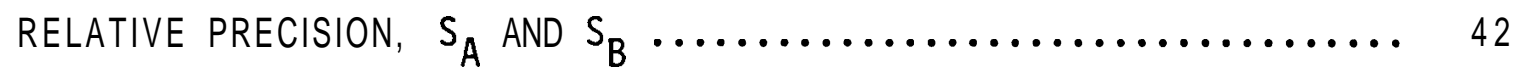

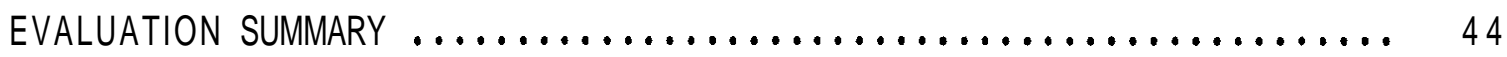

RECOMMENDED REVISIONS TO THE DRAFT ANSI STANDARD N13.30 $\ldots . . . \ldots \ldots . . .47$

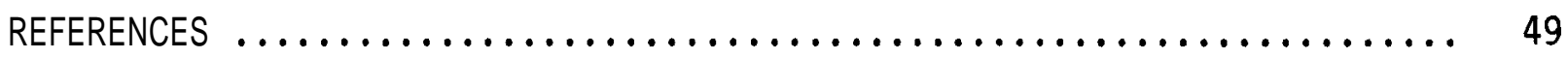

APPENDIX A - SAMPLE LETTER, TEST CATEGORIES, AND MDA .............. A.I

APPENDIX B - SAMPLE PREPARATION PROCEDURE ....................... B.I

APPENDIX C - INSTRUCTIONS TO PARTICIPATING IN VITRO LABORATORIES ...... C.I

APPENDIX D - IN VITRO MEASUREMENTS REPORT FORM ................... D.I

APPENDIX E - DETERMINATION OF MINIMUM DETECTABLE AMOUNTS $\ldots . . \ldots \ldots \ldots$..... E.

APPENDIX F - IN VITRO BIOASSAY RESULTS ....................... F.I

.APPENDIX G - PROPAGATION OF ERROR IN SPIKED ARTIFICIAL ............. G.I URINE SAMPLES 


\section{FIGURES}

1 Sample Label for Artificial Urine Sample Bottles ............. 11

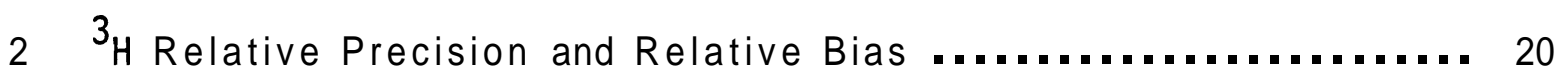

$3{ }^{89} \mathrm{Sr}$ Relative Precision and Relative Bias .................. 20

$4{ }^{90}$ Sr Relative Precision and Relative Bias .................. 21

$5 \quad 238$ Pu Relative Precision and Relative Bias ................. 21

$6 \quad{ }^{241}$ Am Relative Precision and Relative Bias ................ 22

7 Natural Uranium Relative Precision and Relative Bias .......... 22

$8{ }^{60}$ Co Relative Precision and Relative Bias .................. 23

$9 \quad{ }^{137}$ Cs Relative Precision and Relative Bias ............... 23

10 Normalized MDA Results $\ldots \ldots \ldots \ldots \ldots \ldots \ldots \ldots \ldots \ldots \ldots \ldots \ldots \ldots \ldots \ldots \ldots$

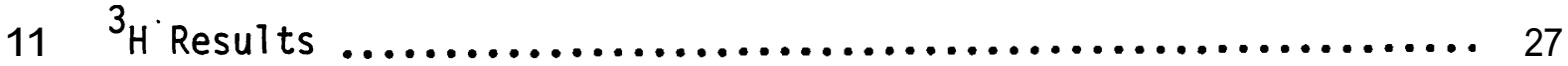

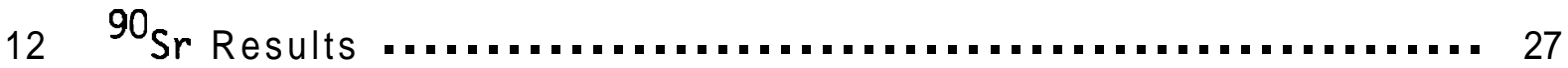

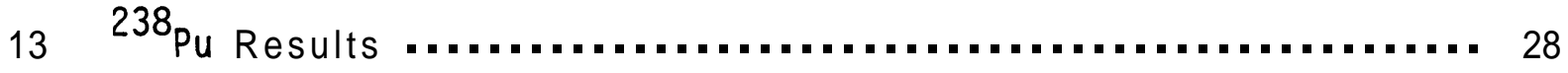

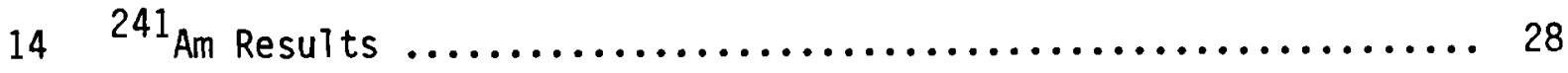

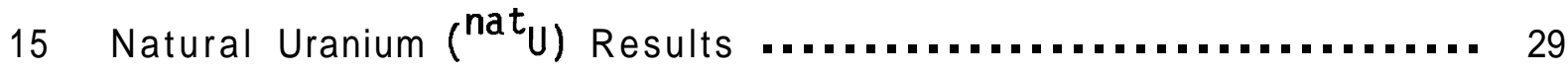

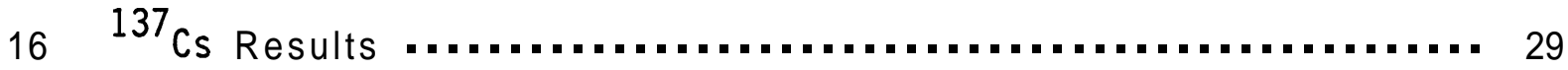

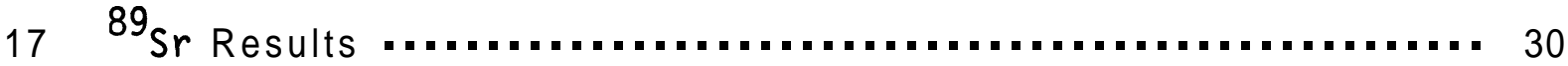

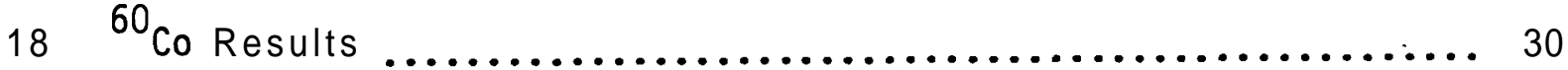




\section{TABLES}

1 Chemical Form of Radionuclides Supplied by NBS ............. 7

2 In Vitro Testing Categories. Radionuclides. and .............. 8 Testing Levels

3 Artificial Urine Recipe $\ldots \ldots \ldots \ldots \ldots \ldots \ldots \ldots \ldots \ldots \ldots \ldots \ldots \ldots$

4 Percentage of Participating Laboratories That .............. 13 Reported Test Results

5 Summary of In Vitro Testing Results .................... 15

6 In Vitro Testing Results by Nuclide Category ............... 17

7 MDAs for Laboratories Participating in Both Rounds ............ 26

8 Changes in Results for Laboratory Participation in ............ 26 Both Rounds

9 Artificial versus Natural Urine Comparison with ${ }^{238} \mathrm{Pu} . . . . . . . . .33$

10 Artificial versus Natural Urine Comparison with ${ }^{90}$ Sr .......... 34

11 Artificial versus Natural Urine Comparison with ............. 35 Natural Uranium

12 Analysis of Variance of Urine Matrix Comparison ............. 36

13 Urine Matrices Comparison Testing ..................... 36

14 Third-Party Crosscheck of Spiked Artificial Urine Samples ....... 38 


\section{$\underline{\text { INTRODUCTION }}$}

In recent years, extensive research has been conducted at the Pacific Northwest Laboratory (PNL) ${ }^{(a)}$ to improve occupational radiation protection. Emphasis has been placed on improving methods for detecting and characterizing radiation sources to which workers may be exposed. Of particular concern has been the accuracy of personnel dosimeters, radiation survey instruments, and bioassay laboratory measurements. The performance testing of personnel dosimetry services in support of American National Standards Institute (ANSI) Standard N13.11 (ANSI 1983) has been the subject of several research projects at PNL and other laboratories (Yoder et al. 1979; Plato and Hudson 1980; Plato and Miklos 1983; Roberson and Holbrook 1984). Technical evaluations of the capability of radiation protection survey instrumentation to meet the performance specifications of the $1984 \mathrm{draft}$ ANSI Standard $\mathrm{N} 42.17^{(\mathrm{b})}$ were jointly sponsored by the U.S. Department of Energy (DOE) and the Nuclear Regulatory Commission (NRC) (Selby et al. 1983; Swinth et al. 1983; Kenoyer et al. 1983). Bioassay measurements were first addressed in the Pilot Study Report for this program (Robinson, Fisher, and Hadley 1984) and are further discussed in this report. The studies described here were conducted to evaluate the appropriateness of draft ANSI Standard N13.30(C) for accreditation of DOE and DOEcontractor radiobioassay laboratories.

\section{QUALITY OF RADIOBIOASSAY MEASUREMENTS}

Radiobioassay procedures are used to estimate the amount of radionuclides inside the body. In vitro analysis, one type of bioassay procedure, involves measuring radioactivity in samples of body excreta. In vivo analysis involves measuring radioactive emissions from the body ( $x$ - or gamma

\footnotetext{
(a) PNL is operated for the U.S. Department of Energy by Battelle Memorial Institute under Contract DE-AC06-76RLO 1830.

(b) Information on draft ANSI Standard N42.17 is available from J. M. Selby, Pacific Northwest Laboratory, Richland, WA 99352.

(c) Information on draft ANSI Standard N13.30 is available from Roscoe Hall, E. I - duPont De Nemours \& Co., Savannah River Plant, Aiken, SC 29801.
} 
rays) using radiation detectors close to the body. Accurate bioassay measurements are necessary to assess a worker's internal dose followi'ng an intake of radioactivity.

Significant differences exist in the analytic techniques used for bioassay and in the varied physical/chemical forms of radionuclides measured. However, any effectively managed bioassay program will be concerned with quality control, so that accurate determinations are made without bias due to chemical form of the material or analytical procedure used to make the measurement.

The Health Physics Society (HPS) Working Group 2.5 (a) was formed in 1979 to address the concern for accurate measurements. This group prepared a draft standard of analytical measurement performance for radiobioassay laboratories, draft ANSI Standard N13.30, "Performance Criteria for Radiobioassay."

The primary concern of the Working Group was that bioassay service laboratories, both commercial and private (or institutional), may not be providing accurate results for analyses performed. The foll'owing factors may contribute to analytical inaccuracies:

- Analytical procedures may not be adequate.

- Each laboratory usually has its own approach to analytical procedures; methods or performance criteria common to all laboratories are lacking.

- There may be little motivation to upgrade and improve analytical capabilities.

- Adequate instrumentation is expensive; therefore, analyses may be performed with inadequate instrumentation.

- Quality assurance (QA) may be deficient (e.g., no written procedures).

(a) The current chairman of Health Physics Society Working Group 2.5 is Roscoe Hall, E. I - duPont de Nemours \& Co., Savannah River Plant, Aiken, SC 29801. 
The draft standard specifies numerical values by nuclide for acceptable minimum detectable amounts (AMDAs), relative bias $\left(B_{r}\right)$, and relative precisior required $\left(S_{A}, S_{B}\right)$. The current draft standard remains a working document of the Health Physics Society and was not formally adopted by ANSI as of January 1988.

The draft standard also includes guidelines to be used by future accrediting laboratories to test whether bioassay service laboratories conform to the quantitative performance criteria for bias and precision as well as to standard quality control procedures such as might be required in a test for laboratory accreditation.

\section{PROJECT PURPOSE}

The purpose of this project, "Technical Evaluation of Draft ANSI Standard N13.30 'Performance Criteria for Radiobioassay'," was to evaluate the appropriateness of the draft ANSI standard by conducting a bioassay performance intercomparison study. At completion of the first draft standard, the following seven objectives of the project were formulated:

- establish test procedures for evaluating bioassay laboratories in accordance with the draft standard

- set up the necessary laboratory equipment and facilities to conduct preliminary testing of bioassay laboratory performance

- conduct two rounds of intercomparison testing

- compile results and compare the performance of bioassay laboratories to the draft standard performance criteria

- analyze the data to determine sources of error

- recommend any necessary revisions to the draft standard

- prepare a procedures manual for a laboratory to follow in conducting an ongoing performance-testing program for bioassay laboratory accreditation. 
This research project involved three major phases: 1) develop testing procedures and establish laboratory facilities for preparing test samples and in vivo phantoms; 2) conduct a pilot intercomparison study with a small number of voluntarily participating in vitro and in vivo laboratories; and 3) conduct a second-round intercomparison study with a larger number of participating laboratories. A procedures manual and a research program final report were included in the third phase.

The in vitro results are presented in this report, and the remainder of the report includes a description of the two rounds of in vitro testing, a discussion of the results of those rounds, and recommendations for future revisions of draft ANSI Standard N13.30. 


\section{METHODS AND PROCEDURES}

Round One of in vitro testing was conducted by the Pacific Northwest Laboratory (PNL) using a group of volunteer bioassay laboratories. Samples of artificial urine containing radionuclides were sent by PNL to the participating laboratories along with instructions for handling samples and reporting analysis data; PNL also conducted a survey of the laboratories' estimates of minimum detectable amount (MDA) and propagated error. Round Two testing involved a larger number of laboratories and additional test radionuclides.

\section{LABORATORY PARTICIPATION}

Invitations to participate in both rounds of testing were mailed to 40 bioassay laboratories. A response form was provided with each invitation and included the following information: participation would be entirely voluntary; all costs pertaining to the measurement of samples would be borne by the participating laboratory; and confidentiality of the laboratory names, their categories of participation, and results of testing would be strictly maintained to allow uninhibited participation.

$0 f$ the 40 laboratories initially invited to participate, 25 (62\%) returned response forms. Four laboratories had no interest in participating. Twenty-one laboratories indicated a desire to be included in both rounds of testing. Subsequent to the initial invitation, 24 additional laboratories requested to participate and were included. As a result of this selection process, the participating laboratories may not constitute a representative sample of al1 bioassay service laboratories because only those laboratories most concerned with quality assurance and analytical performance may have volunteered.

\section{ROND ONE PILOT STUDY}

Five measurement categories were offered for Round One testing:

liquid scintillation counting for ${ }^{3} \mathrm{H}$

- alpha spectrometry for mixed ${ }^{241} \mathrm{Am}+{ }^{238} \mathrm{Pu}$

- beta measurements for ${ }^{90} \mathrm{Sr}$ 
- mass determination for natural uranium ( ${ }^{\text {nat }}{ }_{U}$ )

- gamma spectrometry for ${ }^{137} \mathrm{Cs}$.

The radionuclides for these categories were selected from the list of radionuclides in the draft standard. The selection of test radionuclides was based on considerations regarding their relative importance for internal dosimetry, frequency of need for bioassay services, and the judgment of project staff members. Ideally, a laboratory would have the opportunity to be tested with each radionuclide of a particular category. In general, responding bioassay laboratories were most interested in participating in all categories in which they normally process samples.

The first-round intercomparison study was limited to 9, from a total of 17 , participating laboratories per category. Participants were matched to categories of interest, and telephone calls were then made to confirm participation and to indicate the schedule for shipping samples. Because of the large number of willing participants, the participation of each bioassay laboratory was limited to a maximum of four test categories. Round One included 17 participating laboratories: 5 in one category, 5 in two categories, 5 in three categories, and 2 in four categories.

\section{ROUND TMO TESTING}

The following measurement categories were included in the second round of in vitro testing:

- Iiquid scintillation counting for ${ }^{3} \mathrm{H}$

- alpha spectrometry for mixed ${ }^{241} \mathrm{Am}+{ }^{238} \mathrm{Pu}$

- beta measurement for mixed ${ }^{89} \mathrm{Sr}+{ }^{90} \mathrm{Sr}$

- mass determination for natural uranium $\left({ }^{n a t} t_{U}\right)$

- gamma spectrometry for mixed ${ }^{60} \mathrm{Co}+{ }^{137} \mathrm{Cs}$.

Values for relative bias, relative precision, and MDA were calculated for a total of 35 laboratories in Round Two testing. Round Two resulted in 14 labs being evaluated in only one category, 9 in two categories, 8 in three categories, 1 in four categories, and 3 in five categories. Not all of these labs returned data for both test nuclides in a category, and some laboratories returned inadequate data for calculating values for all criteria. 
SURVEY OF MINIMUM DETECTABLE ANOUNT AND ESTIMATED ANALYTICAL ERROR

The MDA is an indicator of the detection capability of a laboratory's analytical method. A survey of participating in vitro laboratories was taken before the test samples were prepared for Round One (a sample letter is shown in Appendix A). The laboratories were asked to provide an estimate of their MDA using the formula recommended by the draft standard and using estimated parameters (or average historical parameters, if available). The survey of participating laboratories also included a request for an estimate of propagated errors at various analytical levels. The analytical levels chosen were multiples of the AMDA levels set forth in the draft standard for each nuclide.

\section{PREPARATION OF IN VITRO TEST SAMPLES}

Under an interagency agreement between the National Bureau of Standards (NBS) of the U.S. Department of Commerce and the NRC, NBS prepared and provided calibrated, standardized radioactive stock solutions for this project. The radionuclides listed in Table 1 were obtained from NBS in heat-sealed glass ampules.

TABLE 1. Chemical Form(s) of Radionuclides Supplied by the National Bureau of Standards

$\frac{\text { Nucl ide }}{{ }^{3} \mathrm{H}}$
${ }^{238} \mathrm{Pu}$
${ }^{241} \mathrm{Am}$
${ }^{89} \mathrm{Sr}$
${ }^{90} \mathrm{Sr}$
${ }^{{ }^{2 a t}} \mathrm{U}$
${ }^{60} \mathrm{Co}$
${ }^{137} \mathrm{Cs}$

Chemical Form

Tritiated water

Plutonium nitrate in $5 \mathrm{M} \mathrm{nitric} \mathrm{acid}$ Americium nitrate in $1 \mathrm{M}$ nitric acid Strontium chloride in $1 \mathrm{M}$ hydrochloric acid Strontium chloride in $1 \mathrm{M}$ hydrochloric acid Uranium nitrate in $1 \mathrm{M}$ nitric acid Cobalt chloride in $2 \mathrm{M}$ hydrochloric acid Cesium chloride in $1 \mathrm{M}$ hydrochloric acid 
Table 2 shows the measurement testing categories, radionuclides, and testing levels chosen for both rounds of testing. The testing levels shown in Table 2 for Round One correspond to the testing ranges recommended in the June 1983 draft standard. For Round Two, the January $1984 \mathrm{draft}$ standard was used. Certification and documentation accompanied each radionuclide preparation supplied by NBS. In addition, NBS radiochemists visited PNL, reviewed and audited proposed procedures for diluting the radionuclides into artificial urine test samples, and provided recommendations for improved accuracy in the preparation of test samples. Their recommendations were incorporated into the procedures (see Appendix B). This direct and frequent collaboration between PNL and NBS resulted in an increased level of confidence in the accuracy of radionuclide levels in samples prepared for the intercomparison testing.

Test samples consisted of an artificial urine matrix spiked with precisely controlled amounts of radionuclide. Artificial urine was selected over natural human urine because it is easily manufactured in the laboratory from commercially available chemicals and can be mixed in any amount. Artificial urine is chemically stable, has a long shelf-life, and requires no preservation. In contrast, natural human urine is chemically and biologically active and, therefore, decomposes rapidly with time unless stabilized. Because artificial urine can be readily prepared as needed, its cost is

TABLE 2. In Vitro Testing Categories, Radionuclides, and Testing Levels

\begin{tabular}{|c|c|c|c|c|}
\hline Testing Category & Nuclide & Round One & Round Two & Units \\
\hline Liquid Scintillation & $3_{H}$ & $\begin{array}{l}0,0.03,0.30, \\
3.54\end{array}$ & $\begin{array}{l}0,0.01,0.15 \\
1.5\end{array}$ & $\mu \mathrm{Ci} / \mathrm{L}$ \\
\hline Alpha Spectrometry & $\begin{array}{l}238 \mathrm{Pu} \\
241_{\mathrm{Am}}\end{array}$ & $\begin{array}{lll}0, & 0.11, & 0.93 \\
0, & 0.09, & 0.91\end{array}$ & $\begin{array}{lll}0, & 0.18, & 0.72 \\
0, & 0.19, & 0.75\end{array}$ & $\begin{array}{l}\mathrm{pCi} / \mathrm{L} \\
\mathrm{pCi} / \mathrm{L}\end{array}$ \\
\hline Beta Measurements & $\begin{array}{l}{ }^{89} \mathrm{Sr} \\
{ }^{4} \mathrm{Sr}\end{array}$ & $0, \quad 16.9,{ }^{--} 185$ & $\begin{array}{lll}0, & 36.9, & 108 \\
0, & 45.7, & 124\end{array}$ & $\begin{array}{l}\mathrm{pCi} / \mathrm{L} \\
\mathrm{pCi} i / \mathrm{L}\end{array}$ \\
\hline Mass Determination & nat $_{U}$ & $0, \quad 7.2, \quad 78$ & $0, \quad 0.21$ & $\mu \mathrm{g} / \mathrm{L}$ \\
\hline Germa Spectrometry & ${ }_{137}^{60} \mathrm{Co}$ & $0, \quad 1.5, \overline{13.8}$ & $\begin{array}{lll}0, & 16.7, & 52.1 \\
0, & .25, & 1.2\end{array}$ & $\begin{array}{l}n C i / L \\
n C i / L\end{array}$ \\
\hline
\end{tabular}


considerably less than the cost of obtaining and storing natural urine. In addition, natural urine may be highly variable in composition from one donor to another, whereas artificial urine is more uniform in composition. Finally, the background radioactivity of artificial urine is more easily controlled than that of natural urine. For testing purposes, artificial urine was the matrix of choice.

The recipe adopted for artificial urine (see Table 3) was a composite from several sources (Free and Free 1978; Attman and Dittmer 1968; Long 1961; Doresmus, Terch, and Silvis 1978; Kelsay, Beha11, and Prather 1979; Burns and Finlayson 1980; Lentner 1981) and included major urine components in physiological quantities.

The artificial urine was prepared in 50-L batches according to the recipe given in Table 3. Each concentration of radionuclide was prepared as follows: artificial urine was placed in a $50-L$ polyethylene carboy containing a 6 - by , I-in. magnetic stirring bar. The carboy containing urine was placed on a magnetic stirrer and stirred thoroughly. The correct volume of spike was then added. The spiked urine was stirred for 30 minutes, and appropriate volumes

\section{TABLE 3. Artificial Urine Recipe}

\begin{tabular}{|c|c|c|c|}
\hline Component & $\mathrm{g} / \mathrm{kg}$ & Component & $\mathrm{g} / \mathrm{kg}$ \\
\hline Urea & 16.0 & Anhydrous Sodium Dihydrogen & 2.73 \\
\hline Sodium Chloride & 2.32 & Phosphate & \\
\hline Potassium Chloride & 3.43 & Anhydrous Calcium Chloride & 0.63 \\
\hline Creatinine & 1.10 & Oxalic Acid & 0.02 \\
\hline Anhydrous Sodium Sulfate & 4.31 & Lactic Acid & 0.094 \\
\hline Hippuric acid & 0.63 & Glucose & 0.48 \\
\hline Ammonium Chloride & 1.06 & Anhydrous Sodium Silicate(a) & 0.071 \\
\hline Citric acid & 0.54 & Pepsin & 0.029 \\
\hline Anhydrous Magnesium Sulfate & 0.46 & Conc. Nitric Acid (70\%)(b) & 50.0 \\
\hline & & Yellow Food Coloring & 0.06 \\
\hline
\end{tabular}

(a) $7 \mathrm{mg} \mathrm{Si/kg}$ urine.

(b) Added to ensure spiked radionuclides remained in ionic form. 
(usually 1.4-L) were dispensed into preweighed and prelabeled (usually 2-L) plastic bottles. The bottles were then reweighed. Bottles were randomly divided into lots of three each by drawing numbered tokens from a container.

For each test category except that of liquid scintillation, each participating laboratory received nine 1.4-L samples. Three of these samples were control urine samples that had not been spiked with radioactive materials; three were spiked at the lower testing level shown in Table 2; and three were spiked at the higher testing level.

For liquid scintillation counting, tritium $\left({ }^{3} \mathrm{H}\right)$ samples were supplind in 100- to $150-\mathrm{mL}$ volumes. Nine samples were prepared as above, and three additional samples were sent with tritium levels at the middle spiked testing level indicated in Table 2. The three extra samples were prepared anticipating that the testing range for tritium might be lowered by the group preparing the standard, and that results for this range would provide important data.

Complete step-by-step sample preparation procedures are provided in Appendix B of this report. The suitability of artificial urine was tested by parallel analyses of equally spiked artificial and natural urine samples. The conclusions are described in the "results" section of this report.

\section{ARTIFICIAL URINE SAMPLE IDENTIFICATION AND SHIPMENT TO PARTICIPATING}

\section{LABORATORIES}

The filled bottles were labeled as shown in Figure 1. An identification code of the form A-2Sr9-0021-7631-32 was used where:

$$
\begin{aligned}
\mathrm{A} & =\text { laboratory identification code } \\
2 & =\text { round number, } 1 \text { or } 2 \\
\mathrm{Sr} 9 & ={ }^{89} \mathrm{Sr}, \text { SrO }={ }^{90} \mathrm{Sr}, \mathrm{Cs} 7={ }^{137} \mathrm{Cs}, \text { etc } . \\
0021 & =\text { sample number from } 0001 \text { to } 9999 \\
7631 & =\text { PNL laboratory book identification number } \\
32 & =\text { PNL laboratory book page number }
\end{aligned}
$$




\section{RADIOACTIVE}

Sample A-2Sr9-0021-7631-32

$7 / 8 / 82$

Pacific Northwest Laboratory

$3746 \mathrm{~A} / 300$ Area

Richland, 99352

$(<100 \mathrm{pCi} / \mathrm{L})$

509-375-2065, AL

FIGURE 1. Sample Label for Artificial Urine Sample Bottles

Each bottle was labeled with PNL's address, date of the spike, the telephone number of a cognizant PNL staff member, and the word "RADIOACTIVE" (see Figure 1). The cap of each sample bottle was sealed with vinyl tape, the bottle was packed in a nest of absorbent material, and then three bottles were packed in each box.

Shiobina regulations did not reauire anv external radiation labeling of the box. The activity levels qualified under a "limited quantity" designation, and the packing and labeling complied with federal regulations for packaging and shipping nonradioactive materials. All samples were shipped by surface carrier.

Each participant received a letter under separate cover advising of the forthcoming samples. In addition, several enclosures accompanied the package when it was sent to the participating laboratory, including:

- general instructions and explanations

- quality assurance guidelines

- an In Vitro Measurements Report Form.

The general instructions contained procedures for logging in samples and confirming their receipt, a request for analytical procedures used, and a deadline for reporting data. A sample of the instructions to participating laboratories is included in Appendix $\mathrm{C}$ of this report. A copy of the In Vitro Measurements Report Form is included in Appendix D. 


\section{QUALITY ASSURANCE PLAN}

This research project conformed with PNL-MA-65 (Fuquay 1978) and with the draft ANSI Standard N13.30, "Performance Criteria for Radiobioassay." As the testing laboratory, PNL was bound by the same QA requirements as the participating laboratories.

A t PNL, all equipment and laboratory procedures or evaluations were documented in laboratory notebooks and records books. Standard reference materials were obtained from NBS and were used for all spikes.

Quality Assurance For Participating Laboratories

Participating laboratories were guided by QA instructions presented in Section 5 of the draft standard. Pacific Northwest Laboratory specifically addressed Section 5.1.1 (Parts B, D, E, and F) in our Instructions to Laboratories (Appendix $\mathrm{C}$ ) and in the In Vitro Measurements Report Form (Appendix D). Third-Party Crosscheck of Samples

Sample preparation involved mixing large batches of artificial urine with small volumes of radionuclide. It was possible, therefore, for problems of absorption, incomplete mixing, precipitation, and cross-contamination to occur, which could have resulted in test samples not receiving the specified radionuclide amounts. Although the sample preparation procedures were designed to prevent these occurrences, some form of crosscheck on the final solution was desirable. Therefore, an aliquant ${ }^{(a)}$ was taken from each batch and submitted to a third-party analytical laboratory for crosscheck analysis. (b) The third-party laboratory was required to be implicitly traceable to NBS. Special handling and nonroutine analyses were also requested of the third-party laboratory to ensure accurate measurements.

\footnotetext{
(a) An "aliquant" is a part of the whole that divides it and leaves a remainder. This is not to be confused with "aliquot." An "aliquot" is a part of the whole that divides it and leaves no remainder, i.e., is contained an exact number of times in that which is being divided."

(b) Performed by TMA/Norca1, Richmond, California.
} 


\section{RESULTS}

The following section describes laboratory results from Round One and Round Two testing. Results of the comparison between natural and artificial urine are then evaluated. Finally, the third-party crosscheck analysis results are described and compared with radionuclide concentrations.

\section{LABORATORY PERFORMANCE}

Table 4 summarizes the percentages of laboratories reporting measurement results. For Round One, 356 measurement results were received from 17 in vitro laboratories. An additional 157 samples were sent out, for which no results were received. Nonreporting laboratories were contacted at least twice regarding the need for measurement results. In Round Two, 1038 results (of a possible 1680) were received from 35 laboratories.

The data received from the participating in vitro bioassay laboratories included background count rates and counting times. The reported test data were tabulated and treated by the statistical methods described in the draft standard and in Appendix F.

The measurement results for each test category and laboratory are presented in Appendix $G$. Appendix $G$ also includes the true activity concentration (nuclide added to the artificial urine), the calculated bias and precision estimators, the laboratory MDA, and an indication of the laboratory's

\section{TABLE 4. Percentage of Participating Laboratories} that Reported Test Results

\begin{tabular}{clc}
$\frac{\text { Nuclide }}{{ }^{3} \mathrm{H}}$ & \multicolumn{1}{c}{ Test Category } & $\begin{array}{c}\text { Responding } \\
\text { Laboratories, \% }\end{array}$ \\
${ }^{238_{\mathrm{Pu}}}$ & Alphaid scintillation spectrometry & 89 \\
${ }^{241} \mathrm{Am}$ & Alpha spectrometry & 56 \\
& Beta counting & 56 \\
${ }^{n a t} \mathrm{U}$ & Mass determination & 56 \\
${ }^{137} \mathrm{Cs}$ & Gamma spectrometry & 78 \\
& & 89
\end{tabular}


ability to meet the performance criteria of the draft standard. The acceptance values were:

- $\mathrm{MDA} \leqq \mathrm{AMDA}$

- $-0.25 \leqq \mathrm{~B}_{\mathrm{r}} \leqq 0.50$

- $\mathrm{S}_{\mathrm{A}}$ and $\mathrm{S}_{\mathrm{B}} \leqq 0.40$.

Relative bias $\left(B_{r}\right)$ is a measure of the laboratory's average reported deviation from the "true" value or activity for a nuclide category, and $S_{A}$ and $S_{B}$ measure the reproducibility of an analysis. The relative precision estimator, $S_{A}$, measures variability around the average value of an analysis, while $S_{B}$ measures variability around the "true" value or activity. In an ongoing testing program, failure to meet any one of the above criteria for a radionuclide in a test category would result in failure for the entire test category. For this report, each radionuclide and concentration group was evaluated separately against the criteria, but only concentrations greater than 10 times the AMDA were used to determine whether the laboratory passed the standard criteria for a nuclide. For example, ${ }^{241} \mathrm{Am}$ and ${ }^{238} \mathrm{Pu}$ were both in the test category "alpha spectrometry." A laboratory that failed to analyze the low-level ${ }^{238} \mathrm{Pu}$-spiked sample did not automatically fail the high-level ${ }^{238}$ Pu-spiked sample or the ${ }^{241} \mathrm{Am}$ samples. If a high-level spiked sample failed, the laboratory failed the nuclide category regardless of the low-level results.

Table 5 provides a summary of laboratories that received samples in each test category and shows analytical performance measured against the criteria of the draft standard. Table 6 shows the percentage of in vitro measurements that did not meet the performance criteria and the reasons for failure. Again, each radionuclide was treated separately, as was each concentration level. For example, if five laboratories were each sent three replicate samples, 5 data points would result. If they were each sent two concentrations (three samples/concentration) of ${ }^{n a t} U, 10$ data points would result-each consisting of the laboratory average of the three replicates. These 10 data points would be compared to the three draft standard criteria and then scored. If two laboratories provided results for a nuclide and concentration that resulted in failure of one or more of the performance criteria, this 
TABLE 5. Summary of In Vitro Testing Results

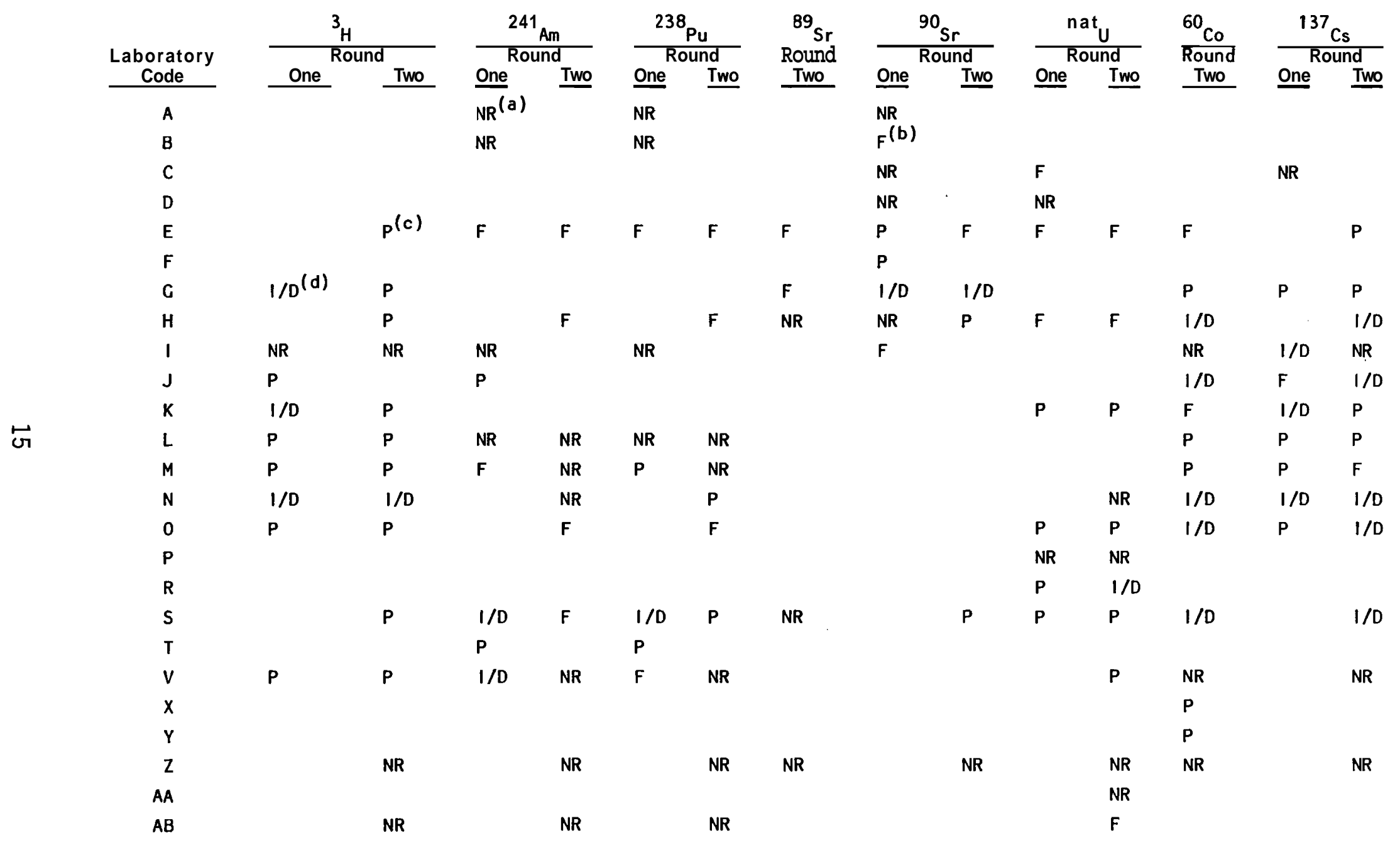

(a) $\mathrm{NR}=$ Results not returned

(b) $F=F$ ail

(d) $1 / D=$ Inadequate Data to calculate all criteria 
TABLE 5. (contd)

\begin{tabular}{|c|c|c|c|c|c|c|c|c|c|c|c|c|c|c|}
\hline \multirow{2}{*}{$\begin{array}{c}\text { Laboratory } \\
\text { Code } \\
\end{array}$} & \multicolumn{2}{|c|}{$\frac{{ }^{3} \mathrm{H}}{\text { Bound }}$} & \multicolumn{2}{|c|}{$\begin{array}{l}{ }^{241} \text { Ara } \\
\text { Round }\end{array}$} & \multicolumn{2}{|c|}{${ }^{238} \mathrm{Pu}$} & \multirow{2}{*}{$\begin{array}{l}{ }^{89} \mathrm{Sr} \\
\text { Round } \\
\text { Two } \\
\end{array}$} & \multicolumn{2}{|c|}{${ }^{90} \mathrm{Sr}$} & \multicolumn{2}{|c|}{${ }^{n^{\prime}{ }_{u}}$} & \multirow{2}{*}{$\begin{array}{l}60 \\
{ }^{60} \text { Co } \\
\text { Round } \\
\text { Two } \\
\end{array}$} & \multicolumn{2}{|c|}{$\frac{{ }^{137} \mathrm{Cs}}{\text { Round }}$} \\
\hline & One & Two & One & Two & One & Two & & One & Two & One & Two & & One & Two \\
\hline$A C$ & & & & & & & & & & & $F$ & & & \\
\hline$A D$ & & $P$ & & NR & & NR & NR & & NR & & $F$ & $1 / 0$ & & I/D \\
\hline$A E$ & & $P$ & & & & & NR & & NR & & NR & $1 / 0$ & & $1 / D$ \\
\hline AF & & NR & & & & & NR & & NR & & NR & NR & & NR \\
\hline$A G$ & & $P$ & & NR & & NR & & & & & $F$ & $F$ & & $F$ \\
\hline AH & & $P$ & & & & & & & & & $1 / 0$ & NR & & NR \\
\hline Al & & $F$ & & & & & NR & & $1 / D$ & & & $1 / 0$ & & $1 / D$ \\
\hline AJ & & $P$ & & NR & & NR & $F$ & & $\mathbf{P}$ & & & $F$ & & $F$ \\
\hline AK & & & & & & & NR & & $\mathrm{NR}$ & & & & & \\
\hline $\mathrm{AL}$ & & $P$ & & & & & NR & & NR & & & NR & & NR \\
\hline AM & & $P$ & & & & & $F$ & & $P$ & & & $1 / D$ & & $1 / D$ \\
\hline AN & & $P$ & & NR & & NR & $F$ & & $1 / 0$ & & & $1 / 0$ & & $1 / D$ \\
\hline AO & & NR & & & & & NR & & NR & & & NR & & NR \\
\hline AP & & NR & & NR & & $F$ & $P$ & & $P$ & & & NR & & NR \\
\hline$A Q$ & & $P$ & & & & & NR & & NR & & $P$ & & & \\
\hline AU & & $P$ & & & & & & & & & & $F$ & & $\mathrm{~F}$ \\
\hline AV & & $P$ & & & & & & & & & & NR & & NR \\
\hline BA & & $\mathbf{P}$ & & & & & & & & & & & & \\
\hline BB & & $1 / D$ & & & & & & & & & & & & \\
\hline$B C$ & & $I / D$ & & & & & & & & & & & & \\
\hline BD & & $\mathbf{P}$ & & & & & & & & & & & & \\
\hline $\mathrm{BE}$ & & $\mathbf{P}$ & & & & & & & & & & & & \\
\hline BF & & NR & & NR & & NR & & & & & & $1 / D$ & & $1 / 0$ \\
\hline$B G$ & & & & & & & & & & & & NR & & NR \\
\hline
\end{tabular}

(a) $\mathbf{N R}=$ Results not returned

(b) $F=F a i l$

(c) $P=$ Pass
(d) $I / D=$ Inadequate Data to calculate all criteria 
TABLE 6 In Vitro Testing Results by Nuclide Category

\begin{tabular}{|c|c|c|c|c|c|c|c|c|c|c|c|c|c|}
\hline \multirow[b]{2}{*}{ Nuclide } & \multirow[b]{2}{*}{$\operatorname{AMDA}^{(\mathrm{a})}$} & \multirow[b]{2}{*}{ Round } & \multirow{2}{*}{$\begin{array}{c}\text { No. of } \\
\text { Partici- } \\
\text { pants } \\
\end{array}$} & \multirow[b]{2}{*}{$\begin{array}{c}\text { Test }^{(a)} \\
\text { Level } \\
\end{array}$} & \multicolumn{6}{|c|}{ Number of Failures } & \multicolumn{3}{|c|}{ Category Results $(\%)$} \\
\hline & & & & & Bias & $\begin{array}{l}\text { Bias \& } \\
\text { Precision }\end{array}$ & $M \mathrm{MA}^{(b)}$ & $\begin{array}{l}\text { MDA } \\
\& \text { Bias } \\
\end{array}$ & $\begin{array}{c}\text { MDA \& } \\
\text { Precision }\end{array}$ & $\begin{array}{l}\text { Precision } \\
\text { Bias \& MDA }\end{array}$ & Pass & Fail & $1 / D^{(c)}$ \\
\hline $3_{H}$ & 100 & 1 & 8 & $\begin{array}{c}29.5 \\
301 \\
3540\end{array}$ & $\begin{array}{l}0 \\
0 \\
0\end{array}$ & $\begin{array}{l}0 \\
0 \\
0\end{array}$ & $\begin{array}{l}0 \\
0 \\
0\end{array}$ & $\begin{array}{l}0 \\
0 \\
0\end{array}$ & $\begin{array}{l}0 \\
0 \\
0\end{array}$ & $\begin{array}{l}0 \\
0 \\
0\end{array}$ & $\begin{array}{l}50 \\
63 \\
63\end{array}$ & $\begin{array}{l}0 \\
0 \\
0\end{array}$ & $\begin{array}{l}50 \\
38 \\
38\end{array}$ \\
\hline & 100 & 2 & 28 & $\begin{array}{c}11-1 \\
154 \\
1490\end{array}$ & $\begin{array}{l}4 \\
0 \\
1\end{array}$ & $\begin{array}{l}2 \\
0 \\
0\end{array}$ & $\begin{array}{l}0 \\
0 \\
0\end{array}$ & $\begin{array}{l}0 \\
0 \\
0\end{array}$ & $\begin{array}{l}0 \\
0 \\
0\end{array}$ & $\begin{array}{l}0 \\
0 \\
0\end{array}$ & $\begin{array}{l}71 \\
89 \\
86\end{array}$ & $\begin{array}{r}21 \\
0 \\
4\end{array}$ & $\begin{array}{r}7 \\
11 \\
11\end{array}$ \\
\hline \multirow{3}{*}{${ }^{90} \mathrm{Sr}$} & 10 & 2 & 6 & $\begin{array}{c}36.9 \\
108\end{array}$ & $\begin{array}{l}1 \\
1\end{array}$ & $\begin{array}{l}0 \\
0\end{array}$ & $\begin{array}{l}1 \\
1\end{array}$ & $\begin{array}{l}0 \\
1\end{array}$ & $\begin{array}{l}1 \\
1\end{array}$ & $\begin{array}{l}2 \\
1\end{array}$ & $\begin{array}{l}17 \\
17\end{array}$ & $\begin{array}{l}83 \\
83\end{array}$ & $\begin{array}{l}0 \\
0\end{array}$ \\
\hline & 10 & 1 & 5 & $\begin{array}{c}16 A \\
185\end{array}$ & $\begin{array}{l}0 \\
1\end{array}$ & $\begin{array}{l}0 \\
0\end{array}$ & $\begin{array}{l}1 \\
1\end{array}$ & $\begin{array}{l}0 \\
0\end{array}$ & $\begin{array}{l}0 \\
0\end{array}$ & $\begin{array}{l}0 \\
0\end{array}$ & $\begin{array}{l}60 \\
40\end{array}$ & $\begin{array}{l}20 \\
40\end{array}$ & $\begin{array}{l}20 \\
20\end{array}$ \\
\hline & 10 & 2 & 9 & $\begin{array}{c}45 \cdot 9 \\
124\end{array}$ & $\begin{array}{l}1 \\
1\end{array}$ & $\begin{array}{l}0 \\
0\end{array}$ & $\begin{array}{l}0 \\
0\end{array}$ & $\begin{array}{l}0 \\
0\end{array}$ & $\begin{array}{l}0 \\
0\end{array}$ & $\begin{array}{l}0 \\
0\end{array}$ & $\begin{array}{l}56 \\
56\end{array}$ & $\begin{array}{l}11 \\
11\end{array}$ & $\begin{array}{l}33 \\
33\end{array}$ \\
\hline \multirow[t]{2}{*}{${ }^{238} \mathrm{Pu}$} & $0.0 \Sigma$ & 1 & 5 & $\begin{array}{l}0.107 \\
0.928\end{array}$ & $\begin{array}{l}0 \\
0\end{array}$ & $\begin{array}{l}1 \\
0\end{array}$ & $\begin{array}{l}1 \\
2\end{array}$ & $\begin{array}{l}0 \\
0\end{array}$ & $\begin{array}{l}0 \\
0\end{array}$ & $\begin{array}{l}1 \\
0\end{array}$ & $\begin{array}{l}20 \\
40\end{array}$ & $\begin{array}{l}60 \\
40\end{array}$ & $\begin{array}{l}20 \\
20\end{array}$ \\
\hline & $0.0 \leftleftarrows$ & 2 & 6 & $\begin{array}{l}0.7^{\mathrm{m} 2} \\
0.7 \mathrm{z}^{2}\end{array}$ & $\begin{array}{l}0 \\
0\end{array}$ & $\begin{array}{l}0 \\
0\end{array}$ & $\begin{array}{l}4 \\
4\end{array}$ & $\begin{array}{l}0 \\
0\end{array}$ & $\begin{array}{l}0 \\
0\end{array}$ & $\begin{array}{l}0 \\
0\end{array}$ & $\begin{array}{l}33 \\
33\end{array}$ & $\begin{array}{l}67 \\
67\end{array}$ & $\begin{array}{l}0 \\
0\end{array}$ \\
\hline${ }^{241} \mathrm{Am}$ & $0.0 \Sigma$ & 1 & 5 & $\begin{array}{l}0.083 \\
0.91\end{array}$ & $\begin{array}{l}0 \\
0\end{array}$ & $\begin{array}{l}1 \\
0\end{array}$ & $\begin{array}{l}1 \\
2\end{array}$ & $\begin{array}{l}0 \\
0\end{array}$ & $\begin{array}{l}1 \\
0\end{array}$ & $\begin{array}{l}0 \\
0\end{array}$ & $\begin{array}{r}0 \\
20\end{array}$ & $\begin{array}{l}60 \\
40\end{array}$ & $\begin{array}{l}40 \\
40\end{array}$ \\
\hline
\end{tabular}

(a) Units $=$ pci/L except ${ }^{3} \mathrm{H}=\mathrm{nCi} / \mathrm{L}$ and nat $_{U}=\mu \mathrm{g} / \mathrm{L}$.

(b) MDA-1 used for all nuclides except natural uranium and ${ }^{89} \mathrm{Sr}$ which used MDA-2 (MDA-1 and MDA-2 defined in Appendix $\mathrm{F}$ ) (c) $1 / D=$ inadequate data. 
TABLE 6. contd)

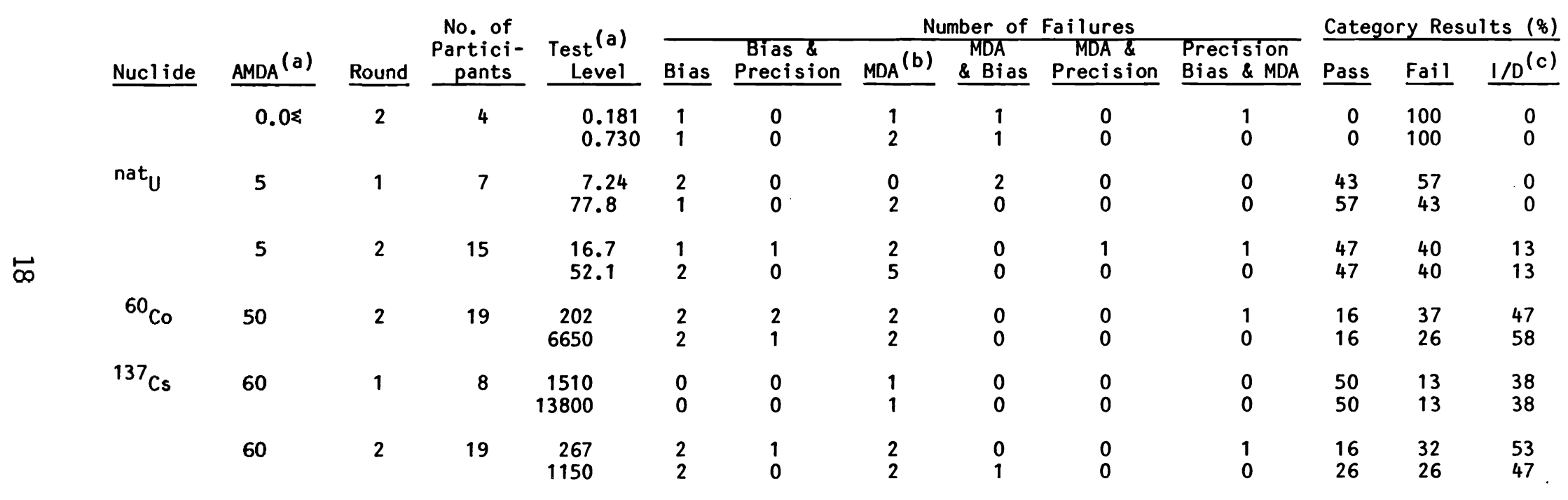

(a) Units $=$ pci/L except ${ }^{3} \mathrm{H}=\mathrm{nCi} / \mathrm{L}$ and ${ }^{\text {nat }} \mathrm{U}=\mu \mathrm{g} / \mathrm{L}$

(a) Units $=$ pci $/ \mathrm{L}$ except ${ }^{3} \mathrm{H}=\mathrm{nCi} / \mathrm{L}$ and ${ }^{\text {nat }} \mathrm{U}=\mu \mathrm{g} / \mathrm{L}$. (c) $1 / D=$ inade<uate data. 
would result in a $40 \%$ failure rate for that nuclide and concentration. The data indicate that the failure rate varied markedly from nuclide to nuclide and was quite high for several of the nuclides. Particular difficulty was noted in meeting draft standard criteria for ${ }^{89} \mathrm{Sr}$ and ${ }^{241} \mathrm{Am}$.

In Figures 2 through 9, relative bias $\left(B_{r}\right)$ versus relative precision $\left(S_{A}\right.$ and $\left.S_{B}\right)$ were plotted by nuclide for each participant. Since the draft standard specifies that $B_{r}, S_{A}$, and $S_{B}$ need to be met only at testing concentrations greater than 10 times the AMDA, only the results at those concentrations were plotted. If the average bias is negative, $S_{A}$ will be larger than $S_{B}$. If the bias is positive, the opposite will be true. If the bias is zero, $S_{A}$ and $S_{B}$ will be equal. For all categories, $B_{r}$ was much more limiting than either $S_{A}$ or $S_{B}$.

In practice, the calculated values of $S_{A}$ and $S_{B}$ were similar. For all nuclide categories except ${ }^{89} \mathrm{Sr}$, the upper bound of the 1- $\sigma$ confidence intervals for the calculated values of $S_{A}$ and $S_{B}$ varied by $20 \%$ or less. For the ${ }^{89} \mathrm{Sr}$ category (see Figure 3 ), which had a small population size of six (and one data point with a large calculated relative bias and precision), the upper bound of the $S_{A}$ interval (1.1) was twice that of the $S_{B}$ interval (0.5). In only one data point (the ${ }^{89} \mathrm{Sr}$ category) did a laboratory fail a relative precision statistic $\left(S_{A}\right)$ without also failing $B_{r}$. For three nuclides $\left({ }^{3} H\right.$, ${ }^{238} \mathrm{Pu}$, and $\left.{ }^{\text {nat }} U\right)$, the $1-\sigma$ confidence intervals for the values of $B_{r}, S_{A}$, and $S_{B}$ were completely within the acceptance regions specified by the draft standard (see Figures 2, 5, and 7). For ${ }^{90} \mathrm{Sr},{ }^{241} \mathrm{Am},{ }^{60} \mathrm{Co}$, and ${ }^{137} \mathrm{Cs}$, the confidence intervals for relative precision results were well within the acceptable range, but the $B_{r}$ interval extended beyond it (see Figures 4, 6, 8 , and 9). For all these nuclide categories, the mean values for $B_{r}, S_{A}$, and $S_{B}$ were within the acceptance region.

For the remaining nuclide category $\left({ }^{89} \mathrm{Sr}\right)$, the mean relative bias $(-0.36)$ was outside the acceptance region, but approximately one-half the mean negative bias was attributed to one data point (see Figure 3 ). If this data point were excluded from the sample, the mean values for all three criteria would be within the acceptance region--although the confidence intervals would still be at least $50 \%$ greater than for the other nuclide categories. 


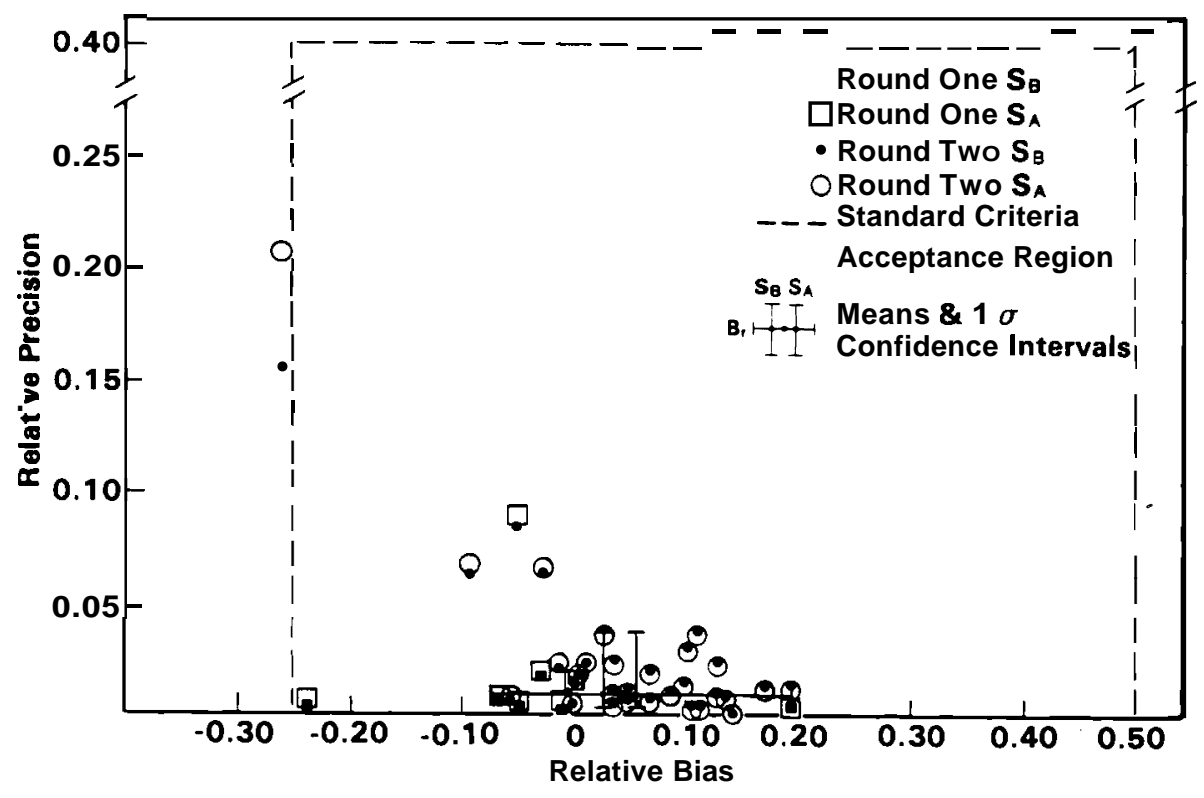

FIGURE 2. $\quad{ }^{3} \mathrm{H}$ Relative Precision and Relative Bias

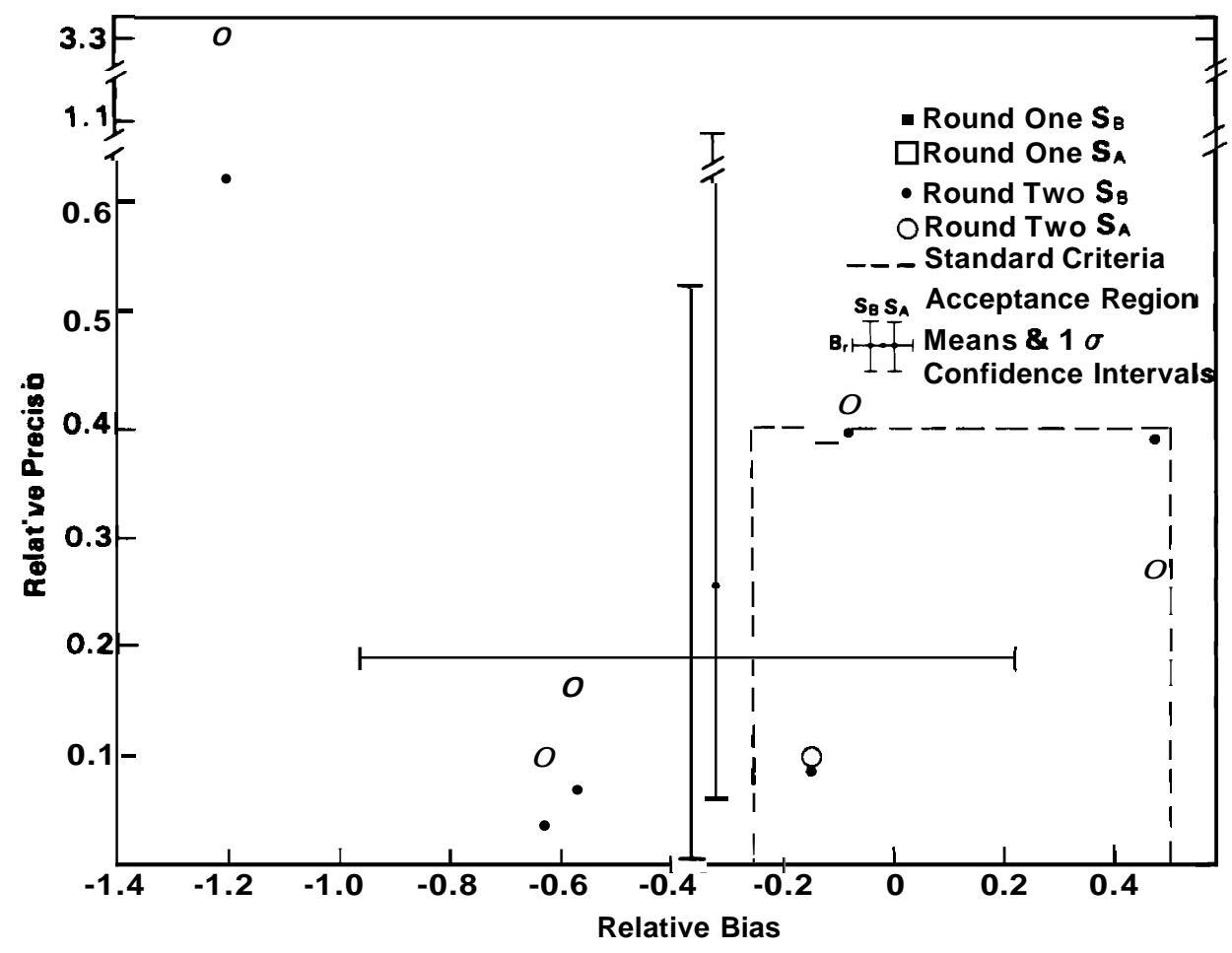

FIGURE 3. ${ }^{89}$ Sr Relative Precision and Relative Bias 


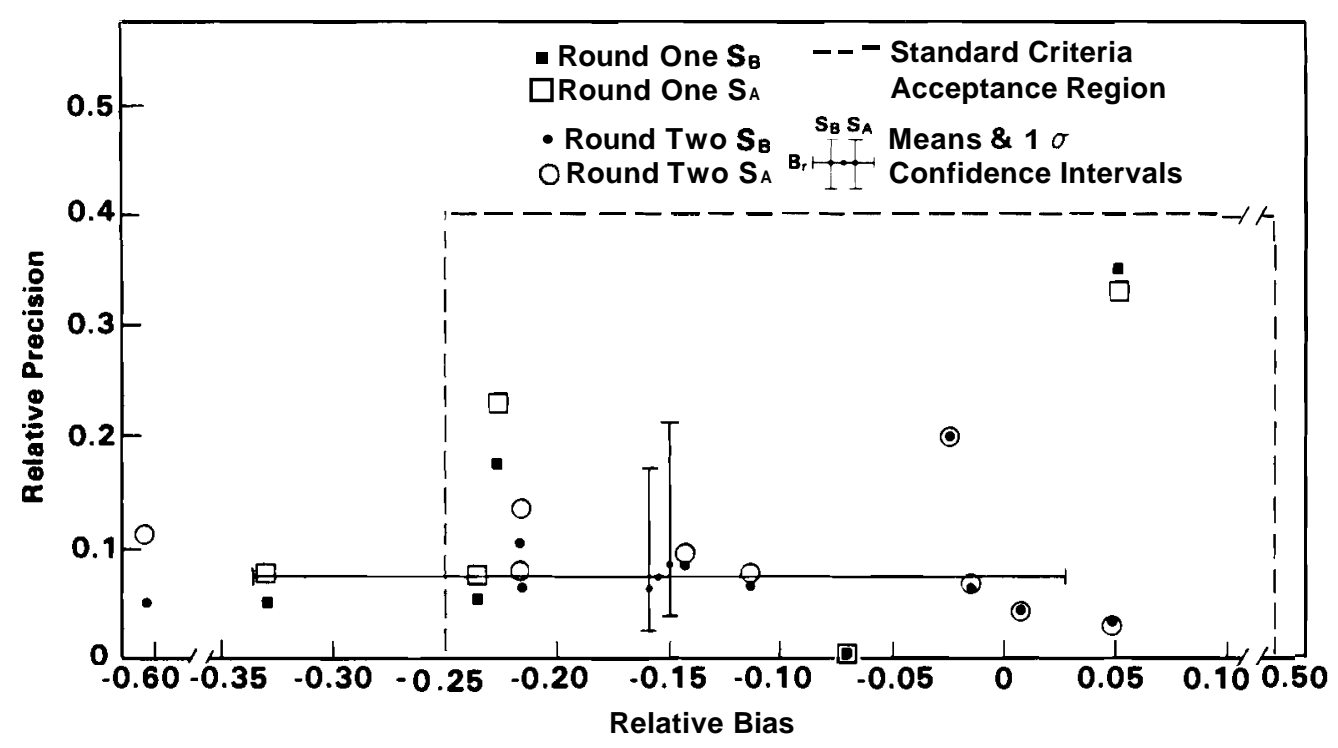

FIGURE 4. ${ }^{90}$ Sr Relative Precision and Relative Bias

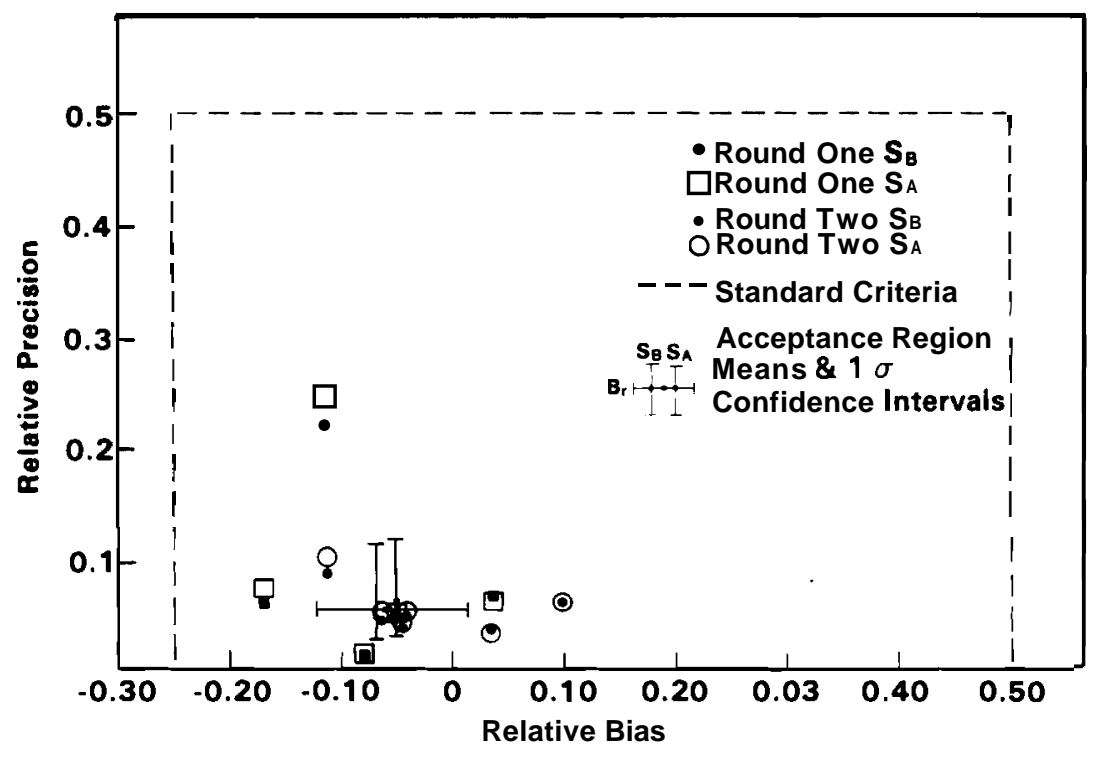

FIGURE 5. $\quad{ }^{238} \mathrm{Pu}$ Relative Precision and Relative Bias 


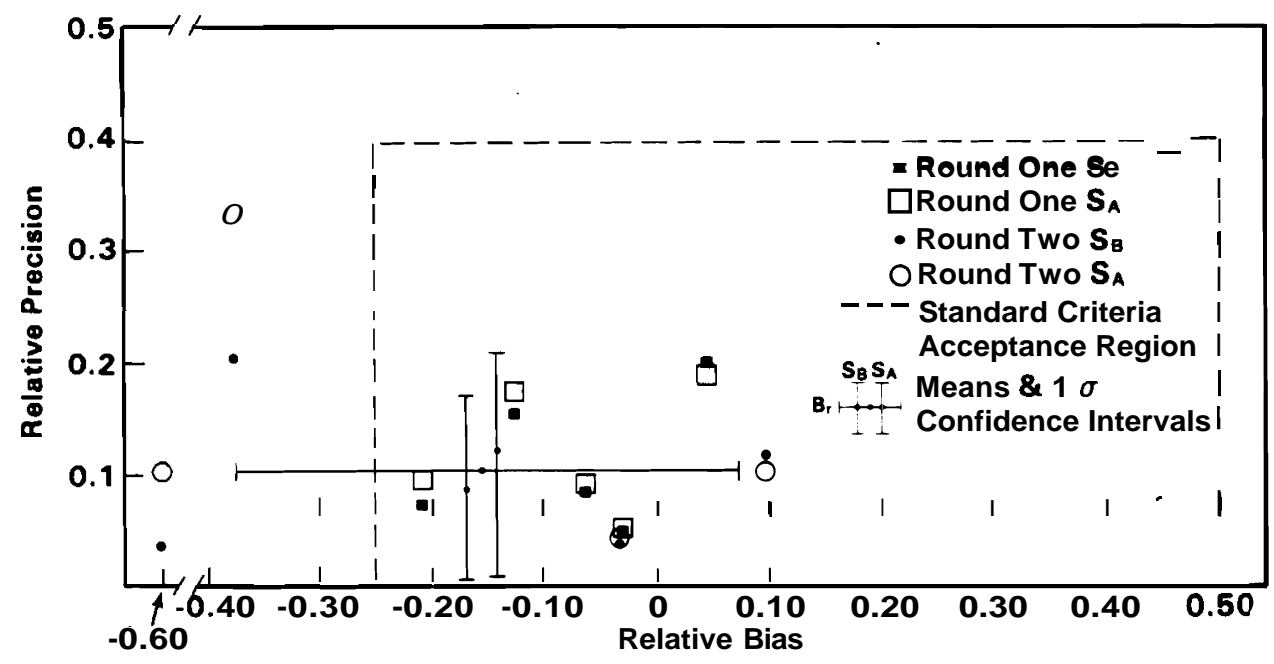

FIGURE 6. $\quad{ }^{241}$ Am Relative Precision and Relative Bias

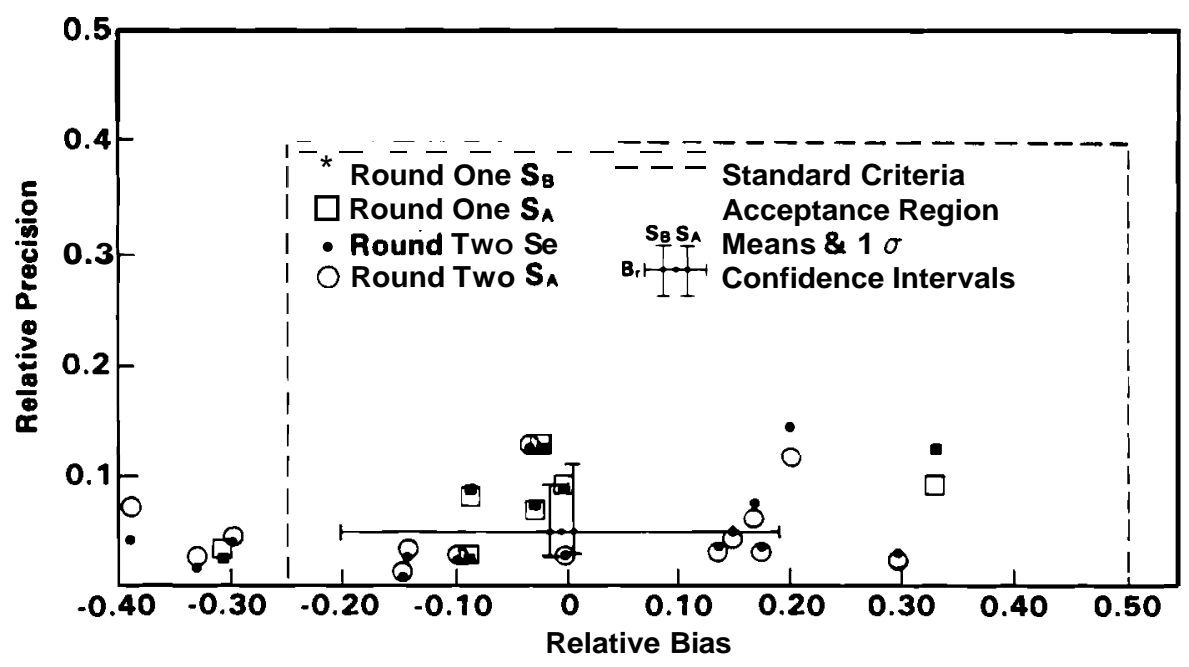

FIGURE 7. nat $_{U}$ Relative Precision and Relative Bias 


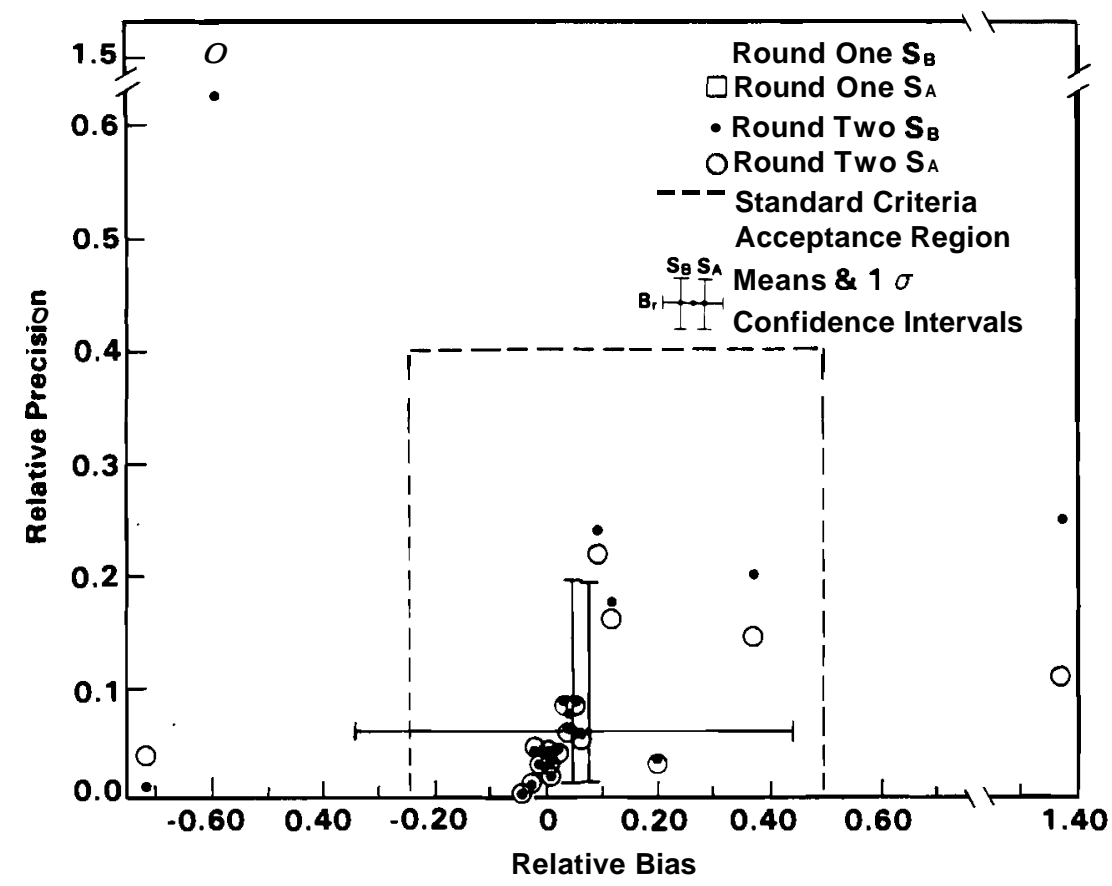

FIGURE 8. ${ }^{60}$ Co Relative Precision and Relative Bias

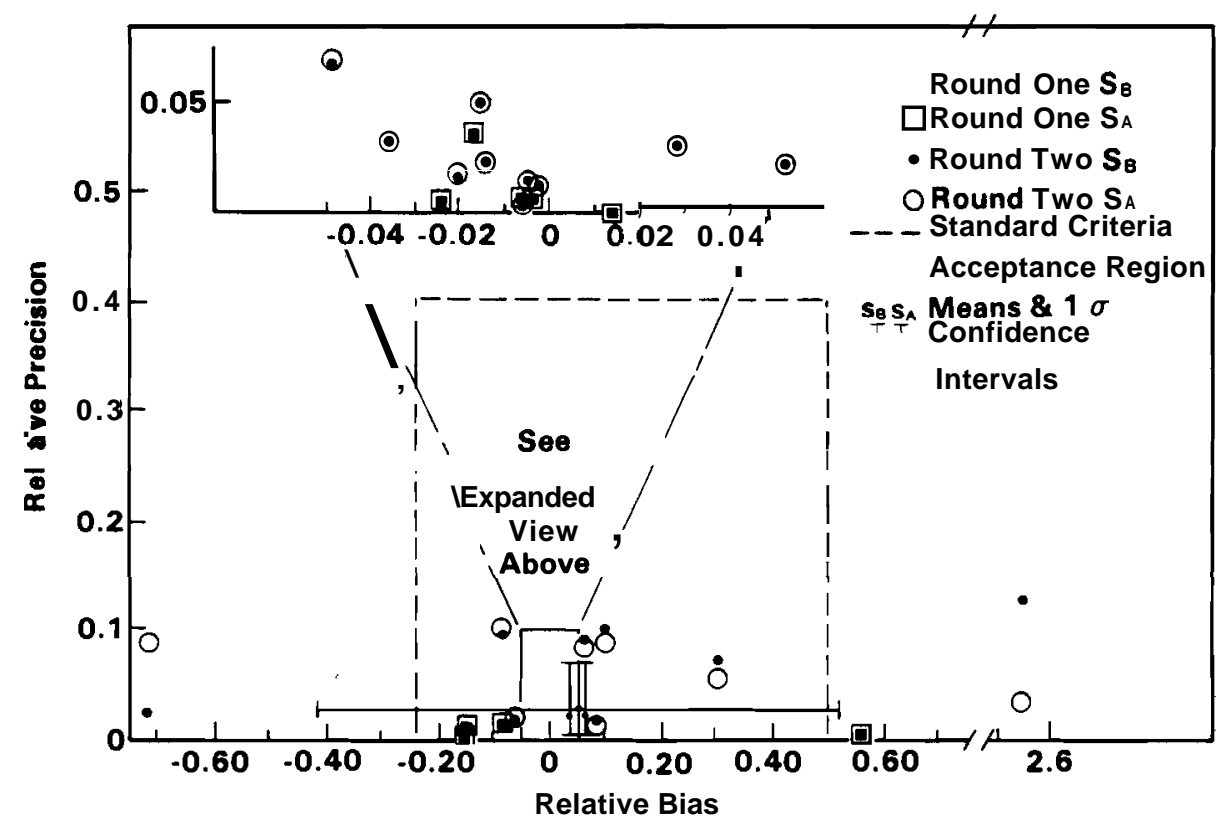

FIGURE 9. ${ }^{137}$ Cs Relative Precision and Relative Bias 
For Figure 10, each calculated MDA was normalized by dividing by the appropriate AMDA. This technique simplified comparisons among the categories where AMDAs vary by up to a factor of $10^{6}$. Plotted values greater than 1.0 represented a failure of the MDA criterion. A number of respondents did not supply adequate data to calculate an MDA Missing data included gross counts on the unspiked samples, counting times, efficiency factors, and volume of the analyzed sub-sample.

Tritium MDAs were all less than the AMDA (100 $\mathrm{nCi} / \mathrm{L})$, and all but two were less than $10 \mathrm{nCi} / \mathrm{L}$. For ${ }^{90} \mathrm{Sr}$, a11 except one laboratory $\mathrm{MDA}$ were below the AVDA $(10 \mathrm{pCi} / \mathrm{L})$. The geometric means of MDAs for natural uranium and ${ }^{137}$ Cs were less than their AMDAs. Only 4 of the 18 laboratories $(22 \%)$ that reported adequate data to calculate an MDA for natural uranium failed this criterion. Likewise; 4 of 12 laboratories (33\%) failed the AMDA for ${ }^{137} \mathrm{Cs}$.

The geometric means of MDAs for ${ }^{89} \mathrm{Sr},{ }^{238} \mathrm{Pu},{ }^{241} \mathrm{Am}$, and ${ }^{60} \mathrm{Co}$ were a II greater than their AMDAs but less than twice their AMDA. AMDA failure fractions for ${ }^{89} \mathrm{Sr},{ }^{238} \mathrm{Pu}$, and ${ }^{241} \mathrm{Am}$ were all greater than $50 \%$. The numbers were three of five $(60 \%)$ and four of six $(67 \%)$, respectively. Only three of seven (43\%) failed the ${ }^{60}$ Co AMDA

Calculated MDAs for laboratories participating in both rounds of a nuclide category were compared to determine whether any trends (i.e., improvements in measurement capability) could be identified. Unfortunately, only 12 of 38 laboratory MDA calculations could be repeated as shown in Table 7, and no discernible trends were identified. A paired t-test resulted in a value of -0.58 for the $t$-statistic with 11 degrees of freedom, which was not significant at the level $P=0.1$. The conclusion was, therefore, that participation in both rounds did not result in a significant change in calculated MDA (see the data presented in Table 8).

Figures 11 through 18 show, by nuclide category and testing round, piechart results of in vitro testing results. As explained for Table 6, inadequate data meant that the participant did not supply complete data for one or more of the criteria (usually MDA) but did pass all other criteria. If inadequate data had been supplied to calculate MDA and the laboratory also failed $B_{r}$, the result counted as a failure of $B_{r}$. 


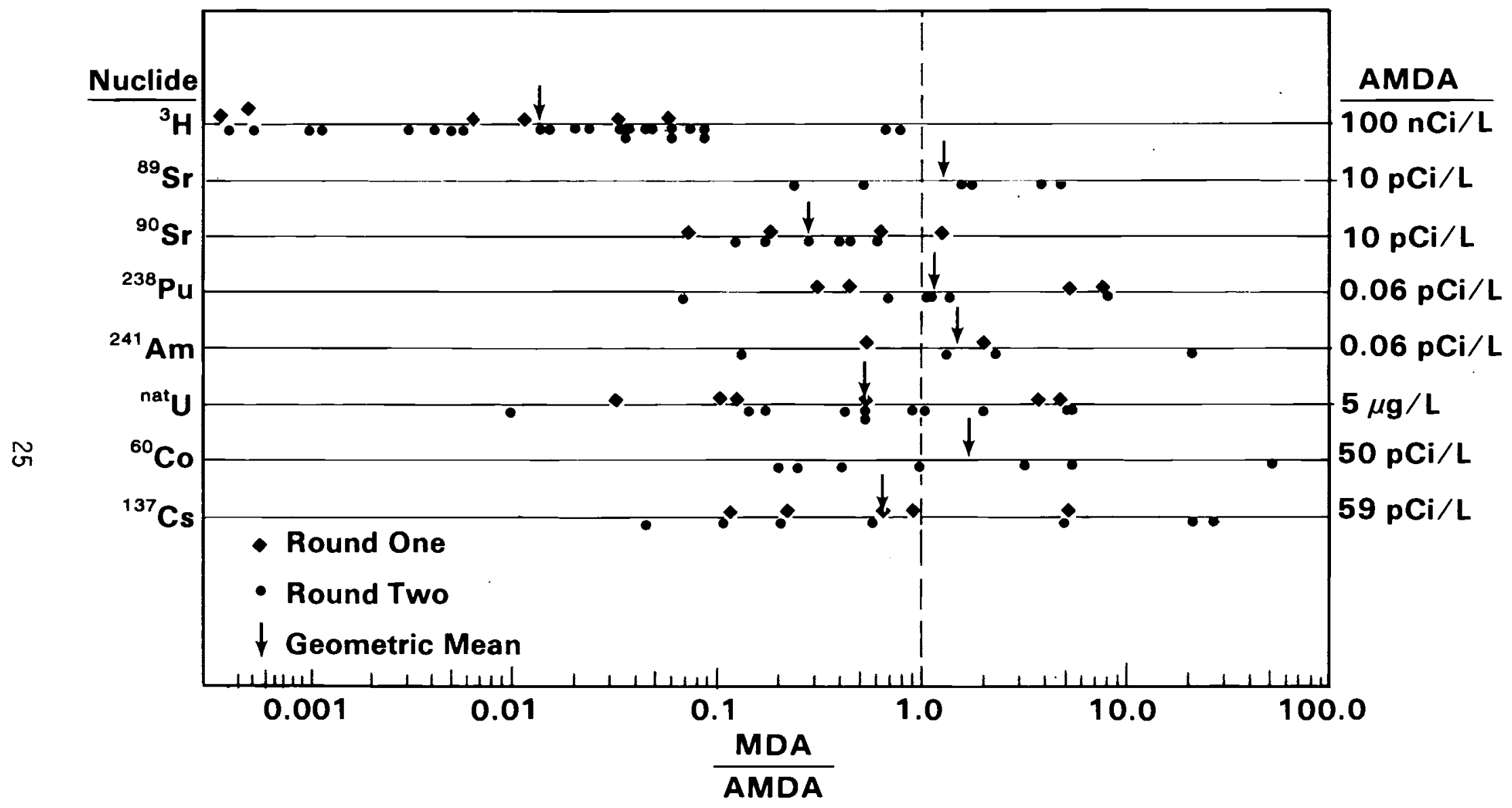

FIGURE 10 Normalized MDA Results 
TABLE 7. MDAs for Laboratories Participating in Both Rounds

\begin{tabular}{|c|c|c|c|}
\hline Nucli ide & Laboratory Code & Round One & Round Two \\
\hline \multirow[t]{5}{*}{$3_{H}$} & $\mathrm{~J}$ & 5.81 & 7.51 \\
\hline & L & .03 & .31 \\
\hline & M & 3.46 & .72 \\
\hline & $S$ & .64 & 4.61 \\
\hline & V & 1.12 & 4.59 \\
\hline${ }^{90} \mathrm{Sr}$ & $E$ & 1.86 & 6.15 \\
\hline \multirow[t]{3}{*}{ nat $_{U}$} & H & 2.68 & 2.63 \\
\hline & $K$ & .17 & 4.56 \\
\hline & $S$ & .63 & .05 \\
\hline \multirow[t]{3}{*}{${ }^{137} \mathrm{Cs}$} & G & 12.8 & 6.52 \\
\hline & $L$ & 38.8 & 2.72 \\
\hline & $M$ & 6.78 & 88.5 \\
\hline
\end{tabular}

TABLE 8. Changes in Results for Laboratory Participation in Both Rounds

\begin{tabular}{|c|c|c|c|c|c|}
\hline $\begin{array}{l}\text { Nuclide } \\
\text { Category } \\
\end{array}$ & $\begin{array}{c}\text { Repeat } \\
\text { Laboratories } \\
\end{array}$ & $\begin{array}{c}\text { Maintained } \\
\text { Pass } \\
\end{array}$ & $\begin{array}{r}\text { Improved } \\
\text { to Pass } \\
\end{array}$ & $\begin{array}{c}\text { Declined to } \\
\text { Failure or } \\
\text { Inadequate } \\
\text { Data } \\
\end{array}$ & $\begin{array}{l}\text { Maintained } \\
\text { Failure or } \\
\text { Inadequate } \\
\text { Data } \\
\end{array}$ \\
\hline $3_{H}$ & 6 & 5 & 1 & 0 & 0 \\
\hline${ }^{90} \mathrm{Sr}$ & 1 & 0 & 0 & 1 & 0 \\
\hline${ }^{238} \mathrm{Pu}$ & 1 & 1 & 0 & 0 & 0 \\
\hline${ }^{241} \mathrm{Am}$ & 1 & 0 & 0 & 0 & 1 \\
\hline nat $_{U}$ & 5 & 3 & 0 & 1 & 1 \\
\hline${ }^{137} \mathrm{Cs}$ & 7 & 2 & 1 & 2 & 2 \\
\hline Total & 21 & 11 & 2 & 4 & 4 \\
\hline
\end{tabular}




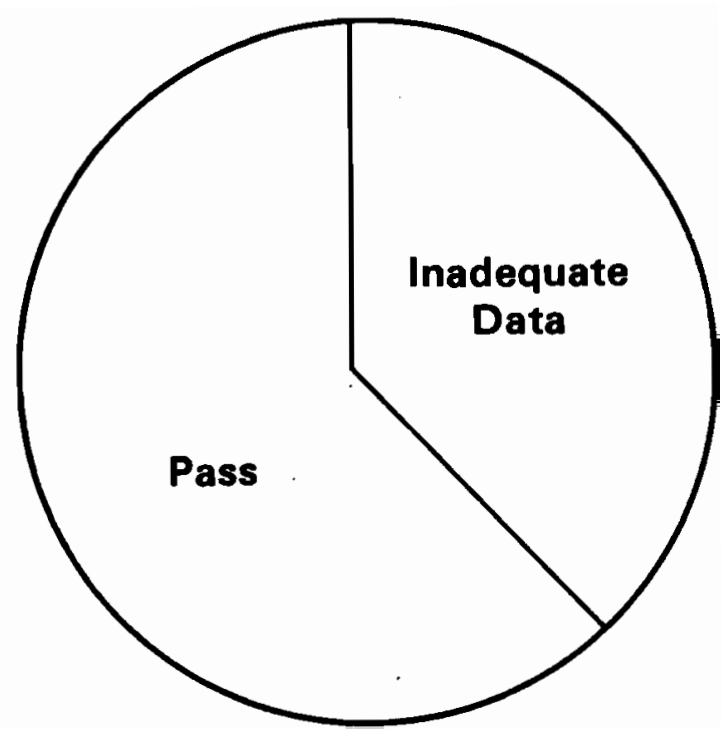

Round One, $n=8$

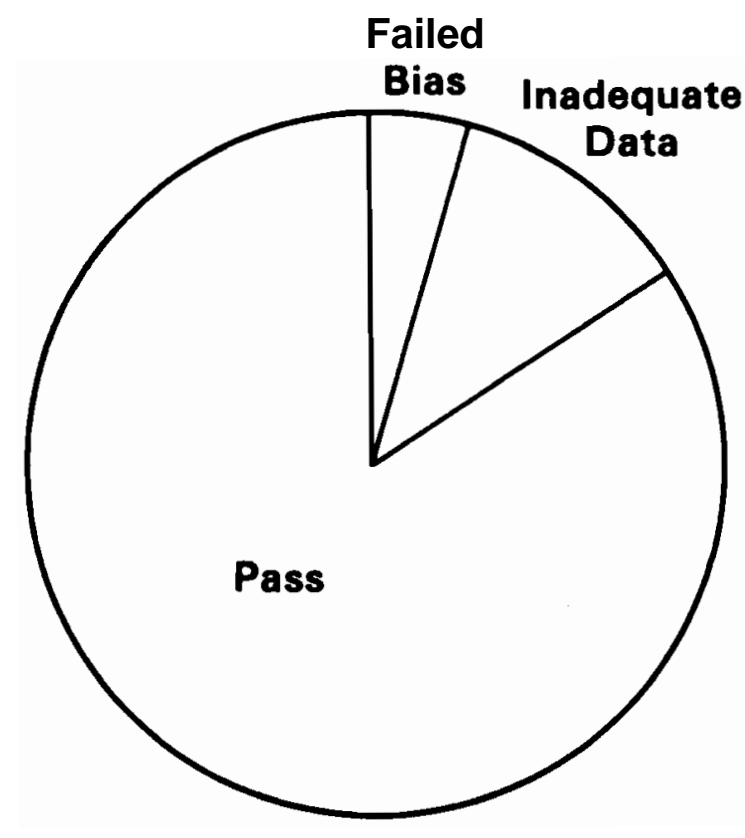

Round Two, $n=28$

FIGURE $11 . \quad{ }^{3}$ Hesults

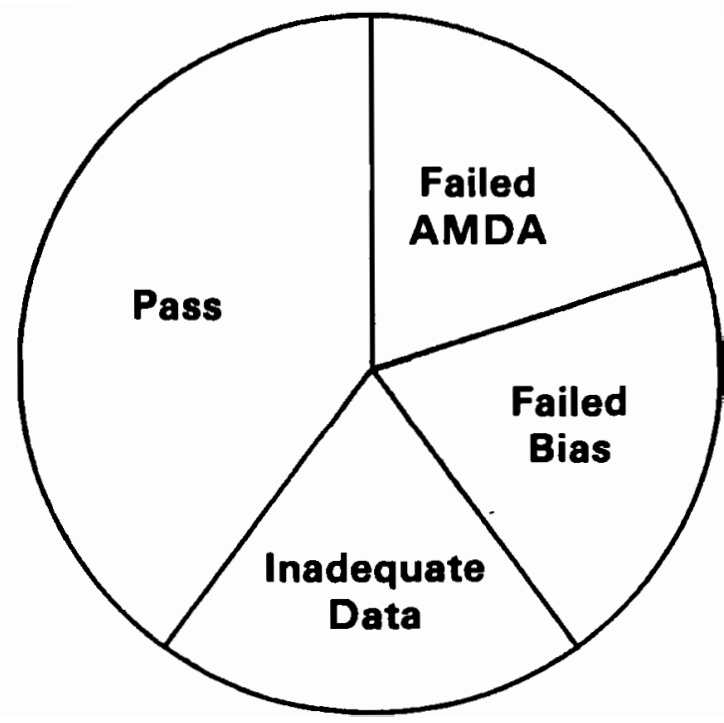

Round One, $n=5$

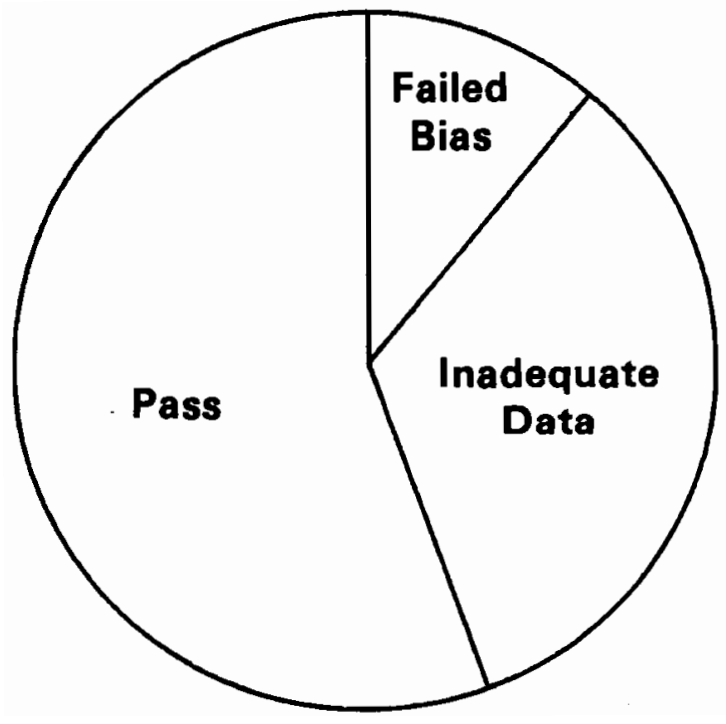

Round Two, $n=9$

FIGURE 12. ${ }^{90}$ Sr Results 


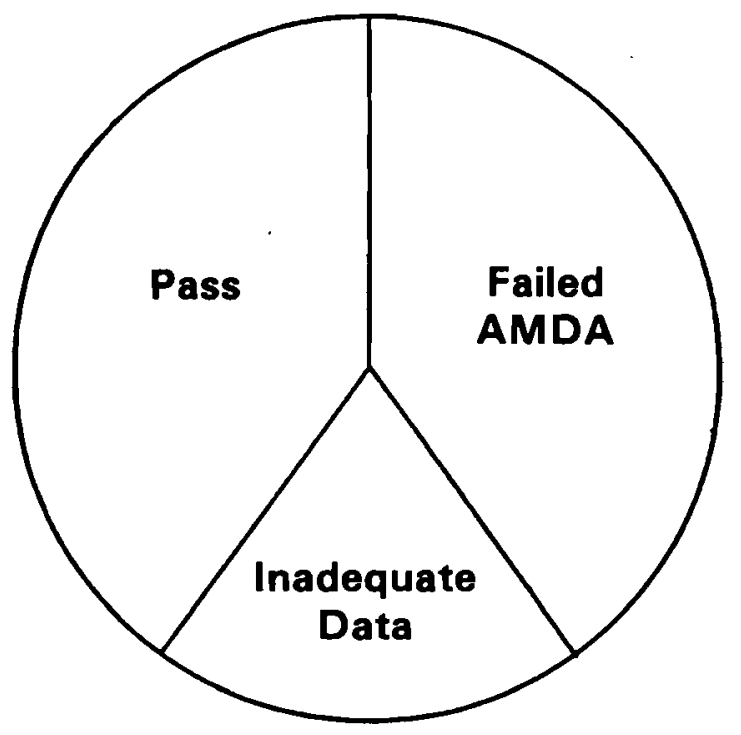

Round One, $n=5$

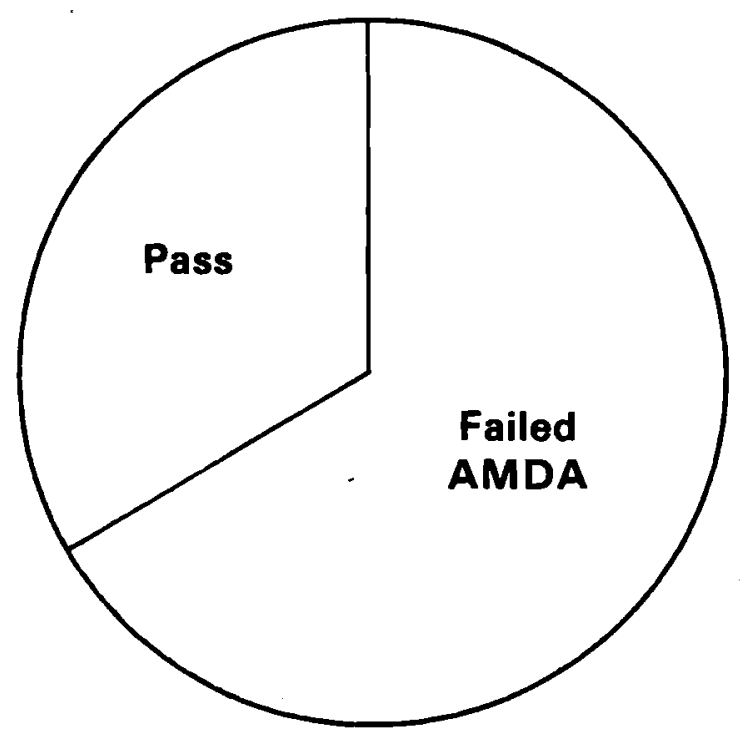

Round Two, $n=6$

FIGURE $13 . \quad{ }^{238} \mathrm{Pu}$ Results

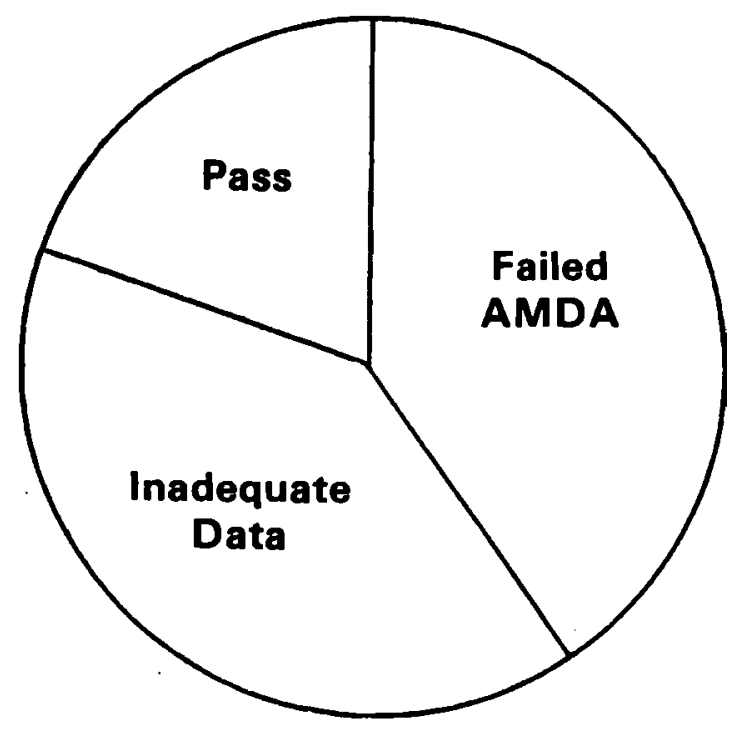

Round One, $n=5$

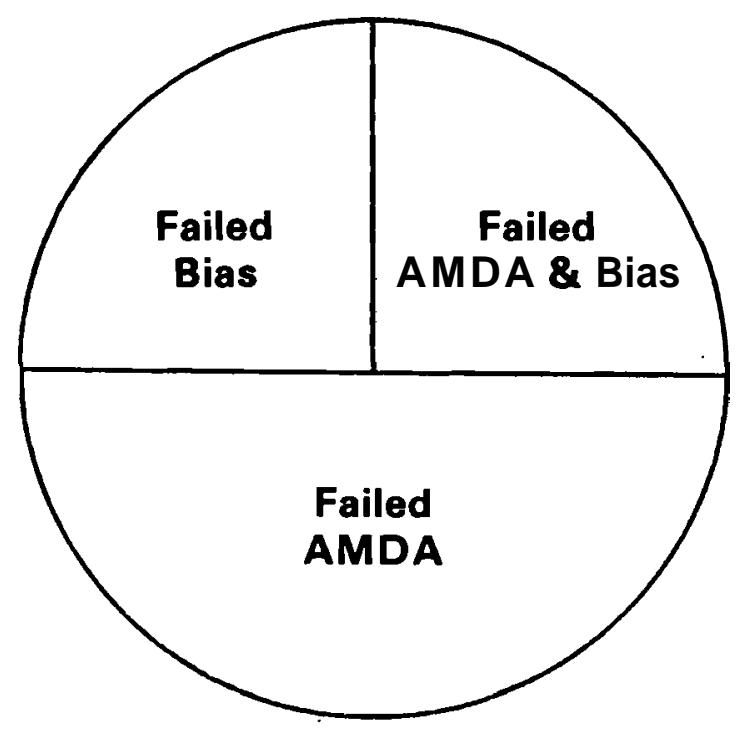

Round Two, $n=4$

FIGURE $14 . \quad{ }^{241}$ Am Results 


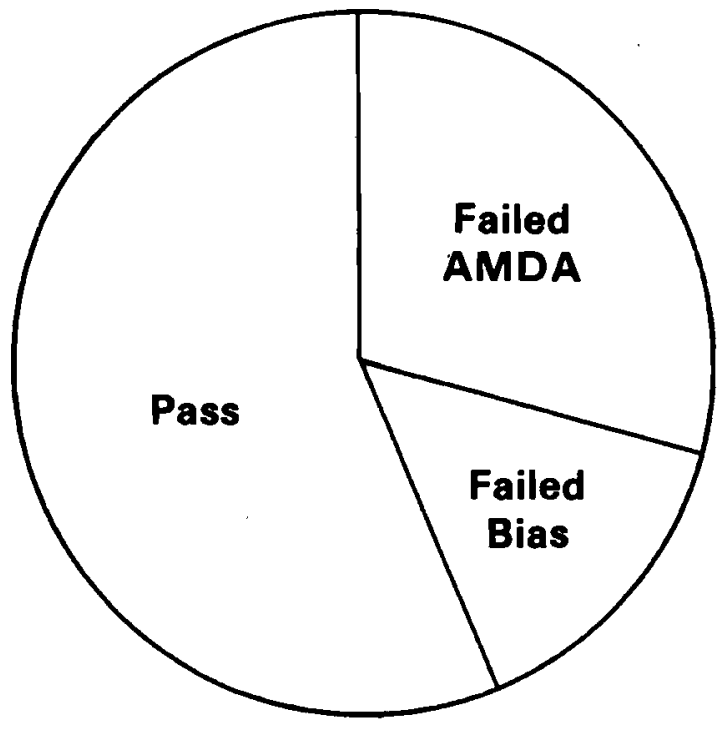

Round One, $n=7$

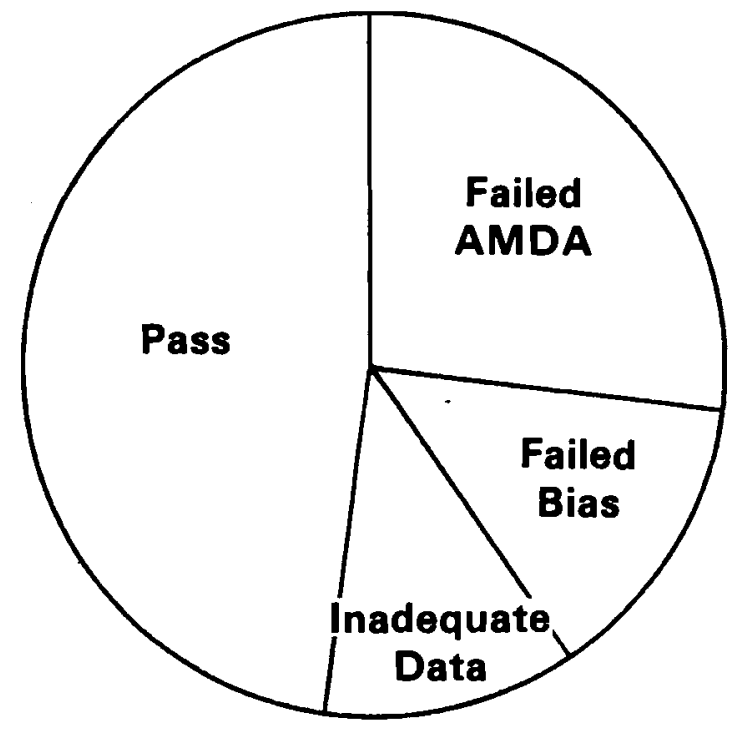

Round Two, n=15

FIGURE 15. Natural Uranium ( ${ }^{\text {nat }_{U}}$ ) Results

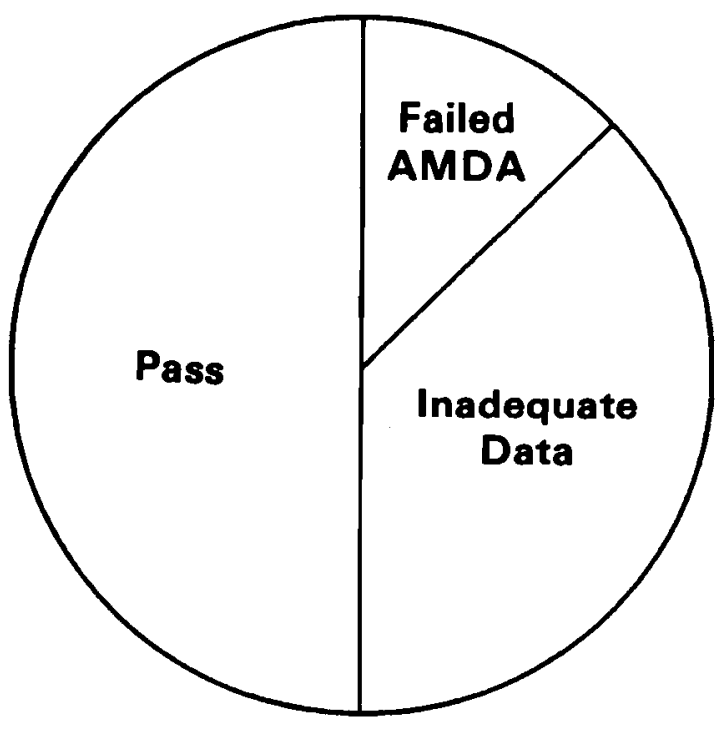

Round One, $\mathrm{n}=8$

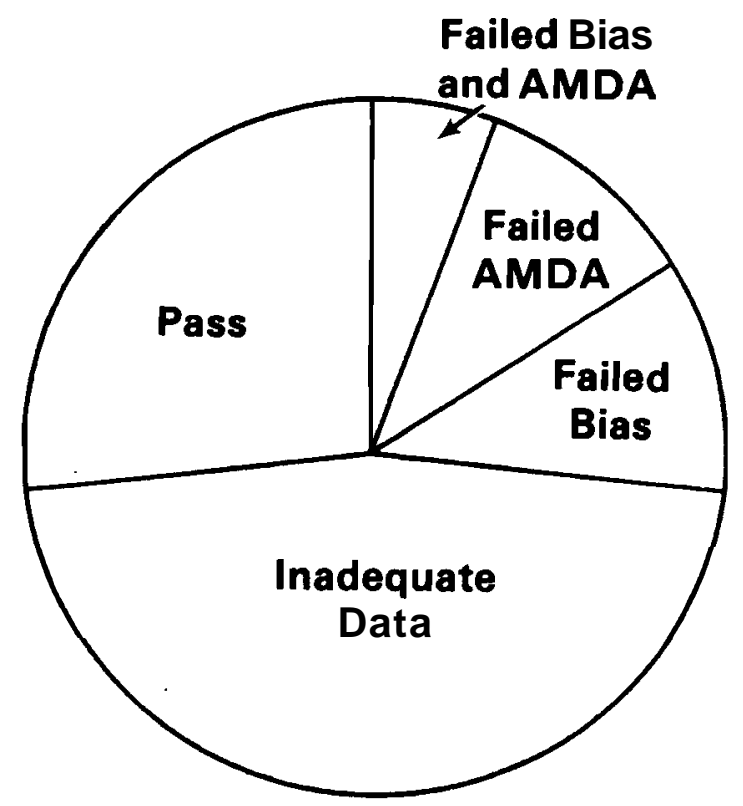

Round Two, $n=19$

FIGURE $16 . \quad{ }^{137}$ Cs Result s 


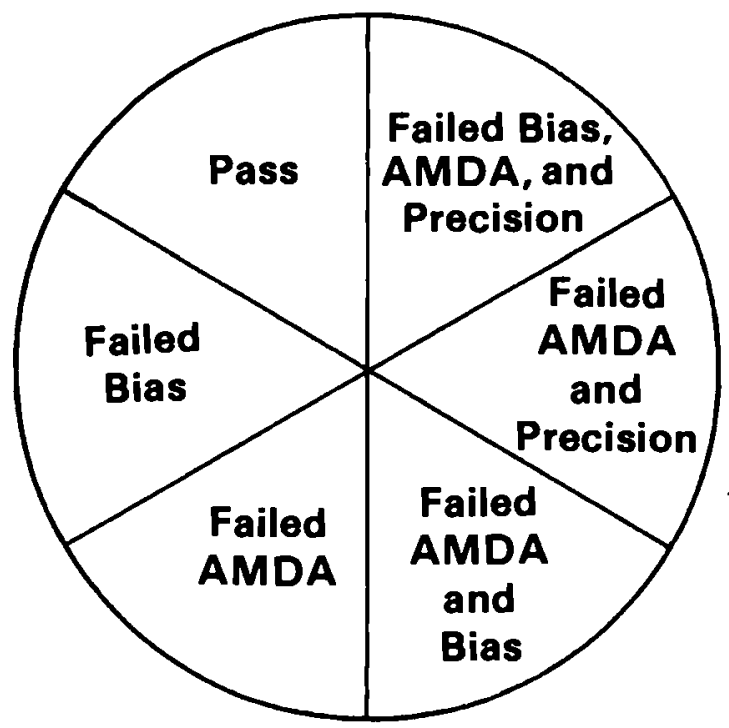

${ }^{89}$ Sr Round Two, $n=6$

FIGURE $17 .{ }^{89}$ Sr Results

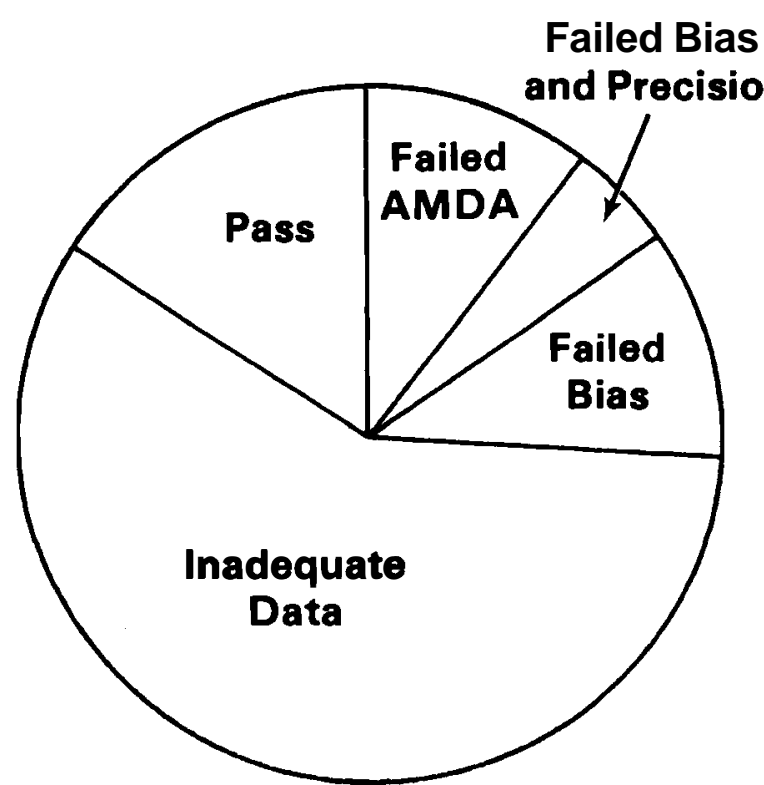

60Co Round Two, $n=19$

FIGURE $18 .{ }^{60}$ Co Results 
For both ${ }^{3} \mathrm{H}$ and ${ }^{90} \mathrm{Sr}$ (see Figures 11 and 12 ), the failing fraction decreased and the passing fraction increased from Round One to Round Two, and more than $50 \%$ of the laboratories passed in Round Two. In neither case did a participant fail the AVDA criterion in Round Two.

For ${ }^{238} \mathrm{Pu}$ (see Figure 13 ), although only one laboratory participated in both rounds, the pass fraction remained relatively constant $(\sim 35 \%)$. The fraction failing the AMDA criterion in Round Two nearly equaled the total fraction in Round One either failing AMDA or providing inadequate data to calculate an MDA $(\sim 65 \%)$.

As seen in Figure 14, the pass rate for ${ }^{241}$ Am went from 1 of $5(20 \%)$ in Round One to zero (0\%) in Round Two. Again, only 1 laboratory participated in both rounds. This participant provided inadequate data for calculating an MDA for Round One, and it failed $B_{r}$ for Round Two. Overall, only 1 of 10 1aboratories passed this performance criterion.

Results for natural uranium are summarized in Figure 15. Six of the seven participants from Round One also participated in Round Two. Nine additional participants were added for Round Two. All but one of the repeat laboratories obtained the same outcome for both rounds, and the failure rate for all participants remained fairly constant ( 40\%).

Seven of the eight ${ }^{137}$ Cs Round One participants also participated in Round Two (see Figure 16). Only three of the seven remained in the same category (i.e., pass, fail, or inadequate data). The trend for the repeat laboratories was toward passing, but the overall failure rate increased $(13 \%$ to $26 \%$ ), and the pass rate decreased (50\% to $26 \%$ ).

Testing for ${ }^{89} \mathrm{Sr}$ (see Figure 17) and ${ }^{60} \mathrm{Co}$ (see Figure 18) was done only in Round Two. Only 1 of 6 (17\%) participants passed ${ }^{89} \mathrm{Sr}$ and the other 5 failed various combinations of the three performance criteria. For ${ }^{60}$ Co, 3 of $19(16 \%)$ passed and 5 of 19 (26\%) failed.

Overall, it appeared that prior participation in testing had little affect on a laboratory's ability to pass all the standard criteria. 
Laboratory performance declined in more categories than those in which it improved (4 versus 2). Seventy percent of' the labs maintained their previous performance levels.

NATURAL VERSUS ARTIFICIAL URINE COMPARISON

To test the suitability of the artificial urine matrix, equal volumes of artificial and natural urine were spiked with equal amounts of radionuclides. Artificial urine was prepared as described in Appendix B, and natural urine was collected from volunteers not occupationally exposed to the test nuclides.

For each nuclide and matrix category, four replicate samples with concentrations approximately five times the AMDA and four blank samples were prepared. The nuclides chosen were ${ }^{90} \mathrm{Sr},{ }^{238} \mathrm{Pu}$, and natural uranium. These nuclides were thought most likely to show effects from the matrix. The samples were sent to an independent laboratory of known capabilities for analysis.

Tables 9, 10, and 11 show results of the analyses for ${ }^{238} \mathrm{Pu},{ }^{90} \mathrm{Sr}$, and natural uranium, respectively. For each matrix, the mean blank result was subtracted from the reported value for the sample and the result normalized to the known amount. Normalization allowed direct comparison of the matrices, which had slightly different spike amounts. Standard deviations calculated from the reported values were propagated to estimate the error of the mean normalized values.

The normalized mean results were analyzed using analysis of variance (ANOVA) (see Table 12). From this procedure, the hypothesis could not be rejected that the artificial and natural urines were reacting in the same manner during the analysis. However, significant differences among the nuclides were found. For example, Table 9 shows that the mean reported value for the ${ }^{238} \mathrm{Pu}$ analysis was approximately $90 \%$ of the known value, while ${ }^{90} \mathrm{Sr}$ (see Table 10) and natural uranium (Table 11) were in the $60-70 \%$ range. Although determination of bias was important to the objective of the main project, the appropriateness of the artificial urine was evaluated using only the ratio of the artificial urine to natural urine results. Based on this 
TABLE 9. Artificial Versus Natural Urine Comparison with ${ }^{238} \mathrm{Pu}$

\begin{tabular}{|c|c|c|c|c|c|c|}
\hline \multirow[b]{2}{*}{ Sample No. } & \multirow[b]{2}{*}{ Matrix } & \multicolumn{4}{|c|}{ Activity, $\mathrm{pCi} / \mathrm{L}$} & \multirow[t]{2}{*}{$\begin{array}{l}\text { Ratio- } \\
\text { Mean Net } \\
\text { Activity } \\
\text { and Added } \\
\text { Activity }\end{array}$} \\
\hline & & Added & & Reported & Net & \\
\hline 1Pu & Artificial & 0 & & 0.0000 & & \\
\hline $2 \mathrm{Pu}$ & Artificial & 0 & & 0.0014 & & \\
\hline $3 \mathrm{Pu}$ & Artificial & 0 & & -0.0002 & & \\
\hline \multirow[t]{3}{*}{$4 \mathrm{Pu}$} & Artificial & 0 & & $\underline{0.0007}$ & & \\
\hline & & & Mean & 0.0005 & & \\
\hline & & & S.D. & 0.0007 & & \\
\hline $5 \mathrm{Pu}$ & Artificial & 0.352 & & 0.2899 & 0.2892 & 0.8216 \\
\hline $6 \mathrm{Pu}$ & Artificial & 0.352 & & 0.3189 & 0.3182 & 0.9041 \\
\hline $7 \mathrm{Pu}$ & Artificial & 0.352 & & 0.2890 & 0.2883 & 0.8190 \\
\hline \multirow[t]{3}{*}{$8 \mathrm{Pu}$} & Artificial & 0.352 & & 0.3362 & 0.3355 & $\underline{0.9531}$ \\
\hline & & & Mean & 0.3085 & 0.3078 & 0.8745 \\
\hline & & & S.D. & 0.0231 & 0.0231 & 0.0702 \\
\hline $9 \mathrm{Pu}$ & Natural & 0 & & 0.0010 & & \\
\hline $10 \mathrm{Pu}$ & Natural & 0 & & 0.0013 & & \\
\hline $11 \mathrm{Pu}$ & Natural & 0 & & 0.0003 & & \\
\hline \multirow[t]{3}{*}{$12 \mathrm{Pu}$} & Natural & 0 & & 0.0000 & & \\
\hline & & & Mean & 0.0007 & & \\
\hline & & & S.D. & 0.0006 & & \\
\hline $13 \mathrm{Pu}$ & Natural & 0.335 & & 0.2898 & 0.2891 & 0.8630 \\
\hline $14 \mathrm{Pu}$ & Natural & 0.335 & & 0.2933 & 0.2826 & 0.8734 \\
\hline $15 \mathrm{Pu}$ & Natural & 0.335 & & 0.3656 & 0.3649 & 1.0893 \\
\hline \multirow[t]{3}{*}{$16 \mathrm{Pu}$} & Natural & 0.335 & & $\underline{0.2997}$ & 0.2990 & $\underline{0.8925}$ \\
\hline & & & Mean & 0.3121 & 0.3089 & 0.9296 \\
\hline & & & S.D. & 0.0359 & 0.0359 & 0.1116 \\
\hline
\end{tabular}


TABLE 10. Artificial Versus Natural Urine Comparison with ${ }^{90} \mathrm{Sr}$

\begin{tabular}{|c|c|c|c|c|c|c|}
\hline Sample No. & Matrix & \multicolumn{4}{|c|}{ Activity, $\mathrm{pC} / \mathrm{L}$} & $\begin{array}{l}\text { Ratio- } \\
\text { Mean Net } \\
\text { Activity } \\
\text { and Added } \\
\text { Activity } \\
\end{array}$ \\
\hline & & & & & & \\
\hline $15 r$ & Artificial & 0 & & 1.3002 & & \\
\hline $2 S r$ & Artificial & & & 0 & 0.6098 & \\
\hline $35 r$ & Artificial & & & 0 & 1.5670 & \\
\hline \multirow[t]{3}{*}{$4 S r$} & Artificial & & & $\underline{0}$ & 0.8134 & \\
\hline & & & Mean & 1.0726 & & \\
\hline & & & S.D. & 0.4388 & & \\
\hline $5 \mathrm{Sr}$ & Artificial & 59.4 & & 43.8608 & 42.7882 & 0.7203 \\
\hline $6 \mathrm{Sr}$ & Artificial & 59.4 & & 40.3267 & 39.2541 & 0.6608 \\
\hline $7 \mathrm{Sr}$ & Artificial & 59.4 & & 32.7450 & 31.6724 & 0.5332 \\
\hline \multirow[t]{3}{*}{$8 \mathrm{Sr}$} & Artificial & 59.4 & & 34.2705 & 33.1979 & 0.5589 \\
\hline & & & Mean & 37.8008 & 36.7282 & 0.6183 \\
\hline & & & S.D. & 5.2003 & 5.2188 & 0.1117 \\
\hline $9 S r$ & Natural & 0 & & 0.4945 & & \\
\hline $10 S r$ & Natural & 0 & & 0.3478 & & \\
\hline $11 S r$ & Natural & 0 & & 0.4872 & & \\
\hline \multirow[t]{3}{*}{$12 S r$} & Natural & 0 & & 0.3368 & & \\
\hline & & & Mean & 0.4166 & & \\
\hline & & & S.D. & 0.0859 & & \\
\hline $13 S r$ & Natural & 56.5 & & 45.1324 & 44.7158 & 0.7914 \\
\hline $14 S r$ & Natural & 56.5 & & 38.3883 & 37.9717 & 0.6721 \\
\hline $15 S r$ & Natural & 56.5 & & 55.8034 & 55.3868 & 0.9803 \\
\hline \multirow[t]{3}{*}{$16 \mathrm{Sr}$} & Natural & 56.5 & & 38.1545 & 37.7379 & 0.6679 \\
\hline & & & Mean & 44.3697 & 43.9531 & 0.7779 \\
\hline & & & S.D. & 8.2808 & 8.2812 & 0.1662 \\
\hline
\end{tabular}


TABLE 11. Artificial Versus Natural Urine Comparison with Natural Uranium

\begin{tabular}{|c|c|c|c|c|c|c|}
\hline \multirow[b]{2}{*}{ Sample No. } & \multirow[b]{2}{*}{ Matrix } & \multicolumn{4}{|c|}{ Activity, $\mathrm{pC} \mathrm{C} / \mathrm{L}$} & \multirow[t]{2}{*}{$\begin{array}{l}\text { Ratio- } \\
\text { Mean Net } \\
\text { Activity } \\
\text { and Added } \\
\text { Activity } \\
\end{array}$} \\
\hline & & Added & & Reported & Net & \\
\hline $17 U$ & Artificial & 0 & & 0.0596 & & \\
\hline $18 U$ & Artificial & 0 & & 0.0386 & & \\
\hline $19 U$ & Artificial & 0 & & 0.0379 & & \\
\hline \multirow[t]{3}{*}{$20 U$} & Artificial & 0 & & $\underline{0.0812}$ & & \\
\hline & & & Mean & 0.0543 & & \\
\hline & & & S.D. & 0.0206 & & \\
\hline 210 & Artificial & 24.2 & & 17.8999 & 17.8456 & 0.7374 \\
\hline $22 \mathrm{U}$ & Artificial & 24.2 & & 19.2676 & 19.2133 & 0.7939 \\
\hline $23 U$ & Artificial & 24.2 & & 15.7030 & 15.6487 & 0.6466 \\
\hline \multirow[t]{3}{*}{$24 U$} & Artificial & 24.2 & & 16.7282 & 16.6789 & 0.6890 \\
\hline & & & Mean & 17.3997 & 17.3454 & 0.7168 \\
\hline & & & S.D. & 1.5350 & 1.5351 & 0.0749 \\
\hline $25 \mathrm{U}$ & Natural & 0 & & 0.1237 & & \\
\hline $26 \mathrm{U}$ & Natural & 0 & & 0.1118 & & \\
\hline $27 U$ & Natural & 0 & & 0.0681 & & \\
\hline \multirow[t]{3}{*}{$28 \mathrm{U}$} & Natural & 0 & & $\underline{0.2049}$ & & \\
\hline & & & Mean & 0.1271 & & \\
\hline & & & S.D. & 0.0571 & & \\
\hline $29 U$ & Natural & 26.7 & & 19.4747 & 19.2476 & 0.7246 \\
\hline $30 U$ & Natural & 26.7 & & 18.6455 & 18.5184 & 0.6936 \\
\hline $31 U$ & Natural & 26.7 & & 16.2126 & 16.0855 & 0.6025 \\
\hline \multirow[t]{3}{*}{$32 U$} & Natural & 26.7 & & $\underline{19.3315}$ & 19.2044 & 0.7193 \\
\hline & & & Mean & 18.4161 & 18.2890 & 0.6850 \\
\hline & & & S.D. & 1.5129 & 1.5140 & 0.0685 \\
\hline
\end{tabular}


TABLE 12. Analysis of Variance of Urine Matrix Comparison

\begin{tabular}{lcccccc}
\multicolumn{1}{c}{ Source } & Sum of Squares & $\begin{array}{c}\text { Degrees of } \\
\text { Freedom }\end{array}$ & $\begin{array}{c}\text { Mean } \\
\text { Squares }\end{array}$ & $\mathrm{F}$ (fixed) & Probability $(\mathrm{P})$ \\
\cline { 1 - 4 } Matrices & & 0.0223 & 1 & 0.0223 & 2.5683 & $10 \%<P<25 \%$ \\
Nuclides & & 0.2187 & 2 & 0.1094 & 12.5773 & $0.1 \%<P<0.5 \%$ \\
Interactions & 0.0367 & 2 & 0.0184 & 2.1114 & $10 \%<P<25 \%$ \\
Within Cells & 0.1567 & 18 & 0.0087 & & \\
\hline Totals & 0.4343 & 24 & 0.0189 & &
\end{tabular}

test, the artificial urine was accepted as a suitable test matrix for this project and for future testing in compliance with draft ANSI Standard N13.30.

The difference between the artificial and natural urines for each nuclide was also determined using the Student $t$-test, assuming unequal and unknown variances (see Table 13) and using an approximation for the degrees of

TABLE 13. Urine Matrices Comparison Testing

\begin{tabular}{|c|c|c|c|}
\hline Artificial Urine & ${ }^{238} \mathrm{Pu}$ & ${ }^{90} \mathrm{Sr}$ & nat $_{U}$ \\
\hline $\begin{array}{l}\text { Mean Ratio Net and } \\
\text { Added Activity }\end{array}$ & 0.8745 & 0.6183 & 0.7167 \\
\hline $\begin{array}{l}\text { Variance of Mean } \\
\text { Ratio }\end{array}$ & 0.0043 & 0.0076 & 0.0040 \\
\hline Deg. of Freedom & 3 & 3 & 3 \\
\hline \multicolumn{4}{|l|}{ Natural Urine } \\
\hline $\begin{array}{l}\text { Mean Ratio Net and } \\
\text { Added Activity }\end{array}$ & 0.9295 & 0.7779 & 0.6850 \\
\hline $\begin{array}{l}\text { Variance of Mean } \\
\text { Ratio }\end{array}$ & 0.0115 & 0.0215 & 0.0032 \\
\hline Deg. of Freedom & 3 & 3 & 3 \\
\hline t Value & 0.8771 & 1.8702 & 0.7461 \\
\hline Approx. D. F. & 5 & 5 & 6 \\
\hline Significance Level & $\sim 40 \%$ & $\sim 10 \%$ & $\sim 40 \%$ \\
\hline
\end{tabular}


freedom (Nie et al. 1975). The hypothesis that the normalized results are identical for the natural and artificial urine matrices was accepted for ${ }^{238} \mathrm{Pu}$ and for natural uranium and was weakly rejected at the $10 \%$ level for ${ }^{90} \mathrm{Sr}$. Although results for ${ }^{90} \mathrm{Sr}$ were inconclusive, further investigation was warranted.

Two Round Two participants reported difficulty with the ${ }^{89} \mathrm{Sr} /{ }^{90} \mathrm{Sr}$ analyses. These participants observed that strontium extraction from the artificial urine resulted in incomplete purification. Impure samples gave recovery estimates that were biased high, which in turn resulted in a negative measurement bias. The possibility was considered that impurities occur because of the relatively low $\mathrm{pH}$ of the samples. Concentrated nitric acid was added to the artificial urine matrix to ensure that spike radionuclides would remain in ionic form. Following a re-evaluation of the artificial urine recipe, the conclusion drawn was that the acid can be reduced from $50 \mathrm{~g} / \mathrm{kg}$ to $10 \mathrm{~g} / \mathrm{kg}$ without risking precipitation of the spike. Future test samples will be prepared with only $10 \mathrm{~g} / \mathrm{kg} \mathrm{nitric} \mathrm{acid} \mathrm{matrix,} \mathrm{and} \mathrm{this}$ change should correct the potential strontium purification problem. Also, early tests of the artificial urine suggested that food color might cause a precipitate. Yellow food coloring was originally added to indicate that the sample represented urine. If sample color is a significant factor in the procedure tested, such as liquid scintillation counting without distillation, an appropriate organic colorant should instead be used.

\section{THIRD-PARTY CROSSCHECK ANALYSIS}

The results of the third-party laboratory analyses ${ }^{(a)}$ are shown in Table 14 and are compared to the desired radionuclide concentrations. In general, the agreement was excellent between measured uranium levels and intended levels and indicated that the dilution scheme was followed as planned. In addition, selected urine samples containing uranium were measured at PNL using laser phosphorimetry (Bushaw 1982). Again, the agreement between measured uranium levels and intended levels was excellent.

(a) Third-party analyses were performed by TMA/Norcal, Richmond, California. 


\section{TABLE 14. Third-Party Crosscheck of Spiked Artificial Urine Samples}

Round One

\begin{tabular}{|c|c|c|c|c|c|}
\hline Nuclide & $\begin{array}{l}\text { Third-Party } \\
\text { Assay Results } \pm 1 \sigma^{(a)} \\
\end{array}$ & $\begin{array}{l}\text { PNL-Calcul a ted } \\
\text { Results } \bullet 1 \sigma^{(b)}\end{array}$ & $\begin{array}{l}\text { Third-Party } \\
\text { Assay Results } \pm 1 \sigma^{(\mathrm{a})}\end{array}$ & $\begin{array}{l}\text { PNL-Calcula ted } \\
\text { Results } \pm 10\end{array}$ & Units \\
\hline $\begin{array}{l}{ }^{3} \mathrm{H} \\
3_{\mathrm{H}}^{\mathrm{H}} \\
3_{\mathrm{H}}^{\mathrm{H}} \\
3_{\mathrm{H}}\end{array}$ & $\begin{aligned} 0.0000 & \pm 0.0002(c) \\
0.029 & \pm 0.001 \\
0.29 & \pm 0.01 \\
3.7 & \pm 0.2\end{aligned}$ & $\begin{array}{cl}0.00 & \\
0.0295 & \pm 0.0002 \\
0.301 & \pm 0.002 \\
2.54 & \pm 0.02\end{array}$ & $\begin{aligned} 0.144 & \pm 0.804 \\
12.9 & \pm 0.922 \\
168 & \pm 11.3 \\
1600 & \pm 11.3\end{aligned}$ & $\begin{array}{c}0 \\
11.8 \pm 0.1 \\
154 \pm .21 \\
1490 \pm 11.4\end{array}$ & $\begin{array}{l}\mathrm{nCi} / \mathrm{L} \\
\mathrm{nCi} / \mathrm{L} \\
\mathrm{nCi} / \mathrm{L} \\
\mathrm{nCi} / \mathrm{L}\end{array}$ \\
\hline${ }^{238} \mathrm{Pu}$ & $0.01 \pm 0.01$ & 0.00 & $0.000 \pm 0.007$ & 0 & $\mathrm{PCi} / \mathrm{L}$ \\
\hline${ }^{238}{ }^{23 u} 8_{\mathrm{Pu}}$ & $\begin{array}{l}0.10 \pm 0.01 \\
0.89 \pm 0.03\end{array}$ & $\begin{array}{c}0.107 \pm 0.001 \\
0.93 \pm 0.01\end{array}$ & $\begin{array}{l}0.003 \pm 0.108 \\
0.189 \pm 0.028 \\
0.234 \pm 0.041 \\
0.694 \pm 0.061 \\
0.753 \pm 0.070\end{array}$ & $\begin{array}{l}0 \\
0.182 \pm 0.002 \\
0.190 \pm 0.002 \\
0.721 \pm 0.008 \\
0.742 \pm 0.008\end{array}$ & $\begin{array}{l}\mathrm{PCi} / \mathrm{L} \\
\mathrm{PCi} i \mathrm{~L} \\
\mathrm{pCi} \mathrm{L} \\
\mathrm{pCi} \mathrm{L} \\
\mathrm{pCi} / \mathrm{L}\end{array}$ \\
\hline & $0.00 \pm 0.01$ & 0.00 & $0.008 \pm 0.011$ & 0 & $\mathrm{pCi} / \mathrm{L}$ \\
\hline $241 \mathrm{Am}$ & $0.096 \pm 0.013$ & $0.089 \pm 0.002$ & $\begin{array}{l}0.017 \pm 0.014 \\
0.210 \pm 0.029\end{array}$ & $0.181 \pm 0.003$ & $\begin{array}{l}\mathrm{pCi} / \mathrm{L} \\
\mathrm{pCi} / \mathrm{L}\end{array}$ \\
\hline${ }^{241} \mathrm{Am}$ & $1.00 \pm 0.04$ & $0.91 \pm 0.02$ & $\begin{array}{l}0.219 \pm 0.043 \\
0.790 \pm 0.091 \\
0.800 \pm 0.087\end{array}$ & $\begin{array}{l}0.189 \pm 0.004 \\
0.752 \pm 0.017 \\
0.731 \pm 0.013\end{array}$ & $\begin{array}{l}\mathrm{pCi} / \mathrm{L} \\
\mathrm{pCi} / \mathrm{L} \\
\mathrm{pCi} / \mathrm{L}\end{array}$ \\
\hline $\begin{array}{l}89 \mathrm{Sr} \\
89 \mathrm{Sr} \\
89 \mathrm{Sr}\end{array}$ & & & $\begin{array}{l}\text { (f) } \\
(f) \\
(f)\end{array}$ & $\begin{array}{c}0 \\
36.89 \pm 1.08 \\
108.37 \pm 3.18\end{array}$ & $\begin{array}{l}\mathrm{pCi} / \mathrm{L} \\
\mathrm{pCi} / \mathrm{L} \\
\mathrm{pCi} / \mathrm{L}\end{array}$ \\
\hline $\begin{array}{l}90 \mathrm{Sr} \\
90 \mathrm{Sr} \\
90 \mathrm{Sr}\end{array}$ & $\begin{aligned} 0.05 & \pm 0.13 \\
14.1 & \pm 0.9(d) \\
179 & \pm 11\end{aligned}$ & $\begin{array}{r}0.00 \\
16.9 \pm 0.4 \\
184.5 \pm 4.6\end{array}$ & $\begin{aligned} 0 & \pm 0.32 \\
43.5 & \pm 3.7 \\
112.3 & \pm 9.5\end{aligned}$ & $\begin{array}{r}0 \\
45.7 \pm 1.2 \\
124.1^{2} \pm 3.1\end{array}$ & $\begin{array}{l}\mathrm{PCi} / \mathrm{L} \\
\mathrm{pCi} / \mathrm{L} \\
\mathrm{pCi} / \mathrm{L}\end{array}$ \\
\hline $\begin{array}{l}\operatorname{nat}_{U} \\
\operatorname{nat}_{U} \\
\operatorname{nat}_{U}\end{array}$ & $\begin{aligned} 0.037 & \pm 0.014 \\
7.4 & \pm 0.4 \\
7.24 & \pm 0.02(e) \\
79 & \pm 3\end{aligned}$ & $\begin{array}{l}0.00 \\
7.24 \pm 0.02 \\
-77.8 \pm 0.2\end{array}$ & $\begin{array}{l}1.28 \pm 0.56 \\
15.8 \pm 1.1 \\
50.8 \pm 2.7\end{array}$ & $\begin{aligned} 0 & \\
16.7 & \pm 0.1 \\
52.1 & \pm 0.1\end{aligned}$ & $\begin{array}{l}\mu g / L \\
\mu g / L \\
\mu g / L \\
\mu g / L\end{array}$ \\
\hline $\begin{array}{l}60 \mathrm{Co} \\
60 \mathrm{Co} \\
60 \mathrm{Co} \\
60 \mathrm{Co} \\
60 \mathrm{Co} \\
60 \mathrm{Co} \\
{ }^{\mathrm{Co}}\end{array}$ & & & $\begin{array}{l}<0.012 \\
<0.013 \\
0.216 \pm 0.020 \\
0.238 \pm 0.021 \\
1.060 \pm 0.064 \\
1.130 \pm 0.057\end{array}$ & $\begin{array}{c}0 \\
0 \\
0.202 \pm 0.003 \\
0.230 \pm 0.003 \\
0.980 \pm 0.014 \\
1.158 \pm 0.016\end{array}$ & $\begin{array}{l}\mathrm{nCi} / \mathrm{L} \\
\mathrm{nCi} \mathrm{L} \\
\mathrm{nCi} \mathrm{L} \\
\mathrm{nCi} \mathrm{L} \\
\mathrm{nCi} \mathrm{L} \\
\mathrm{nCi} \mathrm{L}\end{array}$ \\
\hline $\begin{array}{l}137 \mathrm{Cs} \\
137 \mathrm{Cs} \\
137 \mathrm{Cs} \\
137 \mathrm{Cs} \\
137 \mathrm{Cs} \\
137 \mathrm{Cs}\end{array}$ & $\begin{array}{l}<0.01 \\
1.51 \pm 0.04 \\
13.7 \pm 0.1\end{array}$ & $\begin{array}{l}0.00 \\
1.51 \pm 0.02 \\
13.8 \pm 0.2\end{array}$ & $\begin{array}{l}<0.009 \\
<0.010 \\
0.238 \pm 0.018 \\
0.279 \pm 0.019 \\
1.190 \pm 0.064 \\
1.300 \pm 0.064\end{array}$ & $\begin{array}{c}0 \\
0 \\
0.234 \pm 0.004 \\
0.267 \pm 0.004 \\
1.153 \pm 0.018 \\
1.351 \pm 0.021\end{array}$ & $\begin{array}{l}n C i / L \\
n C i / L \\
n C i / L \\
n C i / L \\
n C i / L \\
n C i / L\end{array}$ \\
\hline
\end{tabular}

(a) Results based on analysis of one sample and include estimate of propagated and statistical errors.

(b) Two-step gravimetric dilution of NBS certified standards. Error propagated by methods described i $n$ Appendix $G$.

(c) Tritium results given to $\pm 2 \sigma$.

(d) Significantly different from PNL-calculated results at the $95 \%$ confidence level but not at the 998 confidence level.

(e) Measured at PNL by laser phosphorimetry.

(f) Delayed analysis resulted in sample activity below laboratory MDA at time of analysis due to decay. 


\section{APPROPRIATENESS OF PERFORMANCE CRITERIA}

In evaluating the appropriateness of the performance criteria for radiobioassay in the draft ANSI standard, it is important to consider whether the specified values of AMDA are adequate and reasonable and whether the limits that define the acceptable bias and precision of laboratory measurements are also appropriate. Results of the intercomparison testing program were used to evaluate the performance criteria specified in the draft standard.

\section{MINIMUM DETECTABLE AMOUNT}

The minimum detectable amount (MDA) quantifies the detection capability of a laboratory's analytical method. The draft standard provides acceptable minimum detectable amounts (AMDAs) for several radionuclides. These AMDAs represent activity levels that are important for radiological protection reasons and that are normally considered achievable by bioassay laboratories. Bioassay laboratories should be able to detect the presence in samples of radioactive material at or above the AMDA. When activities are greater than 10 times the AMDA, the laboratory should maintain the relative bias of their results within the range of $-25 \%$ to $+50 \%$ and the relative precision to within $40 \%$.

Each bioassay laboratory should be able to demonstrate that its own MDA is less than or equal to the AMDA The bioassay service laboratory can estimate the MDA using the following equation provided in the draft standard:

$$
\mathrm{MDA}=\frac{4.65 \mathrm{~s}_{\mathrm{b}}+3}{\mathrm{a} \operatorname{RVT}}
$$

where 4.65 = derived factor to limit Type I and II errors to $5 \%$ (Currie 1968)

$$
\begin{aligned}
\mathrm{s}_{\mathrm{b}}= & \text { standard deviation of an appropriate blank } \\
\mathrm{a}= & \text { conversion factor for appropriate units (transformations } \\
& \text { per unit time per unit activity) } \\
\mathrm{E}= & \text { counting efficiency (counts per transformation) }
\end{aligned}
$$




$$
\begin{aligned}
& R=\text { chemical recovery } \\
& V=\text { sample volume } \\
& T=\text { counting time for sample. }
\end{aligned}
$$

This equation utilizes values for sample recovery and counting efficiency that pertain to the measurement of spiked samples. If these values vary appreciably, the lower bound of the $95 \%$ confidence interval for the denominator product should be used.

The MDA for each bioassay laboratory may be estimated in the following way. A testing laboratory uses the analytical results of the control urine samples $^{(a)}$ that contain no added nuclide. These estimates contain actual values for recovery and efficiency that vary as would those of an actual sample. This method is similar to the lower detectable limit (LDL) as defined by Currie (1968). However, these estimates of MDA are determined from a small number of samples and thus may not always be accurate. Both of the above methods can provide a means for checking the stated MDA of a bioassay laboratory. They can also be used to evaluate the appropriateness of AMDA values in the draft standard. These estimates are not, however, useful for testing and certifying the bioassay laboratory's ability to analyze samples at or near the AMDA to the bias and precision criteria specified in the draft standard.

The MDAs calculated using the present form of the MDA equation will be significantly larger than MDAs obtained by the methods of most laboratories. This is true for several reasons. Presently, most laboratories consider only Type I errors (false positives) in their MDA calculations. Thus, using 4.65 instead of 3.0 standard deviations of the blank count increases the calculated MDA by 55\%. Also, the MDA is usually calculated with average values for efficiency, recovery, and other factors. Using the lower bound of the $95 \%$ confidence interval for the product of these factors could increase the calculated MDA by another 50 to $100 \%$. The recommended algorithm technique could then result in an MDA that is three times what is presently reported by a laboratory as their MDA. This should not present a problem if the various aspects of the MDA formula are considered when establishing the AVDA values.

(a) Control samples were not identified. 
Since the geometric means of MDA values for all nuclides except tritium are within a factor of two of the current AMDA values, most laboratories should be able to pass the criterion with minor modifications to procedures. The ANDA values, therefore, appear appropriate for the present capabilities of most participating laboratories. Only the AMDA for tritium appears to be incompatible with laboratory capabilities. The present AMDA is at least 10 times the MDA for $94 \%$ of the participants and 50 times the mean MDA In this case, laboratory capabilities far exceed the apparent health physics need, and a lower AMDA is not required. The distributions of MDAs are illustrated in Figure 10.

One bioassay laboratory requested that the testing levels for ${ }^{3} \mathrm{H}$ be reduced. The reason was that current testing levels were high, compared with measurement capabilities, and the testing laboratory was concerned that contamination from first samples could significantly increase background tritium levels in their low-level counting facility.

\section{RELATIVE BIAS, B $r$}

The relative bias is a measure of the accuracy of the measurement system. It indicates how closely an analysis reports the true activity or amount in samples. It is defined in the draft standard as:

$$
\begin{aligned}
B_{r} & =\text { relative bias } \\
& =\sum_{i=1}^{N} B_{r i} / N
\end{aligned}
$$

where $\quad N=$ the number of samples

$$
\begin{aligned}
& B_{r i}=\text { the bias of a single measurement } \\
& B_{r i}=\left(A_{i}-A_{a j}\right) / A_{a i}
\end{aligned}
$$

where $A_{j}$ is the reported concentration and $A_{a j}$ is the known concentration of the sample. Because the relative bias is an unbiased estimator, it allows comparison of samples at differing concentrations. The draft standard specifies that the relative bias is to be determined by at least five test samples and that bioassay laboratories should achieve a relative bias of 
$-0.25 \leqq B_{r} \leqq+0.50$ when the test activity is at least 10 times the AMDA. At the time the samples were prepared, only three replicate samples were required. Approximately one-third of the participants reported results for which relative bias was outside the recommended limits.

Figures $2,5,7,8$, and 9 show that the mean biases for ${ }^{3} \mathrm{H},{ }^{238} \mathrm{Pu}$, nat ${ }_{\mathrm{U}}$, ${ }^{60} \mathrm{Co}$ and ${ }^{137} \mathrm{Cs}$ were quite small $(<10 \%)$. The individual data for these nuclides show that the analytical results were outside the bias criterion of the standard $(-0.25$ to +0.50$)$ only $9 \%$ of the time. Figures 4 and 6 show the mean relative biases for ${ }^{90} \mathrm{Sr}$ and ${ }^{241} \mathrm{Am}$, both of which were about $-15 \%$. Relative bias failure rates were about $15 \%$ and $20 \%$, respectively. The only nuclide category with a mean relative bias outside the acceptable range specified by draft ANSI Standard $\mathrm{N} 13.30$ was ${ }^{89} \mathrm{Sr}(-36 \%)$, and the relative bias failure rate was $50 \%$ (see Figure 3 ). Analyses for ${ }^{89} \mathrm{Sr}$ in the presence of ${ }^{90} \mathrm{Sr}$ involve complex chemical and mathematical manipulations, which explains why failure rates for ${ }^{89} \mathrm{Sr}$ were high.

If, as was recommended in the pilot study report, the present $B_{r}$ criterion of $-0.25 \leqq B_{r} \leqq+0.50$ were tightened to $-0.20 \leqq B_{r} \leqq+0.20$, the percent failures would increase less than $10 \%$. For most nuclides, this represents the failure of one additional laboratory, on average. The exceptions were ${ }^{90} \mathrm{Sr}$ and natural uranium which would show increases in the percent failure of $29 \%$ and $14 \%$, respectively. The relative bias criterion appears easily achievable by most participating laboratories. Except for strontium and natural uranium, tightening the relative bias criterion to $-0.20 \leqq B_{r} \leqq+0.20$, would have minimal effect on the number of laboratories failing.

RELATIVE PRECISION, $S_{A}$ AND $S_{B}$

The relative precision is a measure of the reproducibility of an analysis. In accordance with the draft standard, it is measured by two separate statistics. The first, $S_{A}$, is defined as the standard deviation of the reported results normalized to the average reported value, expressed as: 


$$
S_{A}=\frac{\left[\sum_{i=1}^{N}\left(A_{i}-\bar{A}\right)^{2} /(N-1)\right]^{\frac{1}{2}}}{\bar{A}}
$$

where $A_{j}$ is the reported concentration and $\bar{A}$ is $\sum A_{j} / N$. This expression may be rearranged and expressed as:

$$
S_{A}=\frac{S_{0}}{-}
$$

where $s_{0}$ is the standard deviation of a series of measurements. The $S_{A}$ equation may also be rearranged to the form:

$$
S_{A}=\left[\sum_{i=1}^{N}\left(\bar{A}_{i} / A-1\right)^{2} /(N-1)\right]^{\frac{1}{2}}
$$

Moving the denominator term inside the summation allows calculation of a single $S_{A}$ over more than one concentration. Likewise, $S_{B}$ is defined as the standard deviation of the bias:

$$
S_{B}=\left[\sum_{i=1}^{N}\left(B_{r i}-B_{r}\right)^{2} /(N-1)\right]^{\frac{1}{2}}
$$

This expression may be rearranged and expressed as:

$$
S_{B}=\frac{S_{0}}{A_{a i}}
$$

where $s_{0}$ is defined as above and $A_{a i}$ is defined as for relative bias. 
The reason for using two statistical indicators is that the relative precision statistic should be independent of relative bias. If errors associated with the analysis are multiplicative in nature (affecting the results by a percentage of the total), only $S_{A}$ is independent of $B_{r}$. However, if errors are additive (affecting any component of the calculation by an absolute amount), $S_{B}$ is independent of $B_{r}$. Because it is impossible to know a priori which situation will predominate, both statistics were specified.

Although the consideration of statistical independence of the criteria was of theoretical importance to the standard developers, $S_{A}$ and $S_{B}$ are nearly equal, and either statistic would be adequate to describe the variability of analysis results. When $B_{r}$ is positive, $S_{A}$ is less than $S_{B}$; when $B_{r}$ is negative, the opposite is true. When $B_{r}$ is zero, $S_{A}$ equals $S_{B}$. $A s$ bias increases, the difference between $S_{A}$ and $S_{B}$ also increases. However, for only 1 of 105 data points did the difference affect whether or not a laboratory passed the relative precision criterion.

The draft standard requires that relative precision be greater than 0.4 when the testing level is at least 10 times AMDA. Of the 144 data points reported, only. 3 were failures of relative precision (2\%). One laboratory failed both $S_{A}$ and $S_{B}$ for ${ }^{89} S r$ and ${ }^{60} C o$, and another laboratory failed only $S_{A}$ for ${ }^{90} \mathrm{Sr}$. The mean relative precisions for all categories, except ${ }^{89} \mathrm{Sr}$, were less than or equal to 0.10 . For ${ }^{89} \mathrm{Sr}$, the mean relative precision was about 0.2 .

The proposed criteria for relative precision $(\leq 0.40)$ appear to be attainable by most participating laboratories at 10 times the AMDA. If either the criteria were lowered to 0.20 for passing or if the testing level were lowered to 2 to 5 times the AMDA, the percent failure would be expected to increase 5 to $10 \%$ based on two rounds of testing.

\section{EVALUATION SUMMARY}

At first glance, the present performance criteria may not appear to be sufficiently rigorous. The data also indicate that some revision of the draft standard criteria for $S_{A}, S_{B}$, and $B_{r}$ would be possible without causing unacceptably high failure percentages. 
According to the calculations of Brodsky (1986), a laboratory must have a true relative precision of $26 \%$ or less in order to pass the criterion with a $95 \%$ probability, based on five replicate sample counts. Likewise, if the true precision of the analytical procedure were actually 0.40 , the laboratory should expect to pass the criterion only $50 \%$ of the time. Implicit in the 0.40 criterion, therefore, is a laboratory capability which greatly exceeds the 0.40 level. Similar probabilities hold for relative bias values. The present acceptance criteria for relative bias and relative precision are therefore adequate.

The present AMDAs appear attainable by the participating laboratories and, with the exception of tritium, do not require revision at this time. The AMDA for tritium ( $100 \mathrm{nCi} / \mathrm{L}$ ) was based on health physics considerations and is 10 times the calculated MDA for $95 \%$ of the participants. Testing at 10 times the AMDA requires samples with at least $1 \mu \mathrm{Ci} / \mathrm{L}$ activity, which is high enough to pose a cross-contamination concern in a low-level analytical laboratory. Reducing the AMDA to $10 \mathrm{nCi} / \mathrm{L}$ mitigates cross-contamination problems without significantly affecting the ability of laboratories to meet the standard. 
As work progressed on this project, frequent discussions took place between members of the project team and members of the Health Physics Society Working Group 2.5 preparing the draft standard. Project representatives attended all meetings of the Working Group to ensure that the intercomparison testing corresponded to the recommendations of the draft standard. Project staff members provided numerous suggestions for improving the draft standard during these meetings. Many of the following recommendations to the committee preparing draft ANSI Standard N13.30 were incorporated or are currently under consideration by the Working Group:

- additional definitions of terms

- procedures for in vivo testing

- procedures for in vitro testing

- selection of categories and radionuclides for both in vitro and in vivo testing

- changes in acceptance criteria

- descriptions of phantoms for in vivo testing (torso, whole-body, and neck phantoms)

- descriptions of quality control procedures

- use of artificial urine and feces test matrices.

- revision of the equation used to calculate $S_{A}$, moving the $\bar{A}$ inside the summation. The present form is:

$$
S_{A}=\left[\sum_{i=1}^{N}\left(\bar{A}_{i} / A-1\right)^{2} /(N-1)\right]^{\frac{1}{2}}
$$

This equation will give numerically equivalent results to the original equation but has the added advantage of allowing calculation of the statistic for more than one testing concentration at a time, in a manner similar to $S_{B}$. 
Specific recommendations formulated in response to results of the in vitro study are:

- retain present acceptance criteria for relative bias and relative precision

- reduce the acceptable MDA for ${ }^{3} \mathrm{H}$ by a factor of 10 to address cross-contamination concerns. 


\section{REFERENCES}

American National Standards Institute (ANSI). 1983. American National Standard for Dosimetry - Personnel Dosimetry Performance - Criteria for Testing. ANSI N13.11, American National Standards Institute, New York, New York.

Attman, P. L., and D. S. Dittmer. 1968. "Metabolism." In Biological Handbook, pp. 521-528. Federation of American Society for Experimental BioTogy, Bethesda, Maryland.

Brodsky, A. 1986. Accuracy and Detection Limits for Bioassay Measurements in Radiation Protection. NUREG/CR-1156, U.S. Nuclear Regulatory Commission, Washington, D.C.

Burns, J. R., and B. Finlayson. 1980. "A Proposal for a Standard Reference Artificial Urine in In Vitro Urolethiasis Experiments." Investigative Urology. 18:167-169.

Bushaw, B. A. 1982. Laser Excitation Kinetic Phosphorimetry for Uranium Analysis. PNL-4557, Pacific Northwest Laboratory, Richland, Washington.

Currie, L. A. 1968. "Limits for Qualitative Detection and Quantitative Determination. Application to Radiochemistry." Analytical Chemistry. $40(3): 586-593$.

Doresmus, R. H., S. Terch, and P. X. Silvis. 1978. "Crystallization of Calcium 0xalate from Synthetic Urine." Investigative Urology. 15:469-472.

Free, A. H., and H. M. Free. 1978. Urinalysis in Clinical Laboratory Practice, pp. 13-19. Chemical Rubber Company Press, Palm Beach, FTorida.

Fuquay, J. J. 1978. Quality Assurance Manual. PNL-MA-65, Pacific Northwest Laboratory, Richland, Washington.

Kanipe, L. G. 1977. Handbook for Analytical Quality Control in Radioanalytical Laboratories. PB-277-254, U.S. Department of Commerce, National Technical Information Service, Springfield, Virginia.

Kelsay, J. L., K. M. Beha11, and E. S. Prather. 1979. "Effect of Fiber from Fruits and Vegetables on Metabolic Responses of Human Subjects. II. Calcium, Magnesium, Iron and Silicon Balances." The American Journal of Clinical Nutrition. 32:1876-1880.

Kenoyer, K. L., K. L. Swinth, A. P. Mileham, R. L. Kathren, and J. M. Selby. 1983. "Evaluation of a Draft Standard on Performance Specifications for Health Physics Instrumentation -- Initial Results for Environmental Tests." Health Physics. 45:227 (Abstract). 
Lentner, C. 1981. "Units of Measurement, Body Fluids, Composition of the Body, Nutrition." In Geigy Scientific Tables, 8th Edition, pp. 469-472. Ciba-Geigy Corporation, West Caldwell, New Jersey.

Long, C. 1961. Biochemists Handbook. Van Nostrand Co. Inc., Princeton, New Jersey.

Nie, N. H., C. H. Hul1, J. G. Jenkins, K. Steinbrenner, and D. H. Bent. 1975. Statistical Package for the Social Sciences. McGraw-Hill Book Company, New York, New York.

Plato, P., and G. Hudson. 1980. Performance Testing of Personnel Dosimetry Services. NUREG/CR-1064, U.S. Nuclear Regulatory Commission, Washington, D.C.

Plato, P., and J. Miklos. 1983. Performance Testing of Personnel Dosimetry Services. NUREG/CR-2891, U.S. Nuclear Regulatory Commission, Washington, D.C.

Roberson, P. L., and K. L. Holbrook. 1984. Guidelines for the Calibration of Personal Dosimeters. PNL-4515, Pacific Northwest Laboratory, Richland, Washington.

Robinson, A. V., D. R. Fisher, and R. T. Hadley. 1984. Performance Testing of Radiobioassay Laboratories: In-Vitro Measurements, Pilot Study Report. NUREG/CR-3809, DOE/NBM 1071, VoT. 1, U.S. Nuclear Regulatory Commission, Washington, D.C.

Selby, J. M., J. L. Kenoyer, K. L. Swinth, and R. L. Kathren. 1983. "Evaluation of a Draft Standard on Performance Specifications for Health Physics Instrumentation--Program Overview." Health Physics. 45:227 (Abstract).

Swinth, K. L., J. L. Kenoyer, A. P. Mileham, R. L. Kathren, and J. M. Selby. 1983. "Evaluation of a Draft Standard on Performance Specifications for Health Physics Instrumentation--Initial Results for Radiological Tests." Health Physics. 45:227 (Abstract).

Yoder, R. C., W. T. Bartlett, J. W. Courtney, C. D. Hooker; J. A. Holland, and B. T. Hogan. 1979. Confirmation of Conversion Factors Relating Exposure and Dose-Equivalent Index Presented in ANSI N13.11. NUREG/CR-1057, PNL-3219, Pacific Northwest Laboratory, Richland, Washington. 
APPENDIX A

SAMPLE LETTER, TEST CATEGORIES, AND MDA ESTIMATE FORM 


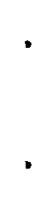


APPENDIX A

SAMPLE LETTER

REQUEST FOR ESTIMATED MDA AND ERROR

February 23, 1982

Dear

RE: Technical Evaluation of Draft ANSI Standard N13.30.

Thank you for responding to our recent invitation to participate in a bioassay intercomparison study to evaluate the performance criteria contained in draft ANSI Standard 13.30. The draft Standard is currently being revised and there may be some additional changes in the choice of test radionuclides and testing ranges. For example, we are currently anticipating the nuclides and ranges shown in Table I. You may notice that we have deleted $226 \mathrm{Ra}$ and the category of gross alpha measurements. In addition, we plan to mix $238 \mathrm{Pu}$ with $241 \mathrm{Am}$, and ${ }^{137} \mathrm{Cs}$ with ${ }^{90} \mathrm{Sr}$ in the samples sent out for assay.

The purposes of this program are to evaluate the appropriateness of performance criteria in draft ANSI Standard 13.30, "Performance Criteria for Radiobioassay," and to measure the performance of existing bioassay laboratories against the criteria specified in that draft standard. The end result of the program will be a manual detailing procedures and criteria by which laboratories providing bioassay services will be "accredited."

We would appreciate your estimate of a minimum detectable activity (MDA) and its associated standard deviation for each nuclide for which you wish to qualify. Please use the attached form. We would also request an estimation of uncertainty for the other three levels of activity listed on the attached sheet. The cumulative data will be used to guide in selection of final 
February 23, 1982

Page 2

testing levels, numbers of samples, and for further evaluation of acceptable minimum detectable activity (AMDA) in the draft ANSI standard. Each response wi 11 be held in strictest confidence.

We are planning to use artificial urine in this project. The artificial urine will contain inorganic and biological constituents. If you have comments regarding this option, we would greatly appreciate them. Please try to be specific in your criticism or support.

We feel that your cooperation is essential to the development of a good accreditation procedure and the best possible standard.

Very truly yours, 
TABLE A.1. In-Vitro Testing Categories, Radionuclides, and Testing Range

\begin{tabular}{|c|c|c|c|}
\hline Procedure & Radionuclide & \multicolumn{2}{|c|}{ Range } \\
\hline Liquid scintillation & & $2.0-200$ & $\mu \mathrm{Ci} / \mathrm{L}$ \\
\hline Alpha spectrometry & ${ }^{241} \mathrm{Am}$ & $0.06-6.0$ & $\mathrm{pCi} / \mathrm{L}$ \\
\hline & ${ }^{238} \mathrm{Pu}$ & $0.05-5.0$ & $\mathrm{pCi} / \mathrm{L}$ \\
\hline Beta measurements & ${ }^{90} \mathrm{Sr}$ & $0.01-1.0$ & $\mathrm{nCi} / \mathrm{L}$ \\
\hline Fluorescence measurements & $\operatorname{nat}_{U}$ & $5.0-500$ & $\mu \mathrm{g} / \mathrm{L}$ \\
\hline Gamma spectrometry & ${ }^{137} \mathrm{Cs}$ & $0.04-4.0$ & $\mathrm{nCi} / \mathrm{L}$ \\
\hline
\end{tabular}


Return to:

Pacific Northwest Laboratory Health Physics Technology

Richland, WA 99352

Nuclide

AMDA suggested by Draft ANSI N13.30=

Estimated $M D A \pm 1 \sigma=$

Count time

MDA = minimum detectable activity

$=\frac{4.65 \mathrm{~s}_{b}}{E R V K}$

$s_{b}=$ standard deviation of appropriate blank

$E$ = counting efficiency expressed as a decimal

$R=$ recovery expressed as a decimal

$V=$ sample size

$=$

$=$

$K=$ conversion factor to convert dpm to appropriate units

1. $A M D A \pm 1 \sigma=$

Count time

2. $20 \mathrm{AMDA} \pm 1 \sigma=$ Count time

3. $100 \mathrm{AMDA} \pm 1 \sigma=$ Count time

Comments: artificial urine, proposed AMDA, other. 


\section{APPENDIX B}

SAMPLE PREPARATION PROCEDURE 


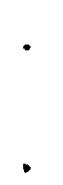

. 
APPENDIX B

\section{SAMPLE PREPARATION PROCEDURE}

\section{BOTTLE PREPARATION, FILLING AND SHIPPING}

1. All bottles and caps (50-L carboys, 2-L and 250-mL bottles) are filled with a $4 \%$ solution of Radiacwash ${ }^{(1)}$ and allowed to soak for 24 hours or more.

2. The bottles and caps are rinsed exhaustively with tap water, followed by two rinses with deionized water. The deionized water is prepared by passing tap water through a purification system consisting of a 20- $\mu$ m prefilter cartridge followed by a mixed bed ion exchange cartridge, a charcoal cartridge, and finally a 5-um scrubbing cartridge.

3. The bottles and caps are then air dried. To guard against dust particles falling into the bottles, they are either laid on their sides or covered with paper towels during drying.

4. After the bottles have dried, the caps are screwed on the bottles and the labels prepared and affixed as below.

5. The labels for the bottles are prepared and taped on the bottles. The labels are standard adhesive-backed paper. The labels are covered with a strip of clear $2 \frac{1}{2}$-inch tape to further protect the information on them.

6. The capped, labeled bottles are then weighed to $\pm 0.015-\mathrm{g}$ accuracy on a top loading balance.

7. Aliquots of spiked artificial urine are then delivered to each bottle, as described below (steps 8-16). Procedures for preparing the spiked artificial urine are discussed in Section II.

(B) Atomic Products Corp., Center Moriches, New York. 
8. The 50-L carboy of spiked artificial urine is positioned near a sample dispensing apparatus consisting of a peristaltic pump, speed control and a handheld remote switch. The supply tubing is placed in the 50-L carboy and 1300-1400 mL (or appropriate volume) of sample are delivered to each bottle.

9. Each bottle is immediately capped and reweighed to the nearest $\pm 0.15 \mathrm{~g}$ on a top-loading electronic balance. After weighing, a 11 caps are taped to the neck of the bottle with stretch vinyl tape.

10. All weights are recorded in the laboratory notebook, or the balance printout tape is affixed to the notebook.

11. The bottles and laboratories are randomly selected by drawing numbered chits from a container.

12. The assigned sample bottles are then placed in $9 \frac{1}{2}$ in. by $9 \frac{1}{2}$ in. by 12 in. DOT approved boxes (type 12B), 3 bottles to a box. Vermiculite is poured around each bottle until the box is full. The bottles are lifted slightly to ensure that there is a layer of vermiculite beneath them.

13. The following sheets are inserted in each box:

a. Instructions to Laboratories

b. QA/QC Guidelines

c. Data Report Sheets.

14. The box is taped securely shut and shipped after the following labels are affixed:
a. Address Label
b. Corrosive Liquids Label (NOS 1760)
c. Corrosive Liquids Label (diamond shape)
d. "This Side Up" Label.

15. One sample from each radionuclide batch (50-L carboy) is sent to an analytical laboratory for confirmation of calculated dilution.

16. The remaining samples (7-8 from each level) are stored in the laboratory. 
II. PREPARATION OF SPIKED ARTIFICIAL URINE

1. Verify the presence of a valid calibration label on all balances to be used.

2. Place a 1-in. by 6-in. magnetic stirring bar in the carboy and tare weigh the carboy, bar, and caps. Ensure that there are 13 to 16 inches of nonmagnetic material between the magnetic stirring bar in the bottom of the carboy and top of the balance. This is necessary to alleviate disturbances in the accuracy of the balance because of the magnetic field from the stirring bar.

3. Place about $35 \mathrm{~kg}$ of water in a 50-L carboy. Record the weight of the added water in the laboratory notebook (or use the printer tape).

4. Start the magnetic stirrer and add the various components of the artificial urine while stirring. Record all sample and tare weights in the laboratory notebook (or use printer tape).

5. Calculate the quantity of $50 \%$ concentrated nitric acid to be added so that the final calculated concentration of acid will be equivalent to $50 \mathrm{~g}$ of concentrated $(70 \%) \mathrm{HNO}_{3}$ per liter of solution, or approximately $0.55 \mathrm{M}$ following addition of radionuclide standard.

6. Add the appropriate diluted NBS-supplied standard spike (see Section III for details), and calculate the weight of water and acid still required as shown below for a $50-\mathrm{kg}$ batch:

$$
w_{w a}=50 \mathrm{~kg}-\left[w_{u}+w_{w}+w_{s}+w_{a a}\right] \text {. }
$$

where $w_{a a}=2.5 \mathrm{~kg}-\left[0.5 w_{a}+0.5 w_{s}\right]$

$W_{u}=$ weight of artificial urine constituents $(\mathrm{kg})$

$W_{W}=$ weight of water previously added $(\mathrm{kg})$

$W_{S}=$ weight of standard spike $(\mathrm{kg})$

$W_{a}=$ weight of acid added in step $5(\mathrm{~kg})$

$W_{\text {wa }}=$ weight of water to be added $(\mathrm{kg})$

$W_{a a}=$ weight of acid to be added after spike 
7. Add $W_{a a}$ and approximately $95 \%$ of the water required $W_{w a}$ and stir for 30 minutes.

8. Use the floor crane to lift the carboy from the magnetic stirrer to the $60-\mathrm{kg}$ top-loading balance and add water until the final weight $\left(W_{f}\right)$ of the carboy contents reaches $50 \mathrm{~kg}( \pm 1.5 \mathrm{~g})$.

9. Remove the carboy from the balance, and place it on the magnetic stirrer. Stir vigorously for at least 30 minutes before dispensing samples.

III. PREPARATION OF NBS STANDARD SPIKE FOR ADDITION TO ARTIFICIAL URINE

1. Dilutions are performed in 2-L polyethylene bottles which have been washed and dried as previously discussed (Section I).

2. Calculate the amount of NBS standard to be added to the dilution bottle as below:

$$
w_{S a}=\frac{\left(C_{F D}\right)\left(W_{F D}\right)}{\left(C_{S}\right)}
$$

where $W_{\text {sa }}=$ Appropriate weight $(g)$ of the NBS standard to be added to the dilution bottle.

$W_{F D}=$ Final desired weight (usually $50 \mathrm{~kg}$ ) of total spiked artificial urine batch.

$C_{F D}=$ Final desired nuclide concentration in artificial urine (activity or mass/kg).

$c_{s}=$ Concentration of nuclide in NBS supplied standard (activity or mass/g).

3. Add a $50 \%$ solution of concentrated nitric acid ( $35 \%$ actual $\mathrm{HNO}_{3}$ concentration) to the polyethylene dilution bottle according to the following equation:

$$
W_{a}=1000 g-W_{s a}
$$


where $W_{a}$ is the weight of acid solution to add $(g)$ and $w_{s a}$ is the calculated weight of NBS Standard to be added to artificial urine (g).

4. Open enough NBS Standard vials to provide sufficient nuclide and aspirate the standard solution into a disposable Reservial. ${ }^{\circledR}$

5. Weigh the vial and standard and dispense the calculated weight $\left(W_{\text {sa }}\right)$ of standard in the polyethylene bottle.

6. Cap the bottle and mix thoroughiy.

7. Weigh the bottle and pour the contents into a batch of artificial urine. Reweigh the bottle to calculate the exact amount of standard delivered $\left(w_{s d}\right)$.

8. Calculate the final actual concentration of nuclide added to the carboy as below:

$$
C_{F C}=\frac{\left(w_{s d}\right)\left(C_{s}\right)}{\left(w_{f}\right)}
$$

where $C_{F C}=$ Final calculated nuclide concentration in artificial urine (activity or mass per $\mathrm{kg}$ ).

$W_{s d}=$ Weight of NBS Standard delivered to the artificial urine $(g)$.

$W_{f}=$ Final weight of carboy contents from Step 8 Section II.

$C_{S}=$ Concentration of nuclide in NBS-supplied Standard (activity or mass per $\mathrm{g}$ ).

- Disposable plastic ampule, Perfector Scientific, Atascadero, California. 


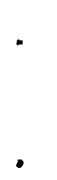


APPENDIX C

INSTRUCTIONS TO PARTICIPATING IN VITRO LABORATORIES 


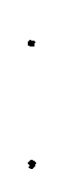


APPENDIX C

INSTRUCTIONS TO PARTICIPATING IN VITRO LABORATORIES

1. Log in the receipt of samples and send a list of samples received to PNL. Samples will be labeled with an identification number in the following format:

$$
\text { A-Sr-0001-7356-32 }
$$

where

$$
\begin{aligned}
A & =\text { Laboratory code }(A, B, C, D, \text { etc. }) \\
S r & =\text { Strontium or other nuclide } \\
0001 & =\text { Sample identification number 0001-9999 } \\
7356-32 & =\text { PNL identification number. }
\end{aligned}
$$

2. The date on the label of each bottle is the date that the nuclide was added to the urine, and all data should be decay-corrected to that date, if necessary.

3. Use the identification number in all subsequent bookkeeping and correspondence.

4. Send complete analytical procedures including QA, wet chemistry, counting, and data reduction to PNL for review.

5. Report measurement results within 30 days after receipt of samples and use the report sheets provided.

6. PNL will send to participants the summary sheets containing results of a11 participating laboratories, following receipt of data.

7. The identity of participating laboratories and the content of any procedures sent to PNL will not be revealed to any person or agency of the government or private sector without the prior consent of the participant. 


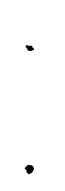

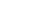


APPENDIX D

IN VITRO MEASUREMENTS REPORT FORM 


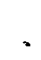

. 


\section{IN VITRO MEASUREMENTS REPORT FORM}

Nucl ide

Sample Preparation Date

Name of Laboratory and/or Code Letter

Contact Person

Phone ( )

Date of Receipt

Date of Analysis

Method of Storage:

Sample Manipulations:

Analytic Method:

Apparatus/Instrumentation Used:

\begin{tabular}{llllllll}
\hline $\begin{array}{c}\text { Sample } \\
\text { No. }\end{array}$ & $\begin{array}{l}\text { Total } \\
\text { Counts }\end{array}$ & $\begin{array}{l}\text { Count } \\
\text { Time }\end{array}$ & $\begin{array}{l}\text { Background } \\
\text { Count Rate }\end{array}$ & $\begin{array}{c}\text { Counting } \\
\text { Efficiency }\end{array}$ & Recovery & $\begin{array}{l}\text { Sample } \\
\text { Assay }\end{array}$ & $\begin{array}{l}\text { Est. } \\
\text { Error }\end{array}$ \\
\hline
\end{tabular}

$\square$

i

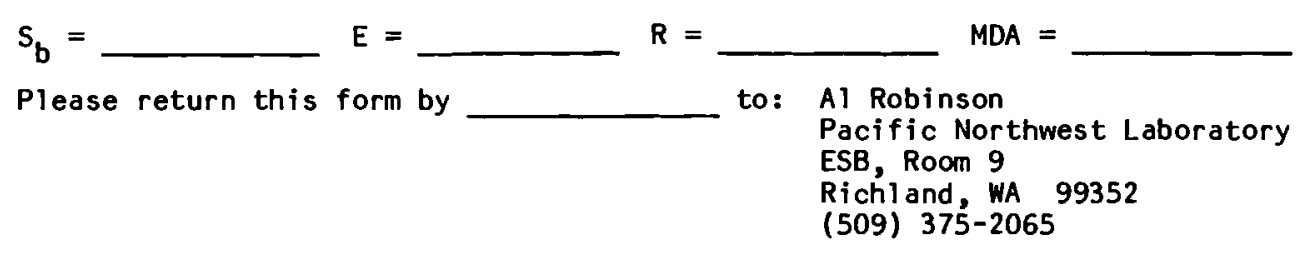


1. Method of Storage - room temperature, frozen, etc.

2. Sample Manipulations - addition of acid, division of sample, etc.

3. Analytical Method - brief description, or reference the procedure submitted previously to PNL. Indicate differences from routine procedure, if any.

4. Data - do not round off.

5. Count time - minutes.

6. Estimated Error - total error due to counting statistics, systematic errors, and error propagated during calculation of efficiency, recovery, etc.

7. Units - $\mu \mathrm{Ci} / \mathrm{L}$ or $\mathrm{pC} i / \mathrm{L}$ for radionuclides; $\mu \mathrm{g} / \mathrm{L}$ for natural uranium.

8. MDA (Minimum Detectable Activity) - defined in draft ANSI Standard N13.30 as

$$
M D A=\frac{4.65 s_{b}}{E R V R}
$$

where $s_{b}=$ standard deviation of appropriate blank

$E$ = counting efficiency expressed as a decimal fraction

$R=$ recovery, expressed as a decimal fraction

$V=$ sample size

$K=$ conversion factor to convert to appropriate units

$4.65=$ derived factor to 1 imit type I and II errors.

Note: The MDA is not to be determined by these sample analyses, but rather is to be derived from previous laboratory experience. 
APPENDIX E

DETERMINATION OF MINIMUM DETECTABLE AMOUNTS 


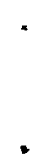

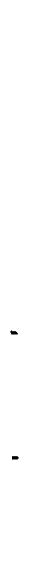




\section{APPENDIX E}

\section{DETERMINATION OF MINIMUM DETECTABLE AMOUNTS}

The standard method of Currie (1968) was used to predict the minimum detectable amount based solely on the standard deviation of the control sample.

Type 1 and type 2 errors ( $\alpha$ and $\beta$ ) were assumed equal, and random errors were assumed normally distributed. Also, the standard deviation of the signal at the detection point was assumed equal to the standard deviation of the control, such that

$$
\begin{aligned}
& \text { if } \alpha=\beta=67 \%, \text { then MDA }=2.32 \sigma \\
& \text { if } \alpha=\beta=95 \%, \text { then MDA }=4.65 \sigma \\
& \text { if } \alpha=\beta=99 \%, \text { then MDA }=6.98 \sigma
\end{aligned}
$$

In addition, this estimate assumed that blanks and samples are counted for the same period of time. To generate the data in Table 4 (page 12), $\alpha=\beta=95 \%$ was chosen. Then, for al1 nuclides except ${ }^{89} \mathrm{Sr}$ and natural uranium

$$
M D A=\frac{4.65 \sigma_{C}+3}{a E R V T}
$$

where $\sigma_{C}=$ one standard deviation of the control sample counts

$\mathrm{a}=$ conversion factor for transformation to $\mathrm{pCi}$ or $\mathrm{nCi}$

$E=$ efficiency, counts per transformation

$\mathrm{R}=$ chemical recovery

$V=$ sample volume

$T=$ count time.

The " 3 " in the equation is used to estimate MDA when $\sigma_{c}$ is negligible. Under this assumption, at least 3 counts from the sample would be necessary to 1 imit type 2 errors (false negatives) to $5 \%$. If a 11 factors necessary to calculate MDA were not reported, the result was recorded as inadequate data (I/D). 
The above equation is not appropriate for ${ }^{89} \mathrm{Sr}$ or natural uranium. Natural uranium is measured by fluorometric methods giving a measurement current rather than describing counts. For ${ }^{89} \mathrm{Sr}$, a more complicated procedure is necessary to account for ${ }^{90} \mathrm{Sr}$ content. For both nuclides, the standard deviation of the test results was used and the equation simplified to:

$$
M D A=4.65 \sigma_{a}
$$

where $\sigma_{a}$ is the standard deviation of the assay values. 


\section{APPENDIX $F$}

IN VITRO BIOASSAY RESULTS 


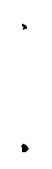

- 


\section{DEFINITION OF TERMS}

a. $A_{a i}=$ "true" concentration

b. MDA = "Minimum Detectable Amount," as calculated by PNL. MDA(1) is estimated from the reported counts for the five replicate blank samples with the equation

$$
\text { MDA }=\frac{4.65 \mathrm{~s}_{B}+3}{R}
$$

where $K$ equals the calibration factor necessary to convert counts to the desired concentration units. MDA(2) is estimated from the reported assays for the five replicate blank counts from the equation

$$
\text { MDA }=4.65 \mathrm{~s}_{B}
$$

where $s_{B}$ is the standard deviation of the five replicate assays.

c. $A M D A=$ "Acceptable Minimum Detectable Amount," as defined by draft ANSI Standard N13.30.

d. $B_{r}=$ Relative Bias, as defined by draft ANSI Standard N13.30.

e. $S_{A}$ and $S_{B}=$ Relative Precision estimators, as defined by draft ANSI Standard N13.30.

f. $I / D=$ inadequate data to calculate

g. Standard Criteria

$$
-0.25 \leqq B_{r} \leqq 0.50
$$

$S_{A}$ and $S_{B} \leqq 0.40$

$M D A \leqq A M D A$ 
TABLE F.1. ${ }^{3} \mathrm{H}$ Relative Bias and Precision, and MDA (AMDA $=100 \mathrm{nCi} / \mathrm{L}$ )

\begin{tabular}{|c|c|c|c|c|c|c|c|}
\hline \multirow[b]{2}{*}{ Round } & \multirow[b]{2}{*}{$\underline{L a b}$} & \multirow{2}{*}{$\begin{array}{r}\mathrm{A}_{\mathrm{a} i}, \\
\mathrm{nC} \mathrm{i} / \mathrm{L}\end{array}$} & \multirow[b]{2}{*}{${ }^{B} r$} & \multirow[b]{2}{*}{$S_{B}$} & \multirow[b]{2}{*}{$S_{A}$} & \multicolumn{2}{|c|}{$\mathrm{MDA}, \mathrm{nCi} / \mathrm{L}$} \\
\hline & & & & & & $\operatorname{MDA}(1)$ & $\operatorname{MDA}(2)$ \\
\hline One & G & $\begin{array}{l}2.95 \mathrm{E}+01 \\
3.01 \mathrm{E}+02 \\
\text { Subtota } 1 \text { * } \\
\text { 3.54E+03 } \\
\text { Tota } 1\end{array}$ & $\begin{array}{l}-1.66 \mathrm{E}-02 \\
-2.39 \mathrm{E}-02 \\
-2.10 \mathrm{E}-02 \\
-2.73 \mathrm{E}-02 \\
-2.34 \mathrm{E}-02\end{array}$ & $\begin{array}{l}3.16 \mathrm{E}-02 \\
9.10 \mathrm{E}-03 \\
1.75 \mathrm{E}-02 \\
1.81 \mathrm{E}-02 \\
1.67 \mathrm{E}-02\end{array}$ & $\begin{array}{l}3.22 \mathrm{E}-02 \\
9.33 \mathrm{E}-03 \\
1.74 \mathrm{E}-02 \\
1.86 \mathrm{E}-02 \\
1.65 \mathrm{E}-02\end{array}$ & $\mathrm{I} / \mathrm{D}$ & $\mathrm{I} / \mathrm{D}$ \\
\hline One & J & $\begin{array}{l}2.95 E+01 \\
3.01 E+02 \\
\text { Subtota } 1 \\
3.54 E+03 \\
\text { Total }\end{array}$ & $\begin{array}{l}2.77 \mathrm{E}-01 \\
1.85 \mathrm{E}-01 \\
2.31 \mathrm{E}-01 \\
1.97 \mathrm{E}-01 \\
2.20 \mathrm{E}-01\end{array}$ & $\begin{array}{l}1.04 \mathrm{E}-01 \\
1.92 \mathrm{E}-02 \\
8.35 \mathrm{E}-02 \\
7.11 \mathrm{E}-03 \\
6.83 \mathrm{E}-02\end{array}$ & $\begin{array}{l}8.11 \mathrm{E}-02 \\
1.62 \mathrm{E}-02 \\
5.23 \mathrm{E}-02 \\
5.94 \mathrm{E}-03 \\
4.15 \mathrm{E}-02\end{array}$ & $5.81 E+00$ & $5.64 \mathrm{E}+00$ \\
\hline One & K & $\begin{array}{l}2.95 E+01 \\
3.01 E+02 \\
\text { Subtota } 1 \\
3.54 E+03 \\
\text { Total }\end{array}$ & $\begin{array}{l}-2.21 \mathrm{E}-01 \\
-2.45 \mathrm{E}-01 \\
-2.33 \mathrm{E}-01 \\
-2.41 \mathrm{E}-01 \\
-2.36 \mathrm{E}-01\end{array}$ & $\begin{array}{l}1.45 \mathrm{E}-02 \\
8.16 \mathrm{E}-03 \\
1.69 \mathrm{E}-02 \\
4.21 \mathrm{E}-03 \\
1.40 \mathrm{E}-02\end{array}$ & $\begin{array}{l}1.86 \mathrm{E}-02 \\
1.08 \mathrm{E}-02 \\
1.36 \mathrm{E}-02 \\
5.54 \mathrm{E}-03 \\
1.11 \mathrm{E}-02\end{array}$ & $I / D$ & $1.58 \mathrm{E}+00$ \\
\hline One & $\mathrm{L}$ & $\begin{array}{l}2.90 \mathrm{E}+01 \\
3.01 \mathrm{E}+02 \\
\text { Subtota } 1 \\
3.54 \mathrm{E}+03 \\
\text { Total }\end{array}$ & $\begin{array}{l}-6.34 \mathrm{E}-02 \\
-3.96 \mathrm{E}-02 \\
-4.75 \mathrm{E}-02 \\
-5.46 \mathrm{E}-02 \\
-5.11 \mathrm{E}-02\end{array}$ & $\begin{array}{l}\text { Insufficie } \\
1.83 \mathrm{E}-02 \\
1.89 \mathrm{E}-02 \\
8.36 \mathrm{E}-02 \\
5.44 \mathrm{E}-02\end{array}$ & $\begin{array}{l}\text { nt Data } \\
1.91 \mathrm{E}-02 \\
1.35 \mathrm{E}-02 \\
8.85 \mathrm{E}-02 \\
5.66 \mathrm{E}-02\end{array}$ & $2.99 E-02$ & $2.69 E-02$ \\
\hline One & M & $\begin{array}{l}2.90 E+01 \\
3.01 E+02 \\
\text { Subtotal } \\
3.54 E+03 \\
\text { Total }\end{array}$ & $\begin{array}{r}3.62 \mathrm{E}-02 \\
-2.59 \mathrm{E}-02 \\
5.15 \mathrm{E}-03 \\
-1.31 \mathrm{E}-02 \\
-9.47 \mathrm{E}-04\end{array}$ & $\begin{array}{l}2.68 \mathrm{E}-02 \\
1.41 \mathrm{E}-03 \\
3.91 \mathrm{E}-02 \\
4.19 \mathrm{E}-03 \\
3.18 \mathrm{E}-02\end{array}$ & $\begin{array}{l}2.59 \mathrm{E}-02 \\
1.45 \mathrm{E}-03 \\
1.50 \mathrm{E}-02 \\
4.25 \mathrm{E}-03 \\
1.17 \mathrm{E}-02\end{array}$ & $3.49 E+00$ & $3.36 E+00$ \\
\hline One & $N$ & $\begin{array}{l}2.90 \mathrm{E}+01 \\
3.01 \mathrm{E}+02 \\
\text { Subtota } 1 \\
3.54 \mathrm{E}+03 \\
\text { Total } 1\end{array}$ & $\begin{array}{r}-1.49 \mathrm{E}-01 \\
-2.21 \mathrm{E}-02 \\
-8.58 \mathrm{E}-02 \\
9.42 \mathrm{E}-04 \\
-5.69 \mathrm{E}-02\end{array}$ & $\begin{array}{l}8.68 \mathrm{E}-02 \\
1.07 \mathrm{E}-02 \\
8.90 \mathrm{E}-02 \\
1.63 \mathrm{E}-02 \\
8.30 \mathrm{E}-02\end{array}$ & $\begin{array}{l}1.02 \mathrm{E}-01 \\
1.09 \mathrm{E}-02 \\
6.49 \mathrm{E}-02 \\
1.63 \mathrm{E}-02 \\
5.19 \mathrm{E}-02\end{array}$ & $I / D$ & $0.00 E+00$ \\
\hline One & $\mathrm{S}$ & $\begin{array}{l}2.90 E+01 \\
3.01 E+02 \\
\text { Subtota } 1 \\
3.54 E+03 \\
\text { Total }\end{array}$ & $\begin{array}{l}-2.02 \mathrm{E}-02 \\
-6.16 \mathrm{E}-02 \\
-4.09 \mathrm{E}-02 \\
-5.02 \mathrm{E}-02 \\
-4.40 \mathrm{E}-02\end{array}$ & $\begin{array}{l}1.87 \mathrm{E}-02 \\
8.99 \mathrm{E}-03 \\
2.62 \mathrm{E}-02 \\
3.89 \mathrm{E}-03 \\
2.13 \mathrm{E}-02\end{array}$ & $\begin{array}{l}1.91 \mathrm{E}-02 \\
9.58 \mathrm{E}-03 \\
1.35 \mathrm{E}-02 \\
4.09 \mathrm{E}-03 \\
1.09 \mathrm{E}-02\end{array}$ & $6.36 \mathrm{E}-01$ & $6.94 \mathrm{E}-01$ \\
\hline
\end{tabular}

* Subtotal is the composite statistic for the two lower test concentrations. 
TABLE F.1. (Contd)

\begin{tabular}{|c|c|c|c|c|c|c|c|}
\hline \multirow[b]{2}{*}{ Round } & \multirow[b]{2}{*}{$\underline{\text { Lab }}$} & \multirow{2}{*}{$\begin{array}{c}\mathrm{A}_{\mathrm{ai}}, \\
\mathrm{nCi} \mathrm{L} / \mathrm{L}\end{array}$} & \multirow[b]{2}{*}{$\mathrm{B}_{r}$} & \multirow[b]{2}{*}{$S_{B}$} & \multirow[b]{2}{*}{$S_{A}$} & \multicolumn{2}{|c|}{$\mathrm{MDA}, \mathrm{nCi} / \mathrm{L}$} \\
\hline & & & & & & $\operatorname{MDA}(1)$ & $\operatorname{MDA}(2)$ \\
\hline One & V & $\begin{array}{l}2.90 E+01 \\
3.01 E+02 \\
\text { Subtota } 1 \\
3.54 E+03 \\
\text { Tota } 1\end{array}$ & $\begin{array}{l}-3.92 \mathrm{E}-02 \\
-8.24 \mathrm{E}-02 \\
-6.08 \mathrm{E}-02 \\
-6.85 \mathrm{E}-02 \\
-6.34 \mathrm{E}-02\end{array}$ & $\begin{array}{l}2.37 \mathrm{E}-02 \\
6.15 \mathrm{E}-03 \\
2.83 \mathrm{E}-02 \\
7.80 \mathrm{E}-03 \\
2.30 \mathrm{E}-02\end{array}$ & $\begin{array}{l}2.46 \mathrm{E}-02 \\
6.70 \mathrm{E}-03 \\
1.61 \mathrm{E}-02 \\
8.38 \mathrm{E}-03 \\
1.34 \mathrm{E}-02\end{array}$ & $1.12 \mathrm{E}+00$ & $9.68 \mathrm{E}-02$ \\
\hline Two & $A D$ & $\begin{array}{l}1.17 E+01 \\
1.54 E+02 \\
\text { Subtota } 1 \\
1.49 E+03 \\
\text { Tota } 7\end{array}$ & $\begin{array}{l}2.13 \mathrm{E}-02 \\
1.21 \mathrm{E}-02 \\
1.67 \mathrm{E}-02 \\
9.83 \mathrm{E}-03 \\
1.44 \mathrm{E}-02\end{array}$ & $\begin{array}{l}1.41 \mathrm{E}-01 \\
7.01 \mathrm{E}-02 \\
9.95 \mathrm{E}-02 \\
4.94 \mathrm{E}-02 \\
8.25 \mathrm{E}-02\end{array}$ & $\begin{array}{l}1.38 \mathrm{E}-01 \\
6.93 \mathrm{E}-02 \\
9.75 \mathrm{E}-02 \\
4.89 \mathrm{E}-02 \\
8.09 \mathrm{E}-02\end{array}$ & $1.12 \mathrm{E}-01$ & $9.40 \mathrm{E}-02$ \\
\hline Two & $A E$ & $\begin{array}{l}1.17 E+01 \\
1.54 E+02 \\
\text { Subtota } 1 \\
1.49 E+03 \\
\text { Tota } 7\end{array}$ & $\begin{array}{l}-3.91 \mathrm{E}-02 \\
-5.81 \mathrm{E}-02 \\
-4.86 \mathrm{E}-02 \\
-5.45 \mathrm{E}-02 \\
-5.06 \mathrm{E}-02\end{array}$ & $\begin{array}{l}2.18 \mathrm{E}-02 \\
2.96 \mathrm{E}-02 \\
2.55 \mathrm{E}-02 \\
8.64 \mathrm{E}-03 \\
2.08 \mathrm{E}-02\end{array}$ & $\begin{array}{l}2.27 \mathrm{E}-02 \\
3.14 \mathrm{E}-02 \\
2.45 \mathrm{E}-02 \\
9.14 \mathrm{E}-03 \\
1.99 \mathrm{E}-02\end{array}$ & $9.90 \mathrm{E}-02$ & $5.45 \mathrm{E}-01$ \\
\hline Two & $A G$ & $\begin{array}{l}1.17 E+01 \\
1.54 E+02 \\
\text { Subtota } 1 \\
1.49 E+03 \\
\text { Tota } 1\end{array}$ & $\begin{array}{l}-2.70 \mathrm{E}-02 \\
-7.14 \mathrm{E}-02 \\
-4.92 \mathrm{E}-02 \\
-9.14 \mathrm{E}-02 \\
-6.33 \mathrm{E}-02\end{array}$ & $\begin{array}{l}3.02 \mathrm{E}-02 \\
3.99 \mathrm{E}-02 \\
4.00 \mathrm{E}-02 \\
6.28 \mathrm{E}-02 \\
4.93 \mathrm{E}-02\end{array}$ & $\begin{array}{l}3.11 \mathrm{E}-02 \\
4.30 \mathrm{E}-02 \\
3.35 \mathrm{E}-02 \\
6.91 \mathrm{E}-02 \\
4.36 \mathrm{E}-02\end{array}$ & $6.99 \mathrm{E}+01$ & $3.48 \mathrm{E}+01$ \\
\hline Two & $\mathrm{AH}$ & $\begin{array}{l}1.17 \mathrm{E}+01 \\
1.54 \mathrm{E}+02 \\
\text { Subtota } 1 \\
1.49 \mathrm{E}+03 \\
\text { Total }\end{array}$ & $\begin{array}{l}3.13 \mathrm{E}-01 \\
7.07 \mathrm{E}-02 \\
1.92 \mathrm{E}-01 \\
6.79 \mathrm{E}-02 \\
1.51 \mathrm{E}-01\end{array}$ & $\begin{array}{l}1.20 \mathrm{E}-01 \\
2.28 \mathrm{E}-02 \\
1.54 \mathrm{E}-01 \\
2.05 \mathrm{E}-02 \\
1.37 \mathrm{E}-01\end{array}$ & $\begin{array}{l}9.17 \mathrm{E}-02 \\
2.13 \mathrm{E}-02 \\
5.96 \mathrm{E}-02 \\
1.92 \mathrm{E}-02 \\
4.80 \mathrm{E}-02\end{array}$ & $6.07 E+00$ & $6.77 \mathrm{E}+00$ \\
\hline Two & AI & $\begin{array}{l}1.17 E+01 \\
1.54 E+02 \\
\text { Subtota } 1 \\
1.49 E+03 \\
\text { Tota } 7\end{array}$ & $\begin{array}{r}-1.48 \mathrm{E}-01 \\
9.23 \mathrm{E}-02 \\
-2.77 \mathrm{E}-02 \\
-2.61 \mathrm{E}-01 \\
-1.06 \mathrm{E}-01\end{array}$ & $\begin{array}{l}3.16 \mathrm{E}-02 \\
1.47 \mathrm{E}-01 \\
1.62 \mathrm{E}-01 \\
1.56 \mathrm{E}-01 \\
1.90 \mathrm{E}-01\end{array}$ & $\begin{array}{l}3.71 \mathrm{E}-02 \\
1.35 \mathrm{E}-01 \\
8.84 \mathrm{E}-02 \\
2.11 \mathrm{E}-01 \\
1.27 \mathrm{E}-01\end{array}$ & $5.11 \mathrm{E}-01$ & $5.03 E-01$ \\
\hline Two & AJ & $\begin{array}{l}1.17 E+01 \\
1.54 E+02 \\
\text { Subtotal } \\
1.49 E+03 \\
\text { Total }\end{array}$ & $\begin{array}{l}1.66 \mathrm{E}-01 \\
1.05 \mathrm{E}-01 \\
1.36 \mathrm{E}-01 \\
8.58 \mathrm{E}-02 \\
1.19 \mathrm{E}-01\end{array}$ & $\begin{array}{l}5.58 \mathrm{E}-02 \\
1.13 \mathrm{E}-02 \\
4.90 \mathrm{E}-02 \\
1.16 \mathrm{E}-02 \\
4.64 \mathrm{E}-02\end{array}$ & $\begin{array}{l}4.79 \mathrm{E}-02 \\
1.02 \mathrm{E}-02 \\
3.10 \mathrm{E}-02 \\
1.07 \mathrm{E}-02 \\
2.50 \mathrm{E}-02\end{array}$ & $5.76 \mathrm{E}-01$ & $3.87 \mathrm{E}-02$ \\
\hline
\end{tabular}


TABLE F.1. (Contd)

\begin{tabular}{|c|c|c|c|c|c|c|c|}
\hline \multirow{2}{*}{ Round } & \multirow{2}{*}{ Lab } & \multirow{2}{*}{${ }_{n C}^{A} C_{j}{ }^{\prime}{ }_{L}$} & \multirow{2}{*}{$\mathrm{B}_{r}$} & \multirow{2}{*}{$S_{B}$} & \multirow{2}{*}{$\mathrm{S}_{\mathrm{A}}$} & \multicolumn{2}{|c|}{ MDA, nCi/L } \\
\hline & & & & & & & MDA(2) \\
\hline Two & AL & $\begin{array}{l}1.17 E+01 \\
1.54 E+02 \\
\text { Subtota } 1 \\
1.49 E+03 \\
\text { Tota } 1\end{array}$ & $\begin{array}{l}2.77 \mathrm{E}-01 \\
1.34 \mathrm{E}-01 \\
2.05 \mathrm{E}-01 \\
1.10 \mathrm{E}-01 \\
1.73 \mathrm{E}-01\end{array}$ & $\begin{array}{l}1.47 \mathrm{E}-01 \\
9.93 \mathrm{E}-03 \\
1.22 \mathrm{E}-01 \\
3.98 \mathrm{E}-02 \\
1.09 \mathrm{E}-01\end{array}$ & $\begin{array}{l}1.15 \mathrm{E}-01 \\
8.76 \mathrm{E}-03 \\
7.32 \mathrm{E}-02 \\
3.59 \mathrm{E}-02 \\
6.06 \mathrm{E}-02\end{array}$ & $8.92 E+00$ & $8.59 E+00$ \\
\hline Two & AM & $\begin{array}{l}1.17 E+01 \\
1.54 E+02 \\
\text { Subtota } 1 \\
1.49 E+03 \\
\text { Total }\end{array}$ & $\begin{array}{l}1.55 \mathrm{E}-01 \\
1.44 \mathrm{E}-01 \\
1.49 \mathrm{E}-01 \\
1.24 \mathrm{E}-01 \\
1.41 \mathrm{E}-01\end{array}$ & $\begin{array}{l}\text { 8.35E-02 } \\
6.50 \mathrm{E}-03 \\
5.33 \mathrm{E}-02 \\
1.02 \mathrm{E}-02 \\
4.43 \mathrm{E}-02\end{array}$ & $\begin{array}{l}7.23 \mathrm{E}-02 \\
5.68 \mathrm{E}-03 \\
4.59 \mathrm{E}-02 \\
9.11 \mathrm{E}-03 \\
3.66 \mathrm{E}-02\end{array}$ & $3.63 E+00$ & $3.53 E+00$ \\
\hline Two & AN & $\begin{array}{l}1.17 E+01 \\
1.54 E+02 \\
\text { Subtotal } 1 \\
1.49 E+03 \\
\text { Tota } 1\end{array}$ & $\begin{array}{l}8.65 \mathrm{E}-02 \\
2.38 \mathrm{E}-02 \\
5.52 \mathrm{E}-02 \\
5.14 \mathrm{E}-03 \\
3.85 \mathrm{E}-02\end{array}$ & $\begin{array}{l}2.78 \mathrm{E}-02 \\
1.89 \mathrm{E}-02 \\
4.04 \mathrm{E}-02 \\
1.91 \mathrm{E}-02 \\
4.17 \mathrm{E}-02\end{array}$ & $\begin{array}{l}2.56 \mathrm{E}-02 \\
1.84 \mathrm{E}-02 \\
2.00 \mathrm{E}-02 \\
1.91 \mathrm{E}-02 \\
1.84 \mathrm{E}-02\end{array}$ & $4.07 \mathrm{E}-01$ & $3.61 \mathrm{E}-01$ \\
\hline Two & $\mathrm{AQ}$ & $\begin{array}{l}1.17 E+01 \\
1.54 E+02 \\
\text { Subtota } 1 \\
1.49 E+03 \\
\text { Total }\end{array}$ & $\begin{array}{l}4.40 \mathrm{E}-02 \\
5.55 \mathrm{E}-02 \\
4.97 \mathrm{E}-02 \\
4.56 \mathrm{E}-02 \\
4.83 \mathrm{E}-02\end{array}$ & $\begin{array}{l}6.50 \mathrm{E}-02 \\
3.81 \mathrm{E}-02 \\
4.81 \mathrm{E}-02 \\
6.70 \mathrm{E}-03 \\
3.82 \mathrm{E}-02\end{array}$ & $\begin{array}{l}6.23 \mathrm{E}-02 \\
3.61 \mathrm{E}-02 \\
4.55 \mathrm{E}-02 \\
6.41 \mathrm{E}-03 \\
3.61 \mathrm{E}-02\end{array}$ & $2.40 E+00$ & $2.17 \mathrm{E}+00$ \\
\hline Two & AU & $\begin{array}{l}1.17 E+01 \\
1.54 E+02 \\
\text { Subtotal } \\
1.49 E+03 \\
\text { Total }\end{array}$ & $\begin{array}{l}2.77 \mathrm{E}-01 \\
6.20 \mathrm{E}-02 \\
1.69 \mathrm{E}-01 \\
2.77 \mathrm{E}-02 \\
1.22 \mathrm{E}-01\end{array}$ & $\begin{array}{l}0.00 \mathrm{E}+00 \\
3.75 \mathrm{E}-02 \\
1.20 \mathrm{E}-01 \\
3.87 \mathrm{E}-02 \\
1.20 \mathrm{E}-01\end{array}$ & $\begin{array}{l}0.00 \mathrm{E}+00 \\
3.53 \mathrm{E}-02 \\
2.24 \mathrm{E}-02 \\
3.77 \mathrm{E}-02 \\
2.58 \mathrm{E}-02\end{array}$ & $3.36 \mathrm{E}+00$ & $3.25 E+00$ \\
\hline Two & AV & $\begin{array}{l}1.17 E+01 \\
1.54 E+02 \\
\text { Subtota } 1 \\
1.49 E+03 \\
\text { Total }\end{array}$ & $\begin{array}{l}1.38 \mathrm{E}-01 \\
3.94 \mathrm{E}-02 \\
8.85 \mathrm{E}-02 \\
3.82 \mathrm{E}-02 \\
7.17 \mathrm{E}-02\end{array}$ & $\begin{array}{l}4.37 \mathrm{E}-02 \\
2.94 \mathrm{E}-02 \\
6.32 \mathrm{E}-02 \\
2.32 \mathrm{E}-02 \\
5.72 \mathrm{E}-02\end{array}$ & $\begin{array}{l}3.84 \mathrm{E}-02 \\
2.83 \mathrm{E}-02 \\
3.02 \mathrm{E}-02 \\
2.24 \mathrm{E}-02 \\
2.63 \mathrm{E}-02\end{array}$ & $6.11 E+00$ & $5.35 \mathrm{E}+00$ \\
\hline Two & $B A$ & $\begin{array}{l}1.17 E+01 \\
1.54 E+02 \\
\text { Subtota } 1 \\
1.49 E+03 \\
\text { Tota } 1\end{array}$ & $\begin{array}{l}1.27 \mathrm{E}+00 \\
3.00 \mathrm{E}-01 \\
7.85 \mathrm{E}-01 \\
1.04 \mathrm{E}-01 \\
5.58 \mathrm{E}-01\end{array}$ & $\begin{array}{l}4.28 \mathrm{E}-01 \\
1.13 \mathrm{E}-01 \\
6.00 \mathrm{E}-01 \\
3.17 \mathrm{E}-02 \\
5.84 \mathrm{E}-01\end{array}$ & $\begin{array}{l}1.89 \mathrm{E}-01 \\
8.66 \mathrm{E}-02 \\
1.31 \mathrm{E}-01 \\
2.87 \mathrm{E}-02 \\
1.05 \mathrm{E}-01\end{array}$ & $3.58 E+00$ & $2.68 \mathrm{E}+00$ \\
\hline
\end{tabular}


TABLE F.1. (Contd)

\begin{tabular}{|c|c|c|c|c|c|c|c|}
\hline \multirow[b]{2}{*}{ Round } & \multirow[b]{2}{*}{$\underline{\text { Lab }}$} & \multirow{2}{*}{$\begin{array}{c}\mathrm{A}_{\mathrm{ai}}, \\
\mathrm{nCi} / \mathrm{L}\end{array}$} & \multirow[b]{2}{*}{${ }^{B}{ }_{r}$} & \multirow[b]{2}{*}{$\mathrm{S}_{\mathrm{B}}$} & \multirow[b]{2}{*}{$\mathrm{S}_{\mathrm{A}}$} & \multicolumn{2}{|c|}{$\mathrm{MDA}, \mathrm{nC} \mathrm{i} / \mathrm{L}$} \\
\hline & & & & & & $\operatorname{MDA}(1)$ & $\operatorname{MDA}(2)$ \\
\hline Two & $\mathrm{BB}$ & $\begin{array}{l}1.17 \mathrm{E}+01 \\
1.54 \mathrm{E}+02 \\
\text { Subtota } 1 \\
1.49 \mathrm{E}+03 \\
\text { Total }\end{array}$ & $\begin{array}{l}5.87 \mathrm{E}-01 \\
1.92 \mathrm{E}-01 \\
3.89 \mathrm{E}-01 \\
9.98 \mathrm{E}-02 \\
2.93 \mathrm{E}-01\end{array}$ & $\begin{array}{l}1.76 \mathrm{E}-01 \\
1.17 \mathrm{E}-02 \\
2.43 \mathrm{E}-01 \\
1.62 \mathrm{E}-02 \\
2.41 \mathrm{E}-01\end{array}$ & $\begin{array}{l}1.11 \mathrm{E}-01 \\
9.83 \mathrm{E}-03 \\
7.05 \mathrm{E}-02 \\
1.47 \mathrm{E}-02 \\
5.63 \mathrm{E}-02\end{array}$ & $\mathrm{I} / \mathrm{D}$ & $5.25 E+00$ \\
\hline Two & $\mathrm{BC}$ & $\begin{array}{l}1.17 \mathrm{E}+01 \\
1.54 \mathrm{E}+02 \\
\text { Subtota } 1 \\
1.49 \mathrm{E}+03 \\
\text { Total }\end{array}$ & $\begin{array}{l}5.32 \mathrm{E}-01 \\
1.38 \mathrm{E}-01 \\
3.35 \mathrm{E}-01 \\
1.19 \mathrm{E}-01 \\
2.63 \mathrm{E}-01\end{array}$ & $\begin{array}{l}1.33 E+00 \\
0.00 E+00 \\
8.66 E-01 \\
0.00 E+00 \\
6.93 E-01\end{array}$ & $\begin{array}{l}8.66 \mathrm{E}-01 \\
0.00 \mathrm{E}+00 \\
5.48 \mathrm{E}-01 \\
0.00 \mathrm{E}+00 \\
4.33 \mathrm{E}-01\end{array}$ & $8.10 E+01$ & $7.25 \mathrm{E}+01$ \\
\hline Two & $B D$ & $\begin{array}{l}1.17 E+01 \\
1.54 E+02 \\
\text { Subtota } 1 \\
1.49 E+03 \\
\text { Total }\end{array}$ & $\begin{array}{l}6.94 \mathrm{E}-01 \\
6.20 \mathrm{E}-02 \\
3.78 \mathrm{E}-01 \\
4.56 \mathrm{E}-02 \\
2.67 \mathrm{E}-01\end{array}$ & $\begin{array}{l}1.09 \mathrm{E}-01 \\
9.93 \mathrm{E}-03 \\
3.53 \mathrm{E}-01 \\
1.16 \mathrm{E}-02 \\
3.25 \mathrm{E}-01\end{array}$ & $\begin{array}{l}6.42 \mathrm{E}-02 \\
9.35 \mathrm{E}-03 \\
4.10 \mathrm{E}-02 \\
1.11 \mathrm{E}-02 \\
3.29 \mathrm{E}-02\end{array}$ & $8.35 E+00$ & $8.04 E+00$ \\
\hline Two & $\mathrm{BE}$ & $\begin{array}{l}1.17 E+01 \\
1.54 E+02 \\
\text { Subtota T } \\
1.49 E+03 \\
\text { Tota } 1\end{array}$ & $\begin{array}{r}1.84 \mathrm{E}-02 \\
-3.03 \mathrm{E}-03 \\
7.70 \mathrm{E}-03 \\
-1.34 \mathrm{E}-03 \\
4.69 \mathrm{E}-03\end{array}$ & $\begin{array}{l}4.69 \mathrm{E}-02 \\
9.93 \mathrm{E}-03 \\
3.25 \mathrm{E}-02 \\
6.70 \mathrm{E}-03 \\
2.63 \mathrm{E}-02\end{array}$ & $\begin{array}{l}4.60 E-02 \\
9.96 E-03 \\
2.98 E-02 \\
6.71 E-03 \\
2.38 E-02\end{array}$ & $1.39 \mathrm{E}+00$ & $1.25 \mathrm{E}+00$ \\
\hline Two & $E$ & $\begin{array}{l}1.17 \mathrm{E}+01 \\
1.54 \mathrm{E}+02 \\
\text { Subtota } 1 \\
1.49 \mathrm{E}+03 \\
\text { Total }\end{array}$ & $\begin{array}{l}4.88 \mathrm{E}-01 \\
2.47 \mathrm{E}-01 \\
3.68 \mathrm{E}-01 \\
1.97 \mathrm{E}-01 \\
3.11 \mathrm{E}-01\end{array}$ & $\begin{array}{l}1.25 \mathrm{E}-01 \\
4.98 \mathrm{E}-02 \\
1.57 \mathrm{E}-01 \\
1.38 \mathrm{E}-02 \\
1.51 \mathrm{E}-01\end{array}$ & $\begin{array}{l}8.42 \mathrm{E}-02 \\
3.99 \mathrm{E}-02 \\
5.89 \mathrm{E}-02 \\
1.15 \mathrm{E}-02 \\
4.70 \mathrm{E}-02\end{array}$ & $8.83 E+00$ & $8.74 E+00$ \\
\hline Two & G & $\begin{array}{l}1.17 \mathrm{E}+01 \\
1.54 \mathrm{E}+02 \\
\text { Subtota } 1 \\
1.49 \mathrm{E}+03 \\
\text { Tota 1 }\end{array}$ & $\begin{array}{l}1.01 \mathrm{E}-01 \\
8.21 \mathrm{E}-02 \\
9.14 \mathrm{E}-02 \\
1.22 \mathrm{E}-01 \\
1.01 \mathrm{E}-01\end{array}$ & $\begin{array}{l}5.81 \mathrm{E}-02 \\
2.86 \mathrm{E}-02 \\
4.22 \mathrm{E}-02 \\
2.49 \mathrm{E}-02 \\
3.86 \mathrm{E}-02\end{array}$ & $\begin{array}{l}5.28 \mathrm{E}-02 \\
2.64 \mathrm{E}-02 \\
3.73 \mathrm{E}-02 \\
2.22 \mathrm{E}-02 \\
3.15 \mathrm{E}-02\end{array}$ & $1.54 \mathrm{E}+00$ & $1.52 \mathrm{E}+00$ \\
\hline Two & H & $\begin{array}{l}1.17 \mathrm{E}+01 \\
1.54 \mathrm{E}+02 \\
\text { Subtota } 1 \\
1.49 \mathrm{E}+03 \\
\text { Total }\end{array}$ & $\begin{array}{l}2.41 \mathrm{E}-02 \\
2.30 \mathrm{E}-02 \\
2.35 \mathrm{E}-02 \\
3.44 \mathrm{E}-02 \\
2.72 \mathrm{E}-02\end{array}$ & $\begin{array}{l}1.77 \mathrm{E}-02 \\
9.93 \mathrm{E}-03 \\
1.29 \mathrm{E}-02 \\
1.02 \mathrm{E}-02 \\
1.26 \mathrm{E}-02\end{array}$ & $\begin{array}{l}1.73 \mathrm{E}-02 \\
9.71 \mathrm{E}-03 \\
1.25 \mathrm{E}-02 \\
9.90 \mathrm{E}-03 \\
1.11 \mathrm{E}-02\end{array}$ & $3.89 E-02$ & $2.68 \mathrm{E}-02$ \\
\hline
\end{tabular}


TABLE F.1. (Contd)

\begin{tabular}{|c|c|c|c|c|c|c|c|}
\hline \multirow[b]{2}{*}{ Round } & \multirow[b]{2}{*}{$\underline{L a b}$} & \multirow{2}{*}{$\begin{array}{c}\mathrm{A}_{\mathrm{ai}}, \\
\mathrm{nCi} / \mathrm{L}\end{array}$} & \multirow[b]{2}{*}{$B_{r}$} & \multirow[b]{2}{*}{$S_{B}$} & \multirow[b]{2}{*}{$S_{A}$} & \multicolumn{2}{|c|}{$\mathrm{MDA}, \mathrm{nCi} / \mathrm{L}$} \\
\hline & & & & & & $\operatorname{MDA}(1)$ & $\operatorname{MDA}(2)$ \\
\hline Two & J & $\begin{array}{l}1.17 E+01 \\
1.54 E+02 \\
\text { Subtota } 1 \\
1.49 E+03 \\
\text { Total }\end{array}$ & $\begin{array}{l}1.91 \mathrm{E}-01 \\
1.49 \mathrm{E}-01 \\
1.70 \mathrm{E}-01 \\
1.17 \mathrm{E}-01 \\
1.52 \mathrm{E}-01\end{array}$ & $\begin{array}{l}8.51 \mathrm{E}-02 \\
3.75 \mathrm{E}-02 \\
6.33 \mathrm{E}-02 \\
3.87 \mathrm{E}-03 \\
5.67 \mathrm{E}-02\end{array}$ & $\begin{array}{l}7.14 \mathrm{E}-02 \\
3.27 \mathrm{E}-02 \\
4.97 \mathrm{E}-02 \\
3.46 \mathrm{E}-03 \\
3.93 \mathrm{E}-02\end{array}$ & $7.51 E+00$ & $5.17 \mathrm{E}+00$ \\
\hline Two & K & $\begin{array}{l}1.17 \mathrm{E}+01 \\
1.54 \mathrm{E}+02 \\
\text { Subtota } 1 \\
1.49 \mathrm{E}+03 \\
\text { Tota } 1\end{array}$ & $\begin{array}{r}2.48 \mathrm{E}-01 \\
-2.28 \mathrm{E}-02 \\
1.13 \mathrm{E}-01 \\
1.69 \mathrm{E}-01 \\
1.32 \mathrm{E}-01\end{array}$ & $\begin{array}{l}4.91 \mathrm{E}-02 \\
4.94 \mathrm{E}-02 \\
1.55 \mathrm{E}-01 \\
1.31 \mathrm{E}-02 \\
1.26 \mathrm{E}-01\end{array}$ & $\begin{array}{l}3.94 \mathrm{E}-02 \\
5.06 \mathrm{E}-02 \\
4.05 \mathrm{E}-02 \\
1.12 \mathrm{E}-02 \\
3.25 \mathrm{E}-02\end{array}$ & $2.01 E+00$ & $6.52 \mathrm{E}-01$ \\
\hline Two & L & $\begin{array}{l}1.17 \mathrm{E}+01 \\
1.54 \mathrm{E}+02 \\
\text { Subtota } 1 \\
1.49 \mathrm{E}+03 \\
\text { Total }\end{array}$ & $\begin{array}{l}2.89 \mathrm{E}-02 \\
8.52 \mathrm{E}-02 \\
5.70 \mathrm{E}-02 \\
3.22 \mathrm{E}-02 \\
4.88 \mathrm{E}-02\end{array}$ & $\begin{array}{l}1.45 \mathrm{E}-02 \\
1.14 \mathrm{E}-02 \\
3.29 \mathrm{E}-02 \\
5.97 \mathrm{E}-03 \\
2.90 \mathrm{E}-02\end{array}$ & $\begin{array}{l}1.41 \mathrm{E}-02 \\
1.05 \mathrm{E}-02 \\
1.11 \mathrm{E}-02 \\
5.79 \mathrm{E}-03 \\
9.25 \mathrm{E}-03\end{array}$ & $3.09 E-01$ & $2.84 \mathrm{E}-01$ \\
\hline Two & M & $\begin{array}{l}1.17 \mathrm{E}+01 \\
1.54 \mathrm{E}+02 \\
\text { Subtota } 1 \\
1.49 \mathrm{E}+03 \\
\text { Tota } 7\end{array}$ & $\begin{array}{r}-7.09 \mathrm{E}-03 \\
6.57 \mathrm{E}-02 \\
2.93 \mathrm{E}-02 \\
6.75 \mathrm{E}-02 \\
4.20 \mathrm{E}-02\end{array}$ & $\begin{array}{l}2.60 \mathrm{E}-02 \\
1.72 \mathrm{E}-03 \\
4.31 \mathrm{E}-02 \\
8.75 \mathrm{E}-03 \\
3.93 \mathrm{E}-02\end{array}$ & $\begin{array}{l}2.62 \mathrm{E}-02 \\
1.61 \mathrm{E}-03 \\
1.66 \mathrm{E}-02 \\
8.19 \mathrm{E}-03 \\
1.37 \mathrm{E}-02\end{array}$ & $3.72 E+00$ & $3.53 \mathrm{E}+00$ \\
\hline Two & $\mathrm{N}$ & $\begin{array}{l}1.17 \mathrm{E}+01 \\
1.54 \mathrm{E}+02 \\
\text { Subtota } 1 \\
1.49 \mathrm{E}+03 \\
\text { Tota } 1\end{array}$ & $\begin{array}{r}-2.91 \mathrm{E}-01 \\
4.68 \mathrm{E}-02 \\
-1.22 \mathrm{E}-01 \\
1.04 \mathrm{E}-01 \\
-4.68 \mathrm{E}-02\end{array}$ & $\begin{array}{l}1.30 \mathrm{E}-01 \\
3.38 \mathrm{E}-02 \\
2.03 \mathrm{E}-01 \\
3.87 \mathrm{E}-03 \\
1.97 \mathrm{E}-01\end{array}$ & $\begin{array}{l}1.83 \mathrm{E}-01 \\
3.23 \mathrm{E}-02 \\
1.18 \mathrm{E}-01 \\
3.51 \mathrm{E}-03 \\
9.31 \mathrm{E}-02\end{array}$ & $I / D$ & $0.00 \mathrm{E}+00$ \\
\hline Two & 0 & $\begin{array}{l}1.17 E+01 \\
1.54 E+02 \\
\text { Subtota } 1 \\
1.49 E+03 \\
\text { Tota } 1\end{array}$ & $\begin{array}{l}3.56 \mathrm{E}-01 \\
1.58 \mathrm{E}-01 \\
2.57 \mathrm{E}-01 \\
1.33 \mathrm{E}-01 \\
2.16 \mathrm{E}-01\end{array}$ & $\begin{array}{l}5.13 \mathrm{E}-02 \\
1.08 \mathrm{E}-02 \\
1.13 \mathrm{E}-01 \\
8.91 \mathrm{E}-03 \\
1.09 \mathrm{E}-01\end{array}$ & $\begin{array}{l}3.78 \mathrm{E}-02 \\
9.35 \mathrm{E}-03 \\
2.46 \mathrm{E}-02 \\
7.87 \mathrm{E}-03 \\
1.99 \mathrm{E}-02\end{array}$ & $4.87 E+00$ & $4.90 \mathrm{E}+00$ \\
\hline Two & $S$ & $\begin{array}{l}1.17 \mathrm{E}+01 \\
1.54 \mathrm{E}+02 \\
\text { Subtota } 1 \\
1.49 \mathrm{E}+03 \\
\text { Tota } 1\end{array}$ & $\begin{array}{r}3.83 \mathrm{E}-02 \\
-6.29 \mathrm{E}-03 \\
1.60 \mathrm{E}-02 \\
-8.04 \mathrm{E}-03 \\
7.99 \mathrm{E}-03\end{array}$ & $\begin{array}{l}7.30 \mathrm{E}-02 \\
3.48 \mathrm{E}-02 \\
5.67 \mathrm{E}-02 \\
2.01 \mathrm{E}-02 \\
4.75 \mathrm{E}-02\end{array}$ & $\begin{array}{l}7.03 \mathrm{E}-02 \\
3.50 \mathrm{E}-02 \\
4.97 \mathrm{E}-02 \\
2.03 \mathrm{E}-02 \\
4.05 \mathrm{E}-02\end{array}$ & $4.61 E+00$ & $4.57 \mathrm{E}+00$ \\
\hline
\end{tabular}


TABLE F.1. (Contd)

\begin{tabular}{|c|c|c|c|c|c|c|c|}
\hline \multirow[b]{2}{*}{ Round } & \multirow[b]{2}{*}{$\underline{L a b}$} & \multirow{2}{*}{$\begin{array}{c}A_{a i}, \\
n C i / L\end{array}$} & \multirow[b]{2}{*}{${ }^{B} r$} & \multirow[b]{2}{*}{$S_{B}$} & \multirow[b]{2}{*}{$S_{A}$} & \multicolumn{2}{|c|}{ MDA, nCi/L } \\
\hline & & & & & & $\operatorname{MDA}(1)$ & $\operatorname{MDA}(2)$ \\
\hline Two & V & $\begin{array}{l}1.17 E+01 \\
1.54 E+02 \\
\text { Subtota } 1 \\
1.49 E+03 \\
\text { Total }\end{array}$ & $\begin{array}{l}-2.64 \mathrm{E}-01 \\
-1.28 \mathrm{E}-02 \\
-1.38 \mathrm{E}-01 \\
-2.62 \mathrm{E}-02 \\
-1.01 \mathrm{E}-01\end{array}$ & $\begin{array}{l}3.73 \mathrm{E}-02 \\
9.29 \mathrm{E}-02 \\
1.51 \mathrm{E}-01 \\
6.34 \mathrm{E}-02 \\
1.36 \mathrm{E}-01\end{array}$ & $\begin{array}{l}5.07 \mathrm{E}-02 \\
9.41 \mathrm{E}-02 \\
6.76 \mathrm{E}-02 \\
6.51 \mathrm{E}-02 \\
6.26 \mathrm{E}-02\end{array}$ & $4.59 E+00$ & $3.42 E+00$ \\
\hline
\end{tabular}


TABLE F.2. ${ }^{89} \mathrm{Sr}$ Relative Bias and Precision, and MDA (AMDA $=10 \mathrm{pCi} / \mathrm{L}$ )

\begin{tabular}{|c|c|c|c|c|c|c|c|}
\hline \multirow[b]{2}{*}{ Round } & \multirow[b]{2}{*}{$\underline{\text { Lab }}$} & \multirow{2}{*}{$\begin{array}{c}\mathrm{A}_{\mathrm{ai}}, \\
\mathrm{pC} \mathbf{i} / \mathrm{L} \\
\end{array}$} & \multirow[b]{2}{*}{${ }^{B} r$} & \multirow[b]{2}{*}{$S_{B}$} & \multirow[b]{2}{*}{$\mathrm{S}_{\mathrm{A}}$} & \multicolumn{2}{|c|}{ MDA, $\mathrm{pC} i / \mathrm{L}$} \\
\hline & & & & & & $\operatorname{MDA}(1)$ & $\operatorname{MDA}(2)$ \\
\hline Two & $\mathrm{AJ}$ & $\begin{array}{l}3.69 \mathrm{E}+01 \\
1.08 \mathrm{E}+02 \\
\text { Total }\end{array}$ & $\begin{array}{l}-8.56 \mathrm{E}-01 \\
-1.19 \mathrm{E}+00 \\
-1.02 \mathrm{E}+00\end{array}$ & $\begin{array}{l}1.58 E-01 \\
6.28 E-01 \\
4.49 E-01\end{array}$ & $\begin{array}{l}1.10 E+00 \\
3.28 E+00 \\
2.19 E+00\end{array}$ & $4.88 E+00$ & $4.85 E+01$ \\
\hline Two & AM & $\begin{array}{l}3.69 \mathrm{E}+01 \\
1.08 \mathrm{E}+02 \\
\text { Tota } 1\end{array}$ & $\begin{array}{r}1.56 \mathrm{E}-01 \\
-7.87 \mathrm{E}-02 \\
3.85 \mathrm{E}-02\end{array}$ & $\begin{array}{l}4.56 \mathrm{E}-01 \\
3.90 \mathrm{E}-01 \\
4.00 \mathrm{E}-01\end{array}$ & $\begin{array}{l}3.94 \mathrm{E}-01 \\
4.23 \mathrm{E}-01 \\
3.66 \mathrm{E}-01\end{array}$ & $I / D$ & $3.92 E+01$ \\
\hline Two & AN & $\begin{array}{l}3.69 \mathrm{E}+01 \\
1.08 \mathrm{E}+02 \\
\text { Total }\end{array}$ & $\begin{array}{l}-9.46 \mathrm{E}-01 \\
-5.71 \mathrm{E}-01 \\
-7.59 \mathrm{E}-01\end{array}$ & $\begin{array}{l}5.16 \mathrm{E}-01 \\
6.85 \mathrm{E}-02 \\
3.88 \mathrm{E}-01\end{array}$ & $\begin{array}{l}9.54 \mathrm{E}+00 \\
1.60 \mathrm{E}-01 \\
6.04 \mathrm{E}+00\end{array}$ & $I / D$ & $1.60 \mathrm{E}+01$ \\
\hline Two & AP & $\begin{array}{l}3.69 \mathrm{E}+01 \\
1.08 \mathrm{E}+02 \\
\text { Total } 1\end{array}$ & $\begin{array}{l}3.65 \mathrm{E}-01 \\
4.72 \mathrm{E}-01 \\
4.19 \mathrm{E}-01\end{array}$ & $\begin{array}{l}1.48 \mathrm{E}-01 \\
3.90 \mathrm{E}-01 \\
2.70 \mathrm{E}-01\end{array}$ & $\begin{array}{l}1.08 \mathrm{E}-01 \\
2.65 \mathrm{E}-01 \\
1.81 \mathrm{E}-01\end{array}$ & $2.98 \mathrm{E}+00$ & $2.45 E+00$ \\
\hline Two & $E$ & $\begin{array}{l}3.69 \mathrm{E}+01 \\
1.08 \mathrm{E}+02 \\
\text { Total }\end{array}$ & $\begin{array}{l}-3.13 \mathrm{E}-01 \\
-6.31 \mathrm{E}-01 \\
-4.72 \mathrm{E}-01\end{array}$ & $\begin{array}{l}2.03 \mathrm{E}-01 \\
3.69 \mathrm{E}-02 \\
2.18 \mathrm{E}-01\end{array}$ & $\begin{array}{l}2.96 \mathrm{E}-01 \\
1.00 \mathrm{E}-01 \\
1.98 \mathrm{E}-01\end{array}$ & $I / D$ & $5.37 E+00$ \\
\hline Two & G & $\begin{array}{l}3.69 E+01 \\
1.08 E+02 \\
\text { Tota } 1\end{array}$ & $\begin{array}{l}-1.01 \mathrm{E}-01 \\
-1.43 \mathrm{E}-01 \\
-1.22 \mathrm{E}-01\end{array}$ & $\begin{array}{l}4.89 \mathrm{E}-02 \\
4.19 \mathrm{E}-02 \\
4.69 \mathrm{E}-02\end{array}$ & $\begin{array}{l}5.44 \mathrm{E}-02 \\
4.89 \mathrm{E}-02 \\
4.62 \mathrm{E}-02\end{array}$ & $I / D$ & $1.80 \mathrm{E}+01$ \\
\hline
\end{tabular}


TABLE F.3. ${ }^{90} \mathrm{Sr}$ Relative Bias and Precision, and MDA (AMDA $=10 \mathrm{pCi} / \mathrm{L}$ )

\begin{tabular}{|c|c|c|c|c|c|c|c|}
\hline \multirow[b]{2}{*}{ Round } & \multirow[b]{2}{*}{ Lab } & \multirow{2}{*}{$\begin{array}{c}A_{a i}, \\
p C i / L\end{array}$} & \multirow[b]{2}{*}{$\mathrm{B}_{r}$} & \multirow[b]{2}{*}{$S_{B}$} & \multirow[b]{2}{*}{$S_{A}$} & \multicolumn{2}{|c|}{$\mathrm{MDA}, \mathrm{pCi} / \mathrm{L}$} \\
\hline & & & & & & $\operatorname{MDA}(1)$ & $\operatorname{MDA}(2)$ \\
\hline One & B & $\begin{array}{l}1.69 \mathrm{E}+01 \\
1.85 \mathrm{E}+02 \\
\text { Total }\end{array}$ & $\begin{array}{l}-2.35 E-01 \\
-3.32 E-01 \\
-2.83 E-01\end{array}$ & $\begin{array}{l}2.18 \mathrm{E}-01 \\
5.25 \mathrm{E}-02 \\
1.52 \mathrm{E}-01\end{array}$ & $\begin{array}{l}2.85 \mathrm{E}-01 \\
7.85 \mathrm{E}-02 \\
1.87 \mathrm{E}-01\end{array}$ & $6.33 E+00$ & $4.13 E+00$ \\
\hline One & $E$ & $\begin{array}{l}1.69 \mathrm{E}+01 \\
1.85 \mathrm{E}+02 \\
\text { Tota } 1\end{array}$ & $\begin{array}{l}3.16 \mathrm{E}-02 \\
4.99 \mathrm{E}-02 \\
4.07 \mathrm{E}-02\end{array}$ & $\begin{array}{l}2.07 \mathrm{E}-01 \\
3.49 \mathrm{E}-01 \\
2.57 \mathrm{E}-01\end{array}$ & $\begin{array}{l}2.01 \mathrm{E}-01 \\
3.33 \mathrm{E}-01 \\
2.46 \mathrm{E}-01\end{array}$ & $1.86 \mathrm{E}+00$ & $2.89 \mathrm{E}+00$ \\
\hline One & $F$ & $\begin{array}{l}1.69 E+01 \\
1.85 E+02 \\
\text { Total }\end{array}$ & $\begin{array}{l}-7.30 \mathrm{E}-02 \\
-2.29 \mathrm{E}-01 \\
-1.51 \mathrm{E}-01\end{array}$ & $\begin{array}{l}2.07 \mathrm{E}-01 \\
1.79 \mathrm{E}-01 \\
1.93 \mathrm{E}-01\end{array}$ & $\begin{array}{l}2.23 \mathrm{E}-01 \\
2.32 \mathrm{E}-01 \\
2.04 \mathrm{E}-01\end{array}$ & $7.25 \mathrm{E}-01$ & $8.32 E-01$ \\
\hline One & G & $\begin{array}{l}1.69 \mathrm{E}+01 \\
1.85 \mathrm{E}+02 \\
\text { Tota } 1\end{array}$ & $\begin{array}{l}-1.90 \mathrm{E}-01 \\
-7.10 \mathrm{E}-02 \\
-1.31 \mathrm{E}-01\end{array}$ & $\begin{array}{l}1.67 \mathrm{E}-02 \\
5.14 \mathrm{E}-03 \\
6.63 \mathrm{E}-02\end{array}$ & $\begin{array}{l}2.06 \mathrm{E}-02 \\
5.53 \mathrm{E}-03 \\
1.35 \mathrm{E}-02\end{array}$ & $I / D$ & $1.11 E+00$ \\
\hline One & I & $\begin{array}{l}1.69 E+01 \\
1.85 E+02 \\
\text { Tota } 1\end{array}$ & $\begin{array}{l}-2.96 \mathrm{E}-02 \\
-2.36 \mathrm{E}-01 \\
-1.33 \mathrm{E}-01\end{array}$ & $\begin{array}{l}2.82 \mathrm{E}-01 \\
5.78 \mathrm{E}-02 \\
2.14 \mathrm{E}-01\end{array}$ & $\begin{array}{l}2.90 \mathrm{E}-01 \\
7.57 \mathrm{E}-02 \\
1.90 \mathrm{E}-01\end{array}$ & $1.29 \mathrm{E}+01$ & $1.70 \mathrm{E}+01$ \\
\hline Two & AI & $\begin{array}{l}4.57 E+01 \\
1.24 E+02 \\
\text { Tota } 1\end{array}$ & $\begin{array}{l}-2.95 \mathrm{E}-02 \\
-1.42 \mathrm{E}-02 \\
-2.19 \mathrm{E}-02\end{array}$ & $\begin{array}{l}7.04 \mathrm{E}-02 \\
6.51 \mathrm{E}-02 \\
6.12 \mathrm{E}-02\end{array}$ & $\begin{array}{l}7.25 \mathrm{E}-02 \\
6.61 \mathrm{E}-02 \\
6.20 \mathrm{E}-02\end{array}$ & $I / D$ & $4.09 E+00$ \\
\hline Two & AJ & $\begin{array}{l}4.57 E+01 \\
1.24 E+02 \\
\text { Tota } 7\end{array}$ & $\begin{array}{l}-3.21 \mathrm{E}-03 \\
-2.50 \mathrm{E}-02 \\
-1.41 \mathrm{E}-02\end{array}$ & $\begin{array}{l}8.46 \mathrm{E}-02 \\
2.03 \mathrm{E}-01 \\
1.40 \mathrm{E}-01\end{array}$ & $\begin{array}{l}8.48 \mathrm{E}-02 \\
2.09 \mathrm{E}-01 \\
1.42 \mathrm{E}-01\end{array}$ & $4.88 E+00$ & $1.29 \mathrm{E}+01$ \\
\hline Two & AM & $\begin{array}{l}4.57 E+01 \\
1.24 E+02 \\
\text { Tota } 1\end{array}$ & $\begin{array}{l}-2.19 \mathrm{E}-01 \\
-2.37 \mathrm{E}-01 \\
-2.28 \mathrm{E}-01\end{array}$ & $\begin{array}{l}8.29 \mathrm{E}-02 \\
1.02 \mathrm{E}-01 \\
8.39 \mathrm{E}-02\end{array}$ & $\begin{array}{l}1.06 \mathrm{E}-01 \\
1.34 \mathrm{E}-01 \\
1.08 \mathrm{E}-01\end{array}$ & $2.95 \mathrm{E}+00$ & $8.44 E+00$ \\
\hline Two & AN & $\begin{array}{l}4.57 E+01 \\
1.24 E+02 \\
\text { Tota } 1\end{array}$ & $\begin{array}{l}7.19 \mathrm{E}-02 \\
4.96 \mathrm{E}-02 \\
6.07 \mathrm{E}-02\end{array}$ & $\begin{array}{l}4.71 \mathrm{E}-02 \\
3.40 \mathrm{E}-02 \\
3.87 \mathrm{E}-02\end{array}$ & $\begin{array}{l}4.40 \mathrm{E}-02 \\
3.24 \mathrm{E}-02 \\
3.45 \mathrm{E}-02\end{array}$ & $I / D$ & 2.30E-01 \\
\hline Two & $A P$ & $\begin{array}{l}4.57 \mathrm{E}+01 \\
1.24 \mathrm{E}+02 \\
\text { Total }\end{array}$ & $\begin{array}{l}-1.26 \mathrm{E}-01 \\
-1.22 \mathrm{E}-01 \\
-1.24 \mathrm{E}-01\end{array}$ & $\begin{array}{l}5.57 \mathrm{E}-02 \\
6.90 \mathrm{E}-02 \\
5.61 \mathrm{E}-02\end{array}$ & $\begin{array}{l}6.37 \mathrm{E}-02 \\
7.86 \mathrm{E}-02 \\
6.40 \mathrm{E}-02\end{array}$ & $4.17 E+00$ & $6.75 E-01$ \\
\hline
\end{tabular}


TABLE F.3. (Contd)

\begin{tabular}{|c|c|c|c|c|c|c|c|}
\hline \multirow[b]{2}{*}{ Round } & \multirow[b]{2}{*}{$\underline{L a b}$} & \multirow{2}{*}{$\begin{array}{c}A_{a j}, \\
p C i / L\end{array}$} & \multirow{2}{*}{$\mathrm{B}_{r}$} & \multirow[b]{2}{*}{$S_{B}$} & \multirow[b]{2}{*}{$\mathrm{S}_{\mathrm{A}}$} & \multicolumn{2}{|c|}{$M D A, P C i / L$} \\
\hline & & & & & & $\mathrm{MDA}(1)$ & $\operatorname{MDA}(2)$ \\
\hline Two & $E$ & $\begin{array}{l}4.57 \mathrm{E}+01 \\
1.24 \mathrm{E}+02 \\
\text { Total }\end{array}$ & $\begin{array}{l}-5.99 E-01 \\
-6.08 E-01 \\
-6.03 E-01\end{array}$ & $\begin{array}{l}3.34 \mathrm{E}-02 \\
4.44 \mathrm{E}-02 \\
3.55 \mathrm{E}-02\end{array}$ & $\begin{array}{l}8.33 \mathrm{E}-02 \\
1.13 \mathrm{E}-01 \\
8.89 \mathrm{E}-02\end{array}$ & $6.15 \mathrm{E}+00$ & $4.65 E+00$ \\
\hline Two & G & $\begin{array}{l}4.57 \mathrm{E}+01 \\
1.24 \mathrm{E}+02 \\
\text { Total }\end{array}$ & $\begin{array}{l}-9.52 \mathrm{E}-02 \\
-1.43 \mathrm{E}-01 \\
-1.19 \mathrm{E}-01\end{array}$ & $\begin{array}{l}4.68 \mathrm{E}-02 \\
8.11 \mathrm{E}-02 \\
6.47 \mathrm{E}-02\end{array}$ & $\begin{array}{l}5.17 \mathrm{E}-02 \\
9.46 \mathrm{E}-02 \\
6.82 \mathrm{E}-02\end{array}$ & $\mathrm{I} / \mathrm{D}$ & $6.72 E+00$ \\
\hline Two & $H$ & $\begin{array}{l}4.57 \mathrm{E}+01 \\
1.24 \mathrm{E}+02 \\
\text { Total }\end{array}$ & $\begin{array}{l}4.13 \mathrm{E}-02 \\
7.25 \mathrm{E}-03 \\
2.43 \mathrm{E}-02\end{array}$ & $\begin{array}{l}1.55 \mathrm{E}-02 \\
4.19 \mathrm{E}-02 \\
3.38 \mathrm{E}-02\end{array}$ & $\begin{array}{l}1.49 \mathrm{E}-02 \\
4.16 \mathrm{E}-02 \\
2.79 \mathrm{E}-02\end{array}$ & $1.26 \mathrm{E}+00$ & $1.34 \mathrm{E}-01$ \\
\hline Two & $\mathrm{s}$ & $\begin{array}{l}4.57 E+01 \\
1.24 E+02 \\
\text { Total }\end{array}$ & $\begin{array}{l}-1.85 E-01 \\
-2.16 E-01 \\
-2.01 E-01\end{array}$ & $\begin{array}{l}6.60 \mathrm{E}-02 \\
6.13 \mathrm{E}-02 \\
5.94 \mathrm{E}-02\end{array}$ & $\begin{array}{l}8.10 \mathrm{E}-02 \\
7.82 \mathrm{E}-02 \\
7.12 \mathrm{E}-02\end{array}$ & $1.71 E+00$ & $2.44 \mathrm{E}+00$ \\
\hline
\end{tabular}


TABLE F.4. ${ }^{238} \mathrm{Pu}$ Relative Bias and Precision, and MDA (AMDA $\left.=0.06 \mathrm{pCi} / \mathrm{L}\right)$

\begin{tabular}{|c|c|c|c|c|c|c|c|}
\hline \multirow[b]{2}{*}{ Round } & \multirow[b]{2}{*}{$\underline{L a b}$} & \multirow{2}{*}{$\begin{array}{c}A_{a i}, \\
\mathrm{pC} i / L\end{array}$} & \multirow[b]{2}{*}{${ }^{B}{ }_{r}$} & \multirow[b]{2}{*}{$S_{B}$} & \multirow[b]{2}{*}{${ }^{S_{A}}$} & \multicolumn{2}{|c|}{$M D A, p C i / L$} \\
\hline & & & & & & $\operatorname{MDA}(1)$ & $\mathrm{MDA}(2)$ \\
\hline One & $M$ & $\begin{array}{l}1.07 E-01 \\
9.28 E-01 \\
\text { Tota } 1\end{array}$ & $\begin{array}{r}5.89 \mathrm{E}-01 \\
-1.13 \mathrm{E}-01 \\
2.38 \mathrm{E}-01\end{array}$ & $\begin{array}{l}6.54 E-01 \\
2.20 E-01 \\
5.82 E-01\end{array}$ & $\begin{array}{l}4.12 \mathrm{E}-01 \\
2.48 \mathrm{E}-01 \\
3.04 \mathrm{E}-01\end{array}$ & $2.69 \mathrm{E}-02$ & $2.68 E-02$ \\
\hline One & $Q$ & $\begin{array}{l}1.07 E-01 \\
9.28 E-01 \\
\text { Total }\end{array}$ & $\begin{array}{r}1.77 E+00 \\
-8.05 E-02 \\
8.46 E-01\end{array}$ & $\begin{array}{l}9.36 \mathrm{E}-01 \\
1.65 \mathrm{E}-02 \\
1.18 \mathrm{E}+00\end{array}$ & $\begin{array}{l}3.38 \mathrm{E}-01 \\
1.79 \mathrm{E}-02 \\
2.14 \mathrm{E}-01\end{array}$ & $4.71 E-01$ & $4.03 E-01$ \\
\hline One & $S$ & $\begin{array}{l}1.07 E-01 \\
9.28 E-01 \\
\text { Total }\end{array}$ & $\begin{array}{l}5.92 \mathrm{E}-02 \\
3.45 \mathrm{E}-02 \\
4.68 \mathrm{E}-02\end{array}$ & $\begin{array}{l}1.08 \mathrm{E}-01 \\
6.47 \mathrm{E}-02 \\
8.07 \mathrm{E}-02\end{array}$ & $\begin{array}{l}1.02 \mathrm{E}-01 \\
6.25 \mathrm{E}-02 \\
7.56 \mathrm{E}-02\end{array}$ & $I / D$ & $0.00 E+00$ \\
\hline One & $T$ & $\begin{array}{l}1.07 E-01 \\
9.28 E-01 \\
\text { Total }\end{array}$ & $\begin{array}{l}-2.21 E-01 \\
-1.67 E-01 \\
-1.94 E-01\end{array}$ & $\begin{array}{l}1.08 \mathrm{E}-01 \\
6.13 \mathrm{E}-02 \\
8.40 \mathrm{E}-02\end{array}$ & $\begin{array}{l}1.39 \mathrm{E}-01 \\
7.35 \mathrm{E}-02 \\
9.92 \mathrm{E}-02\end{array}$ & $1.83 \mathrm{E}-02$ & $1.76 \mathrm{E}-02$ \\
\hline One & V & $\begin{array}{l}1.07 \mathrm{E}-01 \\
9.28 \mathrm{E}-01 \\
\text { Total }\end{array}$ & $\begin{array}{r}5.92 \mathrm{E}-02 \\
-5.17 \mathrm{E}-02 \\
3.73 \mathrm{E}-03\end{array}$ & $\begin{array}{l}3.78 \mathrm{E}-01 \\
4.94 \mathrm{E}-02 \\
2.48 \mathrm{E}-01\end{array}$ & $\begin{array}{l}3.57 \mathrm{E}-01 \\
5.21 \mathrm{E}-02 \\
2.28 \mathrm{E}-01\end{array}$ & $3.22 \mathrm{E}-01$ & $1.23 \mathrm{E}-01$ \\
\hline Two & $A P$ & $\begin{array}{l}1.81 E-01 \\
7.21 E-01 \\
\text { Total }\end{array}$ & $\begin{array}{l}-1.34 \mathrm{E}-01 \\
-6.15 \mathrm{E}-02 \\
-9.80 \mathrm{E}-02\end{array}$ & $\begin{array}{l}1.94 \mathrm{E}-01 \\
4.46 \mathrm{E}-02 \\
1.32 \mathrm{E}-01\end{array}$ & $\begin{array}{l}2.24 \mathrm{E}-01 \\
4.75 \mathrm{E}-02 \\
1.45 \mathrm{E}-01\end{array}$ & $8.37 E-02$ & $8.05 \mathrm{E}-02$ \\
\hline Two & $E$ & $\begin{array}{l}1.90 \mathrm{E}-01 \\
7.42 \mathrm{E}-01 \\
\text { Total }\end{array}$ & $\begin{array}{l}-8.77 \mathrm{E}-02 \\
-2.70 \mathrm{E}-03 \\
-4.52 \mathrm{E}-02\end{array}$ & $\begin{array}{l}8.04 \mathrm{E}-02 \\
6.18 \mathrm{E}-02 \\
7.92 \mathrm{E}-02\end{array}$ & $\begin{array}{l}8.81 \mathrm{E}-02 \\
6.19 \mathrm{E}-02 \\
6.81 \mathrm{E}-02\end{array}$ & $5.04 \mathrm{E}-01$ & $2.64 \mathrm{E}-01$ \\
\hline Two & $H$ & $\begin{array}{l}1.82 E-01 \\
7.21 E-01 \\
\text { Total }\end{array}$ & $\begin{array}{l}-2.31 \mathrm{E}-01 \\
-5.22 \mathrm{E}-02 \\
-1.42 \mathrm{E}-01\end{array}$ & $\begin{array}{l}5.49 \mathrm{E}-02 \\
5.25 \mathrm{E}-02 \\
1.09 \mathrm{E}-01\end{array}$ & $\begin{array}{l}7.14 \mathrm{E}-02 \\
5.54 \mathrm{E}-02 \\
5.72 \mathrm{E}-02\end{array}$ & $6.80 \mathrm{E}-02$ & $2.68 \mathrm{E}-02$ \\
\hline Two & N & $\begin{array}{l}1.90 \mathrm{E}-01 \\
7.42 \mathrm{E}-01 \\
\text { Total }\end{array}$ & $\begin{array}{r}-1.05 E-01 \\
3.32 E-02 \\
-3.60 E-02\end{array}$ & $\begin{array}{l}1.39 \mathrm{E}-01 \\
3.89 \mathrm{E}-02 \\
1.19 \mathrm{E}-01\end{array}$ & $\begin{array}{l}1.56 \mathrm{E}-01 \\
3.77 \mathrm{E}-02 \\
1.01 \mathrm{E}-01\end{array}$ & $4.19 \mathrm{E}-02$ & $2.68 \mathrm{E}-02$ \\
\hline Two & 0 & $\begin{array}{l}1.82 E-01 \\
7.21 E-01 \\
\text { Total }\end{array}$ & $\begin{array}{l}-4.76 \mathrm{E}-02 \\
-1.17 \mathrm{E}-01 \\
-8.23 \mathrm{E}-02\end{array}$ & $\begin{array}{l}3.17 \mathrm{E}-02 \\
9.02 \mathrm{E}-02 \\
7.14 \mathrm{E}-02\end{array}$ & $\begin{array}{l}3.33 E-02 \\
1.02 E-01 \\
6.80 E-02\end{array}$ & $6.48 \mathrm{E}-02$ & $0.00 E+00$ \\
\hline Two & $S$ & $\begin{array}{l}1.90 \mathrm{E}-01 \\
7.42 \mathrm{E}-01 \\
\text { Total }\end{array}$ & $\begin{array}{l}-1.23 E-01 \\
-5.21 E-02 \\
-8.75 E-02\end{array}$ & $\begin{array}{l}3.04 \mathrm{E}-02 \\
4.33 \mathrm{E}-02 \\
5.12 \mathrm{E}-02\end{array}$ & $\begin{array}{l}3.46 E-02 \\
4.57 E-02 \\
3.63 E-02\end{array}$ & $4.24 E-03$ & $1.77 E-03$ \\
\hline
\end{tabular}


TABLE F.5. ${ }^{241} \mathrm{Am}$ Relative Bias and Precision, and MDA (AMDA $=0.06 \mathrm{pCi} / \mathrm{L}$ )

\begin{tabular}{|c|c|c|c|c|c|c|c|}
\hline \multirow[b]{2}{*}{ Round } & \multirow[b]{2}{*}{$\underline{L a b}$} & \multirow{2}{*}{$\begin{array}{r}\mathrm{A}_{\mathrm{a} i}, \\
\mathrm{pC} i / \mathrm{L}\end{array}$} & \multirow[b]{2}{*}{${ }^{B}{ }_{r}$} & \multirow[b]{2}{*}{$\mathrm{S}_{\mathrm{B}}$} & \multirow[b]{2}{*}{$S_{A}$} & \multicolumn{2}{|c|}{ MDA, $\mathrm{pC} i / L$} \\
\hline & & & & & & $\operatorname{MDA}(1)$ & $\operatorname{MDA}(2)$ \\
\hline One & M & $\begin{array}{l}8.90 \mathrm{E}-02 \\
9.10 \mathrm{E}-01 \\
\text { Total }\end{array}$ & $\begin{array}{l}-2.13 \mathrm{E}-01 \\
-1.28 \mathrm{E}-01 \\
-1.71 \mathrm{E}-01\end{array}$ & $\begin{array}{l}1.95 \mathrm{E}-01 \\
1.52 \mathrm{E}-01 \\
1.63 \mathrm{E}-01\end{array}$ & $\begin{array}{l}2.47 \mathrm{E}-01 \\
1.74 \mathrm{E}-01 \\
1.91 \mathrm{E}-01\end{array}$ & 1.24E-01 & $1.17 \mathrm{E}-01$ \\
\hline One & $Q$ & $\begin{array}{l}8.90 \mathrm{E}-02 \\
9.10 \mathrm{E}-01 \\
\text { Total }\end{array}$ & $\begin{array}{r}2.73 E-01 \\
-2.12 E-01 \\
3.05 E-02\end{array}$ & $\begin{array}{l}7.48 E-01 \\
7.06 E-02 \\
5.45 E-01\end{array}$ & $\begin{array}{l}5.87 E-01 \\
8.97 E-02 \\
3.76 E-01\end{array}$ & $I / D$ & $7.10 \mathrm{E}-02$ \\
\hline One & $S$ & $\begin{array}{l}8.90 \mathrm{E}-02 \\
9.10 \mathrm{E}-01 \\
\text { Total }\end{array}$ & $\begin{array}{l}1.24 \mathrm{E}-01 \\
4.40 \mathrm{E}-02 \\
8.38 \mathrm{E}-02\end{array}$ & $\begin{array}{l}3.89 \mathrm{E}-01 \\
1.99 \mathrm{E}-01 \\
2.80 \mathrm{E}-01\end{array}$ & $\begin{array}{l}3.46 \mathrm{E}-01 \\
1.90 \mathrm{E}-01 \\
2.50 \mathrm{E}-01\end{array}$ & $I / D$ & $1.88 \mathrm{E}-01$ \\
\hline One & $\mathrm{T}$ & $\begin{array}{l}8.90 \mathrm{E}-02 \\
9.10 \mathrm{E}-01 \\
\text { Total }\end{array}$ & $\begin{array}{l}-7.75 E-01 \\
-3.30 E-02 \\
-4.04 E-01\end{array}$ & $\begin{array}{l}1.12 \mathrm{E}-01 \\
4.79 \mathrm{E}-02 \\
4.14 \mathrm{E}-01\end{array}$ & $\begin{array}{l}5.00 \mathrm{E}-01 \\
4.95 \mathrm{E}-02 \\
3.18 \mathrm{E}-01\end{array}$ & $3.86 \mathrm{E}-02$ & 1.17E-01 \\
\hline One & V & $\begin{array}{l}8.90 \mathrm{E}-02 \\
9.10 \mathrm{E}-01 \\
\text { Total }\end{array}$ & $\begin{array}{l}-6.37 E-02 \\
-6.59 E-02 \\
-6.48 E-02\end{array}$ & $\begin{array}{l}2.59 \mathrm{E}-01 \\
8.30 \mathrm{E}-02 \\
1.72 \mathrm{E}-01\end{array}$ & $\begin{array}{l}2.77 \mathrm{E}-01 \\
8.88 \mathrm{E}-02 \\
1.84 \mathrm{E}-01\end{array}$ & $I / D$ & $1.34 \mathrm{E}-01$ \\
\hline Two & $E$ & $\begin{array}{l}1.89 E-01 \\
7.52 E-01 \\
\text { Tota } 1\end{array}$ & $\begin{array}{l}5.52 \mathrm{E}-01 \\
9.93 \mathrm{E}-02 \\
3.26 \mathrm{E}-01\end{array}$ & $\begin{array}{l}8.10 \mathrm{E}-01 \\
1.15 \mathrm{E}-01 \\
5.74 \mathrm{E}-01\end{array}$ & $\begin{array}{l}5.22 \mathrm{E}-01 \\
1.04 \mathrm{E}-01 \\
3.37 \mathrm{E}-01\end{array}$ & $1.27 E+00$ & $7.82 E-01$ \\
\hline Two & $H$ & $\begin{array}{l}1.81 E-01 \\
7.30 E-01 \\
\text { Tota } 1\end{array}$ & $\begin{array}{l}-5.40 E-01 \\
-6.07 E-01 \\
-5.73 E-01\end{array}$ & $\begin{array}{l}1.69 \mathrm{E}-01 \\
3.95 \mathrm{E}-02 \\
1.16 \mathrm{E}-01\end{array}$ & $\begin{array}{l}3.67 \mathrm{E}-01 \\
1.01 \mathrm{E}-01 \\
2.40 \mathrm{E}-01\end{array}$ & $1.41 E-01$ & 5. $37 \mathrm{E}-02$ \\
\hline Two & 0 & $\begin{array}{l}1.81 E-01 \\
7.30 E-01 \\
\text { Tota } 1\end{array}$ & $\begin{array}{l}-1.16 \mathrm{E}-01 \\
-2.74 \mathrm{E}-02 \\
-7.17 \mathrm{E}-02\end{array}$ & $\begin{array}{l}5.52 \mathrm{E}-02 \\
4.11 \mathrm{E}-02 \\
6.52 \mathrm{E}-02\end{array}$ & $\begin{array}{l}6.25 \mathrm{E}-02 \\
4.23 \mathrm{E}-02 \\
4.77 \mathrm{E}-02\end{array}$ & $7.98 \mathrm{E}-02$ & $0.00 \mathrm{E}+00$ \\
\hline Two & $S$ & $\begin{array}{l}1.89 E-01 \\
7.52 E-01 \\
\text { Tota } 1\end{array}$ & $\begin{array}{l}-2.95 \mathrm{E}-01 \\
-3.79 \mathrm{E}-01 \\
-3.37 \mathrm{E}-01\end{array}$ & $\begin{array}{l}1.62 \mathrm{E}-01 \\
2.09 \mathrm{E}-01 \\
1.73 \mathrm{E}-01\end{array}$ & $\begin{array}{l}2.29 \mathrm{E}-01 \\
3.36 \mathrm{E}-01 \\
2.57 \mathrm{E}-01\end{array}$ & $8.14 E-03$ & $1.49 \mathrm{E}-03$ \\
\hline
\end{tabular}


TABLE F.6. Natural Uranium Relative Bias and Precision, and MDA $($ AMDA $=5 \mu \mathrm{g} / \mathrm{L})$

\begin{tabular}{|c|c|c|c|c|c|c|c|}
\hline \multirow[b]{2}{*}{ Round } & \multirow[b]{2}{*}{$\underline{L a b}$} & \multirow{2}{*}{$\begin{array}{c}A_{a i}, \\
\mu g / L\end{array}$} & \multirow[b]{2}{*}{${ }^{B} r$} & \multirow[b]{2}{*}{$S_{B}$} & \multirow[b]{2}{*}{$S_{A}$} & \multicolumn{2}{|c|}{$\mathrm{MDA}, \mu \mathrm{g} / \mathrm{L}$} \\
\hline & & & & & & $\operatorname{MDA}(1)$ & $\operatorname{MDA}(2)$ \\
\hline One & c & $\begin{array}{l}7.24 E+00 \\
7.78 E+01 \\
\text { Total }\end{array}$ & $\begin{array}{l}9.34 \mathrm{E}-01 \\
3.28 \mathrm{E}-01 \\
6.31 \mathrm{E}-01\end{array}$ & $\begin{array}{l}2.39 \mathrm{E}-01 \\
1.26 \mathrm{E}-01 \\
3.73 \mathrm{E}-01\end{array}$ & $\begin{array}{l}1.24 \mathrm{E}-01 \\
9.50 \mathrm{E}-02 \\
9.86 \mathrm{E}-02\end{array}$ & $I / D$ & $1.89 E+01$ \\
\hline One & $H$ & $\begin{array}{l}7.24 E+00 \\
7.78 E+01 \\
\text { Total }\end{array}$ & $\begin{array}{l}-3.09 \mathrm{E}-01 \\
-3.06 \mathrm{E}-01 \\
-3.08 \mathrm{E}-01\end{array}$ & $\begin{array}{l}1.38 \mathrm{E}-01 \\
2.23 \mathrm{E}-02 \\
8.85 \mathrm{E}-02\end{array}$ & $\begin{array}{l}2.00 \mathrm{E}-01 \\
3.21 \mathrm{E}-02 \\
1.28 \mathrm{E}-01\end{array}$ & $I / D$ & $0.00 E+00$ \\
\hline One & K & $\begin{array}{l}7.24 E+00 \\
7.78 E+01 \\
\text { Total }\end{array}$ & $\begin{array}{r}1.03 \mathrm{E}+00 \\
-2.31 \mathrm{E}-02 \\
5.01 \mathrm{E}-01\end{array}$ & $\begin{array}{l}7.97 \mathrm{E}-02 \\
1.27 \mathrm{E}-01 \\
5.82 \mathrm{E}-01\end{array}$ & $\begin{array}{l}3.94 \mathrm{E}-02 \\
1.30 \mathrm{E}-01 \\
8.57 \mathrm{E}-02\end{array}$ & $I / D$ & $2.68 \mathrm{E}+00$ \\
\hline One & 0 & $\begin{array}{l}7.24 E+00 \\
7.78 E+01 \\
\text { Total }\end{array}$ & $\begin{array}{l}-1.29 \mathrm{E}-02 \\
-8.40 \mathrm{E}-02 \\
-4.84 \mathrm{E}-02\end{array}$ & $\begin{array}{l}7.10 \mathrm{E}-02 \\
2.40 \mathrm{E}-02 \\
6.13 \mathrm{E}-02\end{array}$ & $\begin{array}{l}7.19 \mathrm{E}-02 \\
2.62 \mathrm{E}-02 \\
4.84 \mathrm{E}-02\end{array}$ & $I / D$ & $1.68 \mathrm{E}-01$ \\
\hline One & Q & $\begin{array}{l}7.24 E+00 \\
7.78 E+01 \\
\text { Total }\end{array}$ & $\begin{array}{r}1.15 E+00 \\
-6.43 E-03 \\
5.70 E-01\end{array}$ & $\begin{array}{l}2.64 \mathrm{E}-01 \\
9.00 \mathrm{E}-02 \\
6.55 \mathrm{E}-01\end{array}$ & $\begin{array}{l}1.23 \mathrm{E}-01 \\
9.06 \mathrm{E}-02 \\
9.67 \mathrm{E}-02\end{array}$ & $I / D$ & $2.37 E+01$ \\
\hline One & $R$ & $\begin{array}{l}7.24 E+00 \\
7.78 E+01 \\
\text { Total }\end{array}$ & $\begin{array}{l}3.44 \mathrm{E}-01 \\
9.04 \mathrm{E}-02 \\
2.17 \mathrm{E}-01\end{array}$ & $\begin{array}{l}5.58 \mathrm{E}-02 \\
8.69 \mathrm{E}-02 \\
1.54 \mathrm{E}-01\end{array}$ & $\begin{array}{l}4.15 \mathrm{E}-02 \\
7.97 \mathrm{E}-02 \\
5.68 \mathrm{E}-02\end{array}$ & $I / D$ & $5.37 E-01$ \\
\hline One & $S$ & $\begin{array}{l}7.78 E+01 \\
7.24 E+00 \\
\text { Total }\end{array}$ & $\begin{array}{l}2.83 \mathrm{E}-02 \\
3.13 \mathrm{E}-02 \\
2.98 \mathrm{E}-02\end{array}$ & $\begin{array}{l}4.39 \mathrm{E}-02 \\
7.75 \mathrm{E}-02 \\
5.64 \mathrm{E}-02\end{array}$ & $\begin{array}{l}4.26 \mathrm{E}-02 \\
7.52 \mathrm{E}-02 \\
5.47 \mathrm{E}-02\end{array}$ & $I / D$ & $6.33 E-01$ \\
\hline Two & $A B$ & $\begin{array}{l}1.67 E+01 \\
5.21 E+01 \\
\text { Total }\end{array}$ & $\begin{array}{r}2.77 \mathrm{E}-01 \\
-3.28 \mathrm{E}-01 \\
-2.52 \mathrm{E}-02\end{array}$ & $\begin{array}{l}3.46 \mathrm{E}-02 \\
1.92 \mathrm{E}-02 \\
3.32 \mathrm{E}-01\end{array}$ & $\begin{array}{l}2.71 \mathrm{E}-02 \\
2.86 \mathrm{E}-02 \\
2.49 \mathrm{E}-02\end{array}$ & $I / D$ & $2.68 \mathrm{E}+00$ \\
\hline Two & $A C$ & $\begin{array}{l}1.67 E+01 \\
5.21 E+01 \\
\text { Total }\end{array}$ & $\begin{array}{r}6.39 \mathrm{E}-02 \\
-3.02 \mathrm{E}-02 \\
1.69 \mathrm{E}-02\end{array}$ & $\begin{array}{l}8.15 \mathrm{E}-02 \\
4.19 \mathrm{E}-02 \\
7.75 \mathrm{E}-02\end{array}$ & $\begin{array}{l}7.66 \mathrm{E}-02 \\
4.32 \mathrm{E}-02 \\
5.56 \mathrm{E}-02\end{array}$ & $I / D$ & $1.04 E+01$ \\
\hline Two & $A D$ & $\begin{array}{l}1.67 E+01 \\
5.21 E+01 \\
\text { Tota } 7\end{array}$ & $\begin{array}{l}-4.45 \mathrm{E}-01 \\
-3.92 \mathrm{E}-01 \\
-4.18 \mathrm{E}-01\end{array}$ & $\begin{array}{l}2.41 \mathrm{E}-01 \\
4.44 \mathrm{E}-02 \\
1.58 \mathrm{E}-01\end{array}$ & $\begin{array}{l}4.35 \mathrm{E}-01 \\
7.29 \mathrm{E}-02 \\
2.79 \mathrm{E}-01\end{array}$ & $I / D$ & $0.00 E+00$ \\
\hline
\end{tabular}


TABLE F.6. (Contd)

\begin{tabular}{|c|c|c|c|c|c|c|c|}
\hline \multirow[b]{2}{*}{ Round } & \multirow[b]{2}{*}{$\underline{L a b}$} & \multirow{2}{*}{$\begin{array}{c}A_{a i}, \\
\mu G / L\end{array}$} & \multirow{2}{*}{$B_{r}$} & \multirow[b]{2}{*}{$S_{B}$} & \multirow[b]{2}{*}{$S_{A}$} & \multicolumn{2}{|c|}{$\mathrm{MDA}, \mu \mathrm{g} / \mathrm{L}$} \\
\hline & & & & & & $\operatorname{MDA}(1)$ & $\operatorname{MDA}(2)$ \\
\hline Two & $A G$ & $\begin{array}{l}1.67 E+01 \\
5.21 E+01 \\
\text { Total }\end{array}$ & $\begin{array}{l}6.57 E-01 \\
2.04 E-01 \\
4.30 E-01\end{array}$ & $\begin{array}{l}6.91 \mathrm{E}-01 \\
1.44 \mathrm{E}-01 \\
5.11 \mathrm{E}-01\end{array}$ & $\begin{array}{l}4.17 \mathrm{E}-01 \\
1.20 \mathrm{E}-01 \\
2.75 \mathrm{E}-01\end{array}$ & $\mathrm{I} / \mathrm{D}$ & $2.39 E+01$ \\
\hline Two & $A H$ & $\begin{array}{l}1.67 \mathrm{E}+01 \\
5.21 \mathrm{E}+01 \\
\text { Total }\end{array}$ & $\begin{array}{l}-1.24 \mathrm{E}-01 \\
-1.43 \mathrm{E}-01 \\
-1.33 \mathrm{E}-01\end{array}$ & $\begin{array}{l}1.73 \mathrm{E}-02 \\
1.06 \mathrm{E}-02 \\
1.65 \mathrm{E}-02\end{array}$ & $\begin{array}{l}1.97 \mathrm{E}-02 \\
1.23 \mathrm{E}-02 \\
1.47 \mathrm{E}-02\end{array}$ & $\mathrm{I} / \mathrm{D}$ & $0.00 E+00$ \\
\hline Two & $A Q$ & $\begin{array}{l}1.67 E+01 \\
5.21 E+01 \\
\text { Total }\end{array}$ & $\begin{array}{l}1.32 \mathrm{E}-01 \\
1.35 \mathrm{E}-01 \\
1.33 \mathrm{E}-01\end{array}$ & $\begin{array}{l}5.57 \mathrm{E}-02 \\
3.89 \mathrm{E}-02 \\
4.30 \mathrm{E}-02\end{array}$ & $\begin{array}{l}4.92 \mathrm{E}-02 \\
3.43 \mathrm{E}-02 \\
3.79 \mathrm{E}-02\end{array}$ & $I / D$ & $8.85 E-01$ \\
\hline Two & $E$ & $\begin{array}{l}1.67 E+01 \\
5.21 E+01 \\
\text { Total }\end{array}$ & $\begin{array}{l}-1.02 \mathrm{E}-01 \\
-1.42 \mathrm{E}-01 \\
-1.22 \mathrm{E}-01\end{array}$ & $\begin{array}{l}5.99 \mathrm{E}-02 \\
2.93 \mathrm{E}-02 \\
4.76 \mathrm{E}-02\end{array}$ & $\begin{array}{l}6.67 \mathrm{E}-02 \\
3.42 \mathrm{E}-02 \\
4.74 \mathrm{E}-02\end{array}$ & $I / D$ & $5.37 E+00$ \\
\hline Two & $H$ & $\begin{array}{l}1.67 \mathrm{E}+01 \\
5.21 \mathrm{E}+01 \\
\text { Total }\end{array}$ & $\begin{array}{l}7.37 \mathrm{E}-01 \\
1.71 \mathrm{E}-01 \\
4.54 \mathrm{E}-01\end{array}$ & $\begin{array}{l}3.74 \mathrm{E}-01 \\
3.84 \mathrm{E}-02 \\
3.90 \mathrm{E}-01\end{array}$ & $\begin{array}{l}2.15 \mathrm{E}-01 \\
3.28 \mathrm{E}-02 \\
1.38 \mathrm{E}-01\end{array}$ & $I / D$ & $2.79 E+01$ \\
\hline Two & k & $\begin{array}{l}1.67 E+01 \\
5.21 E+01 \\
\text { Total }\end{array}$ & $\begin{array}{r}-8.18 \mathrm{E}-02 \\
1.65 \mathrm{E}-01 \\
4.16 \mathrm{E}-02\end{array}$ & $\begin{array}{l}3.46 \mathrm{E}-02 \\
7.76 \mathrm{E}-02 \\
1.46 \mathrm{E}-01\end{array}$ & $\begin{array}{l}3.77 \mathrm{E}-02 \\
6.66 \mathrm{E}-02 \\
4.84 \mathrm{E}-02\end{array}$ & $\mathrm{I} / \mathrm{D}$ & $2.68 \mathrm{E}+00$ \\
\hline Two & 0 & $\begin{array}{l}1.67 E+01 \\
5.21 E+01 \\
\text { Total }\end{array}$ & $\begin{array}{l}-1.08 \mathrm{E}-01 \\
-9.61 \mathrm{E}-02 \\
-1.02 \mathrm{E}-01\end{array}$ & $\begin{array}{l}4.32 \mathrm{E}-02 \\
2.65 \mathrm{E}-02 \\
3.27 \mathrm{E}-02\end{array}$ & $\begin{array}{l}4.84 \mathrm{E}-02 \\
2.93 \mathrm{E}-02 \\
3.58 \mathrm{E}-02\end{array}$ & $\mathrm{I} / \mathrm{D}$ & $0.00 \mathrm{E}+00$ \\
\hline Two & $\mathrm{R}$ & $\begin{array}{l}1.67 E+01 \\
5.21 E+01 \\
\text { Total }\end{array}$ & $\begin{array}{l}-2.14 \mathrm{E}-01 \\
-1.98 \mathrm{E}-03 \\
-1.08 \mathrm{E}-01\end{array}$ & $\begin{array}{l}5.88 \mathrm{E}-02 \\
2.72 \mathrm{E}-02 \\
1.23 \mathrm{E}-01\end{array}$ & $\begin{array}{l}7.47 \mathrm{E}-02 \\
2.72 \mathrm{E}-02 \\
5.03 \mathrm{E}-02\end{array}$ & $I / D$ & $0.00 E+00$ \\
\hline Two & $S$ & $\begin{array}{l}1.67 \mathrm{E}+01 \\
5.21 \mathrm{E}+01 \\
\text { Total }\end{array}$ & $\begin{array}{l}-2.51 \mathrm{E}-01 \\
-2.77 \mathrm{E}-01 \\
-2.64 \mathrm{E}-01\end{array}$ & $\begin{array}{l}1.08 \mathrm{E}-01 \\
2.82 \mathrm{E}-01 \\
1.92 \mathrm{E}-01\end{array}$ & $\begin{array}{l}1.44 \mathrm{E}-01 \\
3.91 \mathrm{E}-01 \\
2.63 \mathrm{E}-01\end{array}$ & $\mathrm{I} / \mathrm{D}$ & $2.68 \mathrm{E}-02$ \\
\hline Two & V & $\begin{array}{l}1.67 \mathrm{E}+01 \\
5.21 \mathrm{E}+01 \\
\text { Total }\end{array}$ & $\begin{array}{r}9.74 \mathrm{E}-02 \\
-2.52 \mathrm{E}-02 \\
3.61 \mathrm{E}-02\end{array}$ & $\begin{array}{l}5.50 \mathrm{E}-02 \\
1.23 \mathrm{E}-01 \\
1.08 \mathrm{E}-01\end{array}$ & $\begin{array}{l}5.01 \mathrm{E}-02 \\
1.26 \mathrm{E}-01 \\
8.58 \mathrm{E}-02\end{array}$ & $\mathrm{I} / \mathrm{D}$ & $7.36 \mathrm{E}-01$ \\
\hline
\end{tabular}




\section{TABLE F.6. (Contd)}

\begin{tabular}{|c|c|c|c|c|c|c|c|}
\hline \multirow[b]{2}{*}{ Round } & \multirow[b]{2}{*}{$\underline{L a b}$} & \multirow{2}{*}{$\begin{array}{c}A_{a i}, \\
\mu g / L\end{array}$} & \multirow[b]{2}{*}{$B_{r}$} & \multirow[b]{2}{*}{$S_{B}$} & \multirow[b]{2}{*}{$\mathrm{S}_{\mathrm{A}}$} & \multicolumn{2}{|c|}{ MDA, $\mu \mathrm{g} / \mathrm{L}$} \\
\hline & & & & & & $\operatorname{MDA}(1)$ & $\operatorname{MDA}(2)$ \\
\hline Two & $x$ & $\begin{array}{l}1.67 E+01 \\
5.21 E+01 \\
\text { Tota } 1\end{array}$ & $\begin{array}{l}1.02 E+00 \\
2.93 E-01 \\
6.55 E-01\end{array}$ & $\begin{array}{l}9.15 \mathrm{E}-02 \\
2.93 \mathrm{E}-02 \\
4.01 \mathrm{E}-01\end{array}$ & $\begin{array}{l}4.54 \mathrm{E}-02 \\
2.27 \mathrm{E}-02 \\
3.21 \mathrm{E}-02\end{array}$ & $I / D$ & $2.68 E+00$ \\
\hline Two & Y & $\begin{array}{l}1.67 E+01 \\
5.21 E+01 \\
\text { Tota } 1\end{array}$ & $\begin{array}{l}9.78 \mathrm{E}-02 \\
1.46 \mathrm{E}-01 \\
1.22 \mathrm{E}-01\end{array}$ & $\begin{array}{l}1.25 \mathrm{E}-01 \\
4.83 \mathrm{E}-02 \\
8.86 \mathrm{E}-02\end{array}$ & $\begin{array}{l}1.14 \mathrm{E}-01 \\
4.22 \mathrm{E}-02 \\
7.66 \mathrm{E}-02\end{array}$ & $I / D$ & $2.68 E+00$ \\
\hline
\end{tabular}


TABLE F.7. ${ }^{60}$ Co Relative Bias and Precision, and MDA (AMDA $=50 \mathrm{pC} \mathrm{i} / \mathrm{L}$ )

\begin{tabular}{|c|c|c|c|c|c|c|c|}
\hline \multirow[b]{2}{*}{ Round } & \multirow[b]{2}{*}{$\underline{L a b}$} & \multirow{2}{*}{$\begin{array}{l}A_{a j}, \\
\mathrm{pCi/L}\end{array}$} & \multirow[b]{2}{*}{${ }^{B} r$} & \multirow[b]{2}{*}{$S_{B}$} & \multirow[b]{2}{*}{$S_{A}$} & \multicolumn{2}{|c|}{$\mathrm{MDA}, \mathrm{pC} i / \mathrm{L}$} \\
\hline & & & & & & $\operatorname{MDA}(1)$ & $\operatorname{MDA}(2)$ \\
\hline Two & $A D$ & $\begin{array}{l}1.96 \mathrm{E}+02 \\
9.83 \mathrm{E}+02 \\
\text { Total }\end{array}$ & $\begin{array}{l}4.51 \mathrm{E}-01 \\
2.00 \mathrm{E}-01 \\
3.26 \mathrm{E}-01\end{array}$ & $\begin{array}{l}3.19 E-01 \\
4.07 E-02 \\
2.45 E-01\end{array}$ & $\begin{array}{l}2.20 \mathrm{E}-01 \\
3.39 \mathrm{E}-02 \\
1.41 \mathrm{E}-01\end{array}$ & $\mathrm{I} / \mathrm{D}$ & $1.35 E+02$ \\
\hline Two & $A E$ & $\begin{array}{l}2.30 \mathrm{E}+02 \\
9.88 \mathrm{E}+02 \\
\text { Tota } 1\end{array}$ & $\begin{array}{l}1.90 \mathrm{E}-01 \\
9.19 \mathrm{E}-02 \\
1.41 \mathrm{E}-01\end{array}$ & $\begin{array}{l}1.78 \mathrm{E}-01 \\
2.40 \mathrm{E}-01 \\
1.96 \mathrm{E}-01\end{array}$ & $\begin{array}{l}1.49 E-01 \\
2.20 E-01 \\
1.68 E-01\end{array}$ & $I / D$ & $0.00 E+00$ \\
\hline Two & $A G$ & $\begin{array}{l}2.30 E+02 \\
9.88 E+02 \\
\text { Total }\end{array}$ & $\begin{array}{l}-6.93 E-01 \\
-7.22 E-01 \\
-7.07 E-01\end{array}$ & $\begin{array}{l}2.62 \mathrm{E}-02 \\
1.13 \mathrm{E}-02 \\
2.40 \mathrm{E}-02\end{array}$ & $\begin{array}{l}8.53 \mathrm{E}-02 \\
4.05 \mathrm{E}-02 \\
5.97 \mathrm{E}-02\end{array}$ & $2.60 E+01$ & $4.68 E+01$ \\
\hline Two & $\mathrm{AI}$ & $\begin{array}{l}2.02 E+02 \\
1.16 E+03 \\
\text { Total }\end{array}$ & $\begin{array}{l}1.24 E+00 \\
3.71 E-01 \\
8.07 E-01\end{array}$ & $\begin{array}{l}8.22 E-01 \\
2.00 E-01 \\
7.17 E-01\end{array}$ & $\begin{array}{l}3.67 \mathrm{E}-01 \\
1.46 \mathrm{E}-01 \\
2.50 \mathrm{E}-01\end{array}$ & $\mathrm{I} / \mathrm{D}$ & $1.48 \mathrm{E}+02$ \\
\hline Two & AJ & $\begin{array}{l}2.02 E+02 \\
1.16 E+03 \\
\text { Total }\end{array}$ & $\begin{array}{l}-8.84 E-01 \\
-5.91 E-01 \\
-7.38 E-01\end{array}$ & $\begin{array}{l}8.98 E-02 \\
6.25 E-01 \\
4.30 E-01\end{array}$ & $\begin{array}{l}7.78 \mathrm{E}-01 \\
1.53 \mathrm{E}+00 \\
1.08 \mathrm{E}+00\end{array}$ & $\mathrm{I} / \mathrm{D}$ & $5.37 E+00$ \\
\hline Two & $A M$ & $\begin{array}{l}2.30 \mathrm{E}+02 \\
9.88 \mathrm{E}+02 \\
\text { Total }\end{array}$ & $\begin{array}{r}3.35 \mathrm{E}-02 \\
-2.86 \mathrm{E}-02 \\
2.44 \mathrm{E}-03\end{array}$ & $\begin{array}{l}8.65 \mathrm{E}-02 \\
1.36 \mathrm{E}-02 \\
6.50 \mathrm{E}-02\end{array}$ & $\begin{array}{l}8.37 \mathrm{E}-02 \\
1.40 \mathrm{E}-02 \\
5.36 \mathrm{E}-02\end{array}$ & $I / D$ & $1.09 E+00$ \\
\hline Two & AN & $\begin{array}{l}2.30 \mathrm{E}+02 \\
9.88 \mathrm{E}+02 \\
\text { Total }\end{array}$ & $\begin{array}{l}8.54 \mathrm{E}-02 \\
4.42 \mathrm{E}-03 \\
4.49 \mathrm{E}-02\end{array}$ & $\begin{array}{l}3.65 \mathrm{E}-02 \\
4.19 \mathrm{E}-02 \\
5.66 \mathrm{E}-02\end{array}$ & $\begin{array}{l}3.36 \mathrm{E}-02 \\
4.17 \mathrm{E}-02 \\
3.39 \mathrm{E}-02\end{array}$ & $\mathrm{I} / \mathrm{D}$ & $0.00 E+00$ \\
\hline Two & $A U$ & $\begin{array}{l}2.02 \mathrm{E}+02 \\
1.16 \mathrm{E}+03 \\
\text { Total }\end{array}$ & $\begin{array}{l}1.17 E+00 \\
1.37 E+00 \\
1.27 E+00\end{array}$ & $\begin{array}{l}6.94 \mathrm{E}-01 \\
2.54 \mathrm{E}-01 \\
4.80 \mathrm{E}-01\end{array}$ & $\begin{array}{l}3.20 \mathrm{E}-01 \\
1.08 \mathrm{E}-01 \\
2.13 \mathrm{E}-01\end{array}$ & $2.71 E+02$ & $2.67 E+02$ \\
\hline Two & BF & $\begin{array}{l}2.30 \mathrm{E}+02 \\
9.88 \mathrm{E}+02 \\
\text { Total }\end{array}$ & $\begin{array}{l}5.80 E-02 \\
1.13 E-01 \\
8.57 E-02\end{array}$ & $\begin{array}{l}2.51 \mathrm{E}-02 \\
1.75 \mathrm{E}-01 \\
1.16 \mathrm{E}-01\end{array}$ & $\begin{array}{l}2.37 E-02 \\
1.57 E-01 \\
1.01 E-01\end{array}$ & $\mathrm{I} / \mathrm{D}$ & $2.13 E+01$ \\
\hline Two & $E$ & $\begin{array}{l}2.02 E+02 \\
1.16 E+03 \\
\text { Total }\end{array}$ & $\begin{array}{l}6.77 \mathrm{E}-02 \\
5.38 \mathrm{E}-02 \\
6.07 \mathrm{E}-02\end{array}$ & $\begin{array}{l}2.73 \mathrm{E}-02 \\
8.82 \mathrm{E}-02 \\
5.89 \mathrm{E}-02\end{array}$ & $\begin{array}{l}2.55 \mathrm{E}-02 \\
8.37 \mathrm{E}-02 \\
5.54 \mathrm{E}-02\end{array}$ & $1.63 \mathrm{E}+02$ & $6.61 E+01$ \\
\hline
\end{tabular}


TABLE F.7. (Contd)

\begin{tabular}{|c|c|c|c|c|c|c|c|}
\hline \multirow[b]{2}{*}{ Round } & \multirow[b]{2}{*}{$\underline{L a b}$} & \multirow{2}{*}{$\begin{array}{c}A_{a i}, \\
p C i / L\end{array}$} & \multirow[b]{2}{*}{$B_{r}$} & \multirow[b]{2}{*}{$S_{B}$} & \multirow[b]{2}{*}{$S_{A}$} & \multicolumn{2}{|c|}{$M D A, p C i / L$} \\
\hline & & & & & & $\operatorname{MDA}(1)$ & $\operatorname{MDA}(2)$ \\
\hline Two & G & $\begin{array}{l}2.02 E+02 \\
1.16 E+03 \\
\text { Total }\end{array}$ & $\begin{array}{r}-8.91 \mathrm{E}-02 \\
2.79 \mathrm{E}-02 \\
-3.06 \mathrm{E}-02\end{array}$ & $\begin{array}{l}3.47 \mathrm{E}-02 \\
4.15 \mathrm{E}-02 \\
7.26 \mathrm{E}-02\end{array}$ & $\begin{array}{l}3.80 \mathrm{E}-02 \\
4.03 \mathrm{E}-02 \\
3.51 \mathrm{E}-02\end{array}$ & $1.32 E+01$ & $1.65 E+01$ \\
\hline Two & $H$ & $\begin{array}{l}2.30 \mathrm{E}+02 \\
9.88 \mathrm{E}+02 \\
\text { Tota } 1\end{array}$ & $\begin{array}{l}-4.20 \mathrm{E}-02 \\
-4.82 \mathrm{E}-02 \\
-4.51 \mathrm{E}-02\end{array}$ & $\begin{array}{l}1.96 \mathrm{E}-02 \\
3.09 \mathrm{E}-03 \\
1.30 \mathrm{E}-02\end{array}$ & $\begin{array}{l}2.05 \mathrm{E}-02 \\
3.25 \mathrm{E}-03 \\
1.31 \mathrm{E}-02\end{array}$ & $\mathrm{I} / \mathrm{D}$ & $7.10 E+00$ \\
\hline Two & $J$ & $\begin{array}{l}2.02 E+02 \\
1.16 E+03 \\
\text { Tota1 }\end{array}$ & $\begin{array}{r}-1.32 \mathrm{E}-02 \\
4.61 \mathrm{E}-03 \\
-4.30 \mathrm{E}-03\end{array}$ & $\begin{array}{l}2.44 \mathrm{E}-02 \\
2.17 \mathrm{E}-02 \\
2.29 \mathrm{E}-02\end{array}$ & $\begin{array}{l}2.47 \mathrm{E}-02 \\
2.16 \mathrm{E}-02 \\
2.08 \mathrm{E}-02\end{array}$ & $\mathrm{I} / \mathrm{D}$ & $1.68 \mathrm{E}+02$ \\
\hline Two & K & $\begin{array}{l}2.30 \mathrm{E}+02 \\
9.88 \mathrm{E}+02 \\
\text { Tota } 1\end{array}$ & $\begin{array}{r}2.90 \mathrm{E}-03 \\
-1.96 \mathrm{E}-02 \\
-8.33 \mathrm{E}-03\end{array}$ & $\begin{array}{l}7.03 \mathrm{E}-02 \\
4.36 \mathrm{E}-02 \\
5.37 \mathrm{E}-02\end{array}$ & $\begin{array}{l}7.01 \mathrm{E}-02 \\
4.45 \mathrm{E}-02 \\
5.25 \mathrm{E}-02\end{array}$ & $2.59 E+03$ & $7.10 E+01$ \\
\hline Two & L & $\begin{array}{l}2.02 \mathrm{E}+02 \\
1.16 \mathrm{E}+03 \\
\text { Total }\end{array}$ & $\begin{array}{l}3.63 \mathrm{E}-02 \\
6.64 \mathrm{E}-02 \\
5.13 \mathrm{E}-02\end{array}$ & $\begin{array}{l}4.49 \mathrm{E}-02 \\
5.76 \mathrm{E}-02 \\
4.91 \mathrm{E}-02\end{array}$ & $\begin{array}{l}4.33 \mathrm{E}-02 \\
5.41 \mathrm{E}-02 \\
4.38 \mathrm{E}-02\end{array}$ & $1.04 \mathrm{E}+01$ & $1.59 E+01$ \\
\hline Two & M & $\begin{array}{l}2.30 \mathrm{E}+02 \\
9.88 \mathrm{E}+02 \\
\text { Tota } 1\end{array}$ & $\begin{array}{r}4.78 \mathrm{E}-02 \\
-1.48 \mathrm{E}-02 \\
1.65 \mathrm{E}-02\end{array}$ & $\begin{array}{l}9.54 \mathrm{E}-02 \\
2.99 \mathrm{E}-02 \\
7.19 \mathrm{E}-02\end{array}$ & $\begin{array}{l}9.10 \mathrm{E}-02 \\
3.03 \mathrm{E}-02 \\
6.07 \mathrm{E}-02\end{array}$ & $5.00 E+01$ & $5.04 E+01$ \\
\hline Two & $\mathrm{N}$ & $\begin{array}{l}2.02 \mathrm{E}+02 \\
1.16 \mathrm{E}+03 \\
\text { Tota1 }\end{array}$ & $\begin{array}{r}-3.71 \mathrm{E}-02 \\
1.73 \mathrm{E}-03 \\
-1.38 \mathrm{E}-02\end{array}$ & $\begin{array}{l}3.15 \mathrm{E}-02 \\
3.11 \mathrm{E}-02 \\
3.44 \mathrm{E}-02\end{array}$ & $\begin{array}{l}3.27 \mathrm{E}-02 \\
3.11 \mathrm{E}-02 \\
2.74 \mathrm{E}-02\end{array}$ & $\mathrm{I} / \mathrm{D}$ & $0.00 E+00$ \\
\hline Two & 0 & $\begin{array}{l}2.02 E+02 \\
1.16 E+03 \\
\text { Total }\end{array}$ & $\begin{array}{l}5.18 \mathrm{E}-01 \\
4.20 \mathrm{E}-02 \\
2.80 \mathrm{E}-01\end{array}$ & $\begin{array}{l}2.90 \mathrm{E}-01 \\
7.24 \mathrm{E}-02 \\
3.22 \mathrm{E}-01\end{array}$ & $\begin{array}{l}1.91 \mathrm{E}-01 \\
6.95 \mathrm{E}-02 \\
1.29 \mathrm{E}-01\end{array}$ & $I / D$ & $0.00 E+00$ \\
\hline Two & $S$ & $\begin{array}{l}2.02 E+02 \\
1.16 E+03 \\
\text { Total }\end{array}$ & $\begin{array}{l}4.59 \mathrm{E}-02 \\
2.91 \mathrm{E}-02 \\
3.75 \mathrm{E}-02\end{array}$ & $\begin{array}{l}2.60 \mathrm{E}-01 \\
8.40 \mathrm{E}-02 \\
1.73 \mathrm{E}-01\end{array}$ & $\begin{array}{l}2.49 \mathrm{E}-01 \\
8.16 \mathrm{E}-02 \\
1.66 \mathrm{E}-01\end{array}$ & $I / D$ & $4.36 E+01$ \\
\hline
\end{tabular}


TABLE F.8. ${ }^{137} \mathrm{Cs}$ Relative Bias and Precision, and MDA (AMDA $=59 \mathrm{pCi} / \mathrm{L}$ )

\begin{tabular}{|c|c|c|c|c|c|c|c|}
\hline \multirow[b]{2}{*}{ Round } & \multirow[b]{2}{*}{$\underline{L a b}$} & \multirow{2}{*}{$\begin{array}{c}\mathrm{A}_{\mathrm{ai}}, \\
\mathrm{pCi} / \mathrm{L}\end{array}$} & \multirow[b]{2}{*}{$B_{r}$} & \multirow[b]{2}{*}{$S_{B}$} & \multirow[b]{2}{*}{$S_{A}$} & \multicolumn{2}{|c|}{$M D A, p C i / L$} \\
\hline & & & & & & $M D A(1)$ & $\operatorname{MDA}(2)$ \\
\hline One & G & $\begin{array}{l}1.51 \mathrm{E}+03 \\
1.38 \mathrm{E}+04 \\
\text { Total }\end{array}$ & $\begin{array}{r}2.96 \mathrm{E}-02 \\
-1.73 \mathrm{E}-02 \\
6.14 \mathrm{E}-03\end{array}$ & $\begin{array}{l}2.56 \mathrm{E}-02 \\
3.73 \mathrm{E}-02 \\
3.85 \mathrm{E}-02\end{array}$ & $\begin{array}{l}2.49 \mathrm{E}-02 \\
3.80 \mathrm{E}-02 \\
2.87 \mathrm{E}-02\end{array}$ & 1. $28 \mathrm{E}+01$ & 1. $14 \mathrm{E}+01$ \\
\hline One & I & $\begin{array}{l}1.51 E+03 \\
1.38 E+04 \\
\text { Tota } 1\end{array}$ & $\begin{array}{r}-6.62 \mathrm{E}-03 \\
1.45 \mathrm{E}-02 \\
1.16 \mathrm{E}-02\end{array}$ & $\begin{array}{l}5.70 E-10 \\
0.00 E+00 \\
3.94 E-03\end{array}$ & $\begin{array}{l}0.00 \mathrm{E}+00 \\
0.00 \mathrm{E}+00 \\
0.00 \mathrm{E}+00\end{array}$ & $I / D$ & $0.00 E+00$ \\
\hline One & J & $\begin{array}{l}1.51 E+03 \\
1.38 E+04 \\
\text { Tota1 }\end{array}$ & $\begin{array}{l}-8.61 E-02 \\
-7.37 E-02 \\
-7.99 E-02\end{array}$ & $\begin{array}{l}6.62 \mathrm{E}-03 \\
1.66 \mathrm{E}-02 \\
1.32 \mathrm{E}-02\end{array}$ & $\begin{array}{l}7.25 \mathrm{E}-03 \\
1.79 \mathrm{E}-02 \\
1.22 \mathrm{E}-02\end{array}$ & $8.96 E+01$ & $5.48 E+01$ \\
\hline One & K & $\begin{array}{l}1.51 E+03 \\
1.38 E+04 \\
\text { Tota } 1\end{array}$ & $\begin{array}{l}-1.13 \mathrm{E}-01 \\
-2.42 \mathrm{E}-02 \\
-6.84 \mathrm{E}-02\end{array}$ & $\begin{array}{l}1.67 \mathrm{E}-01 \\
4.18 \mathrm{E}-03 \\
1.16 \mathrm{E}-01\end{array}$ & $\begin{array}{l}1.88 \mathrm{E}-01 \\
4.29 \mathrm{E}-03 \\
1.19 \mathrm{E}-01\end{array}$ & $I / D$ & $0.00 E+00$ \\
\hline One & $L$ & $\begin{array}{l}1.51 E+03 \\
1.38 E+04 \\
\text { Tota } 1\end{array}$ & $\begin{array}{l}-1.56 \mathrm{E}-02 \\
-5.39 \mathrm{E}-03 \\
-1.05 \mathrm{E}-02\end{array}$ & $\begin{array}{l}7.74 E-03 \\
7.20 \mathrm{E}-03 \\
8.73 \mathrm{E}-03\end{array}$ & $\begin{array}{l}7.86 \mathrm{E}-03 \\
7.24 \mathrm{E}-03 \\
6.76 \mathrm{E}-03\end{array}$ & $3.88 E+01$ & $1.90 \mathrm{E}+01$ \\
\hline One & M & $\begin{array}{l}1.38 E+04 \\
1.5 \cdot 1 E+03 \\
\text { Total }\end{array}$ & $\begin{array}{l}-1.16 \mathrm{E}-02 \\
-3.97 \mathrm{E}-03 \\
-7.78 \mathrm{E}-03\end{array}$ & $\begin{array}{l}5.86 \mathrm{E}-03 \\
7.28 \mathrm{E}-03 \\
7.24 \mathrm{E}-03\end{array}$ & $\begin{array}{l}5.93 \mathrm{E}-03 \\
7.31 \mathrm{E}-03 \\
5.96 \mathrm{E}-03\end{array}$ & $6.78 E+00$ & $7.48 \mathrm{E}+00$ \\
\hline One & $\mathrm{N}$ & $\begin{array}{l}1.51 E+03 \\
1.38 E+04 \\
\text { Total }\end{array}$ & $\begin{array}{l}-9.27 \mathrm{E}-02 \\
-1.45 \mathrm{E}-01 \\
-1.19 \mathrm{E}-01\end{array}$ & $\begin{array}{l}4.14 \mathrm{E}-02 \\
1.26 \mathrm{E}-02 \\
3.96 \mathrm{E}-02\end{array}$ & $\begin{array}{l}4.56 \mathrm{E}-02 \\
1.47 \mathrm{E}-02 \\
3.03 \mathrm{E}-02\end{array}$ & $\mathrm{I} / \mathrm{D}$ & $0.00 E+00$ \\
\hline One & 0 & $\begin{array}{l}1.51 E+03 \\
1.38 E+04 \\
\text { Total }\end{array}$ & $\begin{array}{l}-1.70 \mathrm{E}-01 \\
-1.49 \mathrm{E}-01 \\
-1.59 \mathrm{E}-01\end{array}$ & $\begin{array}{l}7.16 \mathrm{E}-03 \\
6.52 \mathrm{E}-03 \\
1.26 \mathrm{E}-02\end{array}$ & $\begin{array}{l}8.63 \mathrm{E}-03 \\
7.67 \mathrm{E}-03 \\
7.30 \mathrm{E}-03\end{array}$ & $5.37 \mathrm{E}+01$ & $5.29 E+01$ \\
\hline Two & $A D$ & $\begin{array}{l}2.34 E+02 \\
1.35 E+03 \\
\text { Total }\end{array}$ & $\begin{array}{r}2.56 E-02 \\
-5.67 E-03 \\
9.98 E-03\end{array}$ & $\begin{array}{l}7.41 \mathrm{E}-02 \\
4.27 \mathrm{E}-03 \\
5.00 \mathrm{E}-02\end{array}$ & $\begin{array}{l}7.23 \mathrm{E}-02 \\
4.30 \mathrm{E}-03 \\
4.58 \mathrm{E}-02\end{array}$ & $I / D$ & $1.02 E+00$ \\
\hline Two & $A E$ & $\begin{array}{l}2.67 E+02 \\
1.15 E+03 \\
\text { Total }\end{array}$ & $\begin{array}{r}3.75 E-02 \\
-6.42 E-02 \\
-1.34 E-02\end{array}$ & $\begin{array}{l}1.57 \mathrm{E}-01 \\
2.05 \mathrm{E}-01 \\
1.73 \mathrm{E}-01\end{array}$ & $\begin{array}{l}1.52 E-01 \\
2.20 E-01 \\
1.69 E-01\end{array}$ & $\mathrm{I} / \mathrm{D}$ & $0.00 E+00$ \\
\hline
\end{tabular}


TABLE F.8. (Contd)

\begin{tabular}{|c|c|c|c|c|c|c|c|}
\hline \multirow[b]{2}{*}{ Round } & \multirow[b]{2}{*}{ Lab } & \multirow{2}{*}{$\begin{array}{c}\mathrm{A}_{\mathrm{a} i}, \\
\mathrm{pCi} \mathrm{L} / \mathrm{L}\end{array}$} & \multirow[b]{2}{*}{${ }^{B}{ }_{r}$} & \multirow[b]{2}{*}{$S_{B}$} & \multirow[b]{2}{*}{$S_{A}$} & \multicolumn{2}{|c|}{$M D A, p C i / L$} \\
\hline & & & & & & $\operatorname{MDA}(1)$ & $\operatorname{MDA}(2)$ \\
\hline Two & $A G$ & $\begin{array}{l}2.67 E+02 \\
1.15 E+03 \\
\text { Total }\end{array}$ & $\begin{array}{l}-5.18 \mathrm{E}-01 \\
-7.20 \mathrm{E}-01 \\
-6.19 \mathrm{E}-01\end{array}$ & $\begin{array}{l}3.45 \mathrm{E}-01 \\
2.48 \mathrm{E}-02 \\
2.45 \mathrm{E}-01\end{array}$ & $\begin{array}{l}7.16 \mathrm{E}-01 \\
8.86 \mathrm{E}-02 \\
4.56 \mathrm{E}-01\end{array}$ & $3.47 E+01$ & $3.81 E+01$ \\
\hline Two & AI & $\begin{array}{l}2.34 \mathrm{E}+02 \\
1.35 \mathrm{E}+03 \\
\text { Tota } 1\end{array}$ & $\begin{array}{l}9.33 \mathrm{E}-01 \\
3.05 \mathrm{E}-01 \\
6.19 \mathrm{E}-01\end{array}$ & $\begin{array}{l}2.71 \mathrm{E}-01 \\
7.26 \mathrm{E}-02 \\
3.87 \mathrm{E}-01\end{array}$ & $\begin{array}{l}1.40 \mathrm{E}-01 \\
5.57 \mathrm{E}-02 \\
9.53 \mathrm{E}-02\end{array}$ & $I / D$ & $1.49 E+02$ \\
\hline Two & $\mathrm{AJ}$ & $\begin{array}{l}2.34 \mathrm{E}+02 \\
1.35 \mathrm{E}+03 \\
\text { Total }\end{array}$ & $\begin{array}{l}5.54 \mathrm{E}-01 \\
5.59 \mathrm{E}-01 \\
5.57 \mathrm{E}-01\end{array}$ & $\begin{array}{l}8.66 \mathrm{E}-02 \\
2.38 \mathrm{E}-03 \\
5.48 \mathrm{E}-02\end{array}$ & $\begin{array}{l}5.57 \mathrm{E}-02 \\
1.53 \mathrm{E}-03 \\
3.52 \mathrm{E}-02\end{array}$ & $\mathrm{I} / \mathrm{D}$ & $9.68 \mathrm{E}+01$ \\
\hline Two & AM & $\begin{array}{l}2.67 E+02 \\
1.15 E+03 \\
\text { Tota } 1\end{array}$ & $\begin{array}{r}1.51 \mathrm{E}-02 \\
-4.95 \mathrm{E}-03 \\
5.06 \mathrm{E}-03\end{array}$ & $\begin{array}{l}6.02 \mathrm{E}-02 \\
2.87 \mathrm{E}-02 \\
4.36 \mathrm{E}-02\end{array}$ & $\begin{array}{l}5.93 \mathrm{E}-02 \\
2.89 \mathrm{E}-02 \\
4.17 \mathrm{E}-02\end{array}$ & $I / D$ & $2.37 E+01$ \\
\hline Two & AN & $\begin{array}{l}2.67 E+02 \\
1.15 E+03 \\
\text { Tota } 1\end{array}$ & $\begin{array}{r}5.17 \mathrm{E}-02 \\
-3.58 \mathrm{E}-02 \\
7.92 \mathrm{E}-03\end{array}$ & $\begin{array}{l}2.54 \mathrm{E}-02 \\
3.33 \mathrm{E}-02 \\
5.48 \mathrm{E}-02\end{array}$ & $\begin{array}{l}2.41 \mathrm{E}-02 \\
3.45 \mathrm{E}-02 \\
2.66 \mathrm{E}-02\end{array}$ & $I / D$ & $0.00 E+00$ \\
\hline Two & $A U$ & $\begin{array}{l}2.34 E+02 \\
1.35 E+03 \\
\text { Total }\end{array}$ & $\begin{array}{l}1.76 E+00 \\
2.55 E+00 \\
2.16 E+00\end{array}$ & $\begin{array}{l}1.32 E+00 \\
1.28 E-01 \\
9.43 E-01\end{array}$ & $\begin{array}{l}4.77 \mathrm{E}-01 \\
3.61 \mathrm{E}-02 \\
3.03 \mathrm{E}-01\end{array}$ & $1.32 E+03$ & $1.31 E+03$ \\
\hline Two & $B F$ & $\begin{array}{l}2.67 E+02 \\
1.15 E+03 \\
\text { Tota } 1\end{array}$ & $\begin{array}{l}6.12 \mathrm{E}-02 \\
9.86 \mathrm{E}-02 \\
7.99 \mathrm{E}-02\end{array}$ & $\begin{array}{l}2.16 \mathrm{E}-02 \\
1.00 \mathrm{E}-01 \\
6.80 \mathrm{E}-02\end{array}$ & $\begin{array}{l}2.04 \mathrm{E}-02 \\
9.12 \mathrm{E}-02 \\
5.91 \mathrm{E}-02\end{array}$ & $\mathrm{I} / \mathrm{D}$ & $2.68 \mathrm{E}+00$ \\
\hline Two & $\mathrm{E}$ & $\begin{array}{l}2.34 E+02 \\
1.35 E+03 \\
\text { Tota } 1\end{array}$ & $\begin{array}{l}1.84 \mathrm{E}-01 \\
6.29 \mathrm{E}-02 \\
1.23 \mathrm{E}-01\end{array}$ & $\begin{array}{l}1.91 \mathrm{E}-01 \\
8.97 \mathrm{E}-02 \\
1.49 \mathrm{E}-01\end{array}$ & $\begin{array}{l}1.61 \mathrm{E}-01 \\
8.44 \mathrm{E}-02 \\
1.15 \mathrm{E}-01\end{array}$ & $1.21 E+01$ & $7.06 \mathrm{E}+01$ \\
\hline Two & G & $\begin{array}{l}2.34 E+02 \\
1.35 E+03 \\
\text { Tota } 1\end{array}$ & $\begin{array}{l}-1.15 \mathrm{E}-01 \\
-1.53 \mathrm{E}-02 \\
-6.53 \mathrm{E}-02\end{array}$ & $\begin{array}{l}3.80 \mathrm{E}-02 \\
4.98 \mathrm{E}-02 \\
6.76 \mathrm{E}-02\end{array}$ & $\begin{array}{l}4.29 \mathrm{E}-02 \\
5.05 \mathrm{E}-02 \\
4.19 \mathrm{E}-02\end{array}$ & $6.52 \mathrm{E}+00$ & $8.75 E+00$ \\
\hline Two & H & $\begin{array}{l}2.67 E+02 \\
1.15 E+03 \\
\text { Total }\end{array}$ & $\begin{array}{r}2.12 \mathrm{E}-02 \\
-1.42 \mathrm{E}-02 \\
3.53 \mathrm{E}-03\end{array}$ & $\begin{array}{l}3.48 \mathrm{E}-02 \\
2.18 \mathrm{E}-02 \\
3.24 \mathrm{E}-02\end{array}$ & $\begin{array}{l}3.41 \mathrm{E}-02 \\
2.21 \mathrm{E}-02 \\
2.57 \mathrm{E}-02\end{array}$ & $\mathrm{I} / \mathrm{D}$ & $7.10 E+00$ \\
\hline
\end{tabular}


TABLE F.8. (Contd)

\begin{tabular}{|c|c|c|c|c|c|c|c|}
\hline \multirow[b]{2}{*}{ Round } & \multirow[b]{2}{*}{$\underline{L a b}$} & \multirow{2}{*}{$\begin{array}{c}A_{a i}, \\
\mathrm{pC} i / L\end{array}$} & \multirow[b]{2}{*}{${ }^{B} r$} & \multirow[b]{2}{*}{$S_{B}$} & \multirow[b]{2}{*}{$S_{A}$} & \multicolumn{2}{|c|}{ MDA, $\mathrm{pCi} / \mathrm{L}$} \\
\hline & & & & & & $\operatorname{MDA}(1)$ & $\operatorname{MDA}(2)$ \\
\hline Two & $\mathrm{J}$ & $\begin{array}{l}2.34 E+02 \\
1.35 E+03 \\
\text { Tota T }\end{array}$ & $\begin{array}{r}2.85 \mathrm{E}-03 \\
-3.21 \mathrm{E}-03 \\
-1.79 \mathrm{E}-04\end{array}$ & $\begin{array}{l}1.93 \mathrm{E}-02 \\
1.13 \mathrm{E}-02 \\
1.45 \mathrm{E}-02\end{array}$ & $\begin{array}{l}1.92 \mathrm{E}-02 \\
1.13 \mathrm{E}-02 \\
1.41 \mathrm{E}-02\end{array}$ & $\mathrm{I} / \mathrm{D}$ & $4.08 E+01$ \\
\hline Two & K & $\begin{array}{l}2.67 E+02 \\
1.15 E+03 \\
\text { Tota } 1\end{array}$ & $\begin{array}{l}-2.00 \mathrm{E}-02 \\
-7.95 \mathrm{E}-02 \\
-4.97 \mathrm{E}-02\end{array}$ & $\begin{array}{l}1.89 \mathrm{E}-02 \\
9.57 \mathrm{E}-02 \\
6.98 \mathrm{E}-02\end{array}$ & $\begin{array}{l}1.92 \mathrm{E}-02 \\
1.04 \mathrm{E}-01 \\
6.69 \mathrm{E}-02\end{array}$ & $1.59 E+03$ & $2.68 \mathrm{E}+01$ \\
\hline Two & L & $\begin{array}{l}2.34 E+02 \\
1.35 E+03 \\
\text { Tota } 1\end{array}$ & $\begin{array}{l}6.56 \mathrm{E}-02 \\
2.88 \mathrm{E}-02 \\
4.72 \mathrm{E}-02\end{array}$ & $\begin{array}{l}5.72 \mathrm{E}-02 \\
2.55 \mathrm{E}-02 \\
4.44 \mathrm{E}-02\end{array}$ & $\begin{array}{l}5.37 \mathrm{E}-02 \\
2.48 \mathrm{E}-02 \\
3.74 \mathrm{E}-02\end{array}$ & $2.72 E+00$ & $1.01 E+01$ \\
\hline Two & M & $\begin{array}{l}2.67 E+02 \\
1.15 E+03 \\
\text { Total } 1\end{array}$ & $\begin{array}{r}3.75 \mathrm{E}-03 \\
-2.14 \mathrm{E}-02 \\
-8.82 \mathrm{E}-03\end{array}$ & $\begin{array}{l}8.01 \mathrm{E}-02 \\
1.74 \mathrm{E}-02 \\
5.36 \mathrm{E}-02\end{array}$ & $\begin{array}{l}7.98 \mathrm{E}-02 \\
1.78 \mathrm{E}-02 \\
5.17 \mathrm{E}-02\end{array}$ & $8.85 E+01$ & $8.44 E+01$ \\
\hline Two & $\mathrm{N}$ & $\begin{array}{l}2.34 E+02 \\
1.35 E+03 \\
\text { Total }\end{array}$ & $\begin{array}{l}3.22 \mathrm{E}-01 \\
8.07 \mathrm{E}-02 \\
2.01 \mathrm{E}-01\end{array}$ & $\begin{array}{l}9.03 \mathrm{E}-02 \\
1.48 \mathrm{E}-02 \\
1.44 \mathrm{E}-01\end{array}$ & $\begin{array}{l}6.83 E-02 \\
1.37 E-02 \\
4.41 E-02\end{array}$ & $I / D$ & $0.00 E+00$ \\
\hline Two & 0 & $\begin{array}{l}2.34 \mathrm{E}+02 \\
1.35 \mathrm{E}+03 \\
\text { Tota } 1\end{array}$ & $\begin{array}{r}-8.83 \mathrm{E}-02 \\
5.35 \mathrm{E}-02 \\
-1.74 \mathrm{E}-02\end{array}$ & $\begin{array}{l}2.47 E-02 \\
1.86 E-02 \\
8.01 E-02\end{array}$ & $\begin{array}{l}2.71 E-02 \\
1.77 E-02 \\
2.04 E-02\end{array}$ & $I / D$ & $0.00 E+00$ \\
\hline Two & $\mathrm{s}$ & $\begin{array}{l}2.34 \mathrm{E}+02 \\
1.35 \mathrm{E}+03 \\
\text { Total }\end{array}$ & $\begin{array}{r}1.21 \mathrm{E}-02 \\
-4.96 \mathrm{E}-02 \\
-1.87 \mathrm{E}-02\end{array}$ & $\begin{array}{l}1.98 \mathrm{E}-01 \\
6.62 \mathrm{E}-02 \\
1.36 \mathrm{E}-01\end{array}$ & $\begin{array}{l}1.96 E-01 \\
6.97 E-02 \\
1.32 E-01\end{array}$ & $I / D$ & $3.79 E+01$ \\
\hline
\end{tabular}




\section{APPENDIX G}

PROPAGATION OF ERROR IN SPIKED ARTIFICIAL URINE SAMPLES 


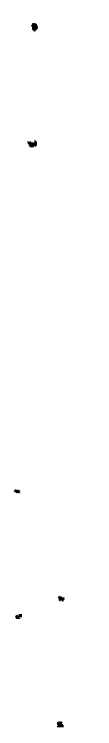




\section{APPENDIX G}

\section{PROPAGATION OF ERROR IN SPIKED ARTIFICIAL URINE SAMPLES}

The methods used to estimate the total error in the in vitro test samples were the same as those discussed by Kanipe (1977). Briefly, the individual components of the total error were assumed to be independent, normaliy distributed variables and that propagation of error for the manipulation of various functions could be expressed as below.

$$
\begin{aligned}
& \text { Function } \\
& Q=X \pm Y \\
& Q=a X \pm b Y \\
& Q=X Y \\
& Q=X / Y
\end{aligned}
$$

\section{Error Formula}

$$
\begin{aligned}
& \sigma_{Q}=\left(\sigma_{x}{ }^{2}+\sigma_{y}{ }^{2}\right)^{\frac{1}{2}} \\
& \sigma_{Q}=\left(a^{2} \sigma_{x}{ }^{2}+b^{2} \sigma_{y}{ }^{2}\right)^{\frac{1}{2}} \\
& \sigma_{Q}=X Y\left(\sigma_{x}{ }^{2} / X^{2}+\sigma_{y}{ }^{2} / Y^{2}\right)^{\frac{1}{2}} \\
& \sigma_{Q}=X / Y\left(\sigma_{x}{ }^{2} / X^{2}+\sigma_{y}{ }^{2} / Y^{2}\right)^{\frac{1}{2}}
\end{aligned}
$$

Using the error formulas above, the equations detailed in Appendix B, and the error estimates quoted in the NBS certificates supplied for each nuclide, the total error in the prepared samples was estimated. 


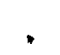

•

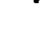

. 
DISTRIBUTION

No. of

Copies

OFFSITE

10 DOE/Office of Scientific and

Technical Information

DOE Headquarters

R. P. Berube, Acting Director

Assistant Secretary for

Environment, Safety, and Health

U.S. Department of Energy

Washington, DC 20545

D. F. Bunch, Deputy Assistant Secretary for Safety, Health, and Quality Assurance

U.S. Department of Energy

Washington, DC 20545

N. Goldenberg, Acting Director Office of Nuclear Safety

U.S. Department of Energy

Washington, DC 20545

Bette L. Murphy

Office of Nuclear Safety

U.S Department of Energy

Washington, DC 20545

D. R. Nelson

Office of Nuclear Safety

U.S. Department of Energy

Washington, DC 20545

10 E. J. Vallario, Acting Director Radiological Controls Division

U.S. Department of Energy

Washington, DC 20545

Assistant Secretary for

Environment, Safety, and Health

U.S. Department of Energy

Washington, DC 20585
No. of

Copies

DOE Albuquerque Operations Office

R. E. Alexander

Pantex Plant

Mason \& Hanger--Silas Mason Co., Inc.

P.0. Box 30020

Amari110, TX 79177

W. D. Burnett

DOE Sandia National Laboratories

Mail Code 3312, B1dg. 8619

P.0. Box 2800

A1buquerque, NM 87115

G. W. Campbe11

Rockwel1 International

Rocky Flats Plant

P.0. Box 464

Golden, C0 80401

J. W. Doty

Mound Laboratory

Monsanto Research Corporation

Miamisburg, $\mathrm{OH} 45342$

R. Falk

Rockwell International

Rocky Flats Plant

P.0. Box 464

Golden, C0 80401

W. D. Moss

Los Alamos National Laboratory

P.0. Box 1663

Los Alamos, NM 87545

P. M. Ramey

U.S. Department of Energy

Albuquerque Operations Office

P.0. Box 5400

Albuquerque, NM 87115 
No. of

Copies

R. G. Stafford

Los Alamos National Laboratory

P.0. Box 1663

Los Alamos, NM 87545

J. G. Themelis

U.S. Department of Energy

Albuquerque Operations Office P.0. Box 5400

Albuquerque, NM 87115

DOE Chicago Operations Office

L. V. Coulson

Fermi National Accelerator Laboratory

P.0. Box 500

Batavia, IL 60510

R. A. Mayes

U.S. Department of Energy

9800 S. Cass Ave.

Argonne, IL 60439

C. B. Meinhold

Brookhaven National Laboratory

Associated Universities, Inc.

Upton, NY 11973

D. P. O'Neil

Argonne National Laboratory

9800 South Cass Avenue

Argonne, IL 60439

DOE Idaho Operations Office

J. H. Barry

U.S. Department of Energy

Idaho Operations office

785 DOE Place

Idaho Falls, ID 83402

B. L. Rich

EG\&G I daho

P.0. Box 1625

Idaho Falls, ID 83401
No. of

Copies

A. N. Tschaeche

WINCO

M/S CPP -630

P.0. Box 4000

Idaho Falls, ID 83403

DOE Nevada Operations Office

A. E. Bicker

Reynolds Electrical \& Engineering Co., Inc.

P.0. Box 14400

Las Vegas, NV 89114

P. K. Fitzsimmons

U.S. Department of Energy

Nevada Operations Office

P.0. Box 14100

Las Vegas, NV 89114

DOE Oak Ridge Operations Office

R. J. Cloutier

Oak Ridge Associated Universities

P.0. Box 117

Oak Ridge, TN 37831

R. E. Halliburton

Oak Ridge National Laboratory

P.0. Box $X$

Oak Ridge, TN 38730

S. L. Hinnefeld

Westinghouse Materials Co. of Ohio

P.0. Box 398704

Cincinnati, OH 45239

D. B. Howard

U.S. Department of Energy

Oak Ridge Operations Office

P.0. Box E

Oak Ridge, TN 37831 
No. of

Copies

W. T. Mee

$Y-12$

P.0. Box $Y$

Oak Ridge, TN 37830

D. C. Parzyck

Oak Ridge National Laboratory

P.0. Box $X$

Oak Ridge, TN 37830

S. F. Seltzer

Paducah Gaseous Diffusion Plant

P.0. Box 1410

Paducah, KY 42001

J. E. Shoemaker

Oak Ridge Gaseous Diffusion Plant

P.0. Box P

Oak Ridge, TN 37831

F. G. VanLoocke

RMI Company

P.0. Box 579

Ashtabula, $\mathrm{OH} 44004$

E. R. Wagner

Portsmouth Gaseous Diffusion Plant

Martin Marietta Energy Systems

P.0. Box 628

Piketon, $\mathrm{OH} 45661$

DOE San Francisco Operations

Office

T. R. Crites

Lawrence Livermore National Laboratory

P.0. Box 5505

Livermore, CA 94550

J. T. Davis

U.S. Department of Energy

San Francisco Operations Office

1333 Broadway

Oakland, CA 94612
No. of

Copies

R. C. McCall

Stanford Linear Accelerator

P.0. Box 4349

Stanford, CA 94305

R. H. Thomas

DOE Lawrence Berkeley National Laboratory

University of California

Berkeley, CA 94720

G. Warren

Stanford Linear Accelerator

P.0. Box 4349

Stanford, CA 94305

DOE Savannah River Operations Office

D. N. Bridges

U.S. Department of Energy

Savannah River Operations Office P.0. Box A

Aiken, SC 29801

W. C. Reinig

E.I. duPont de Nemours \& Co.

Savannah River Plant

Aiken, SC 29809

EPA Office of Radiation Programs

A. Richardson

401 M Street, SW

Washington, DC 20460

National Center for Devices and

Radiological Health

J. C. Villforth

FDA Bureau of Radiological Health Rockville, MD 20852 
No. of

Copies

National Bureau of Standards

E. H. Eisenhower

National Bureau of Standards

Gaithersburg, MD 20899

R. Loevinger

National Bureau of Standards

Gaithersburg, MD 20899

Nuclear Regulatory Commission

R. E. Alexander

U.S. Nuclear Regulatory Cormission Washington, DC 20555

OTHER

A. Brodsky

16412 Kipling Road

Derwood, MD 20855

F. Bronson

Canberra/RMC

One State Street

Meriden, CT 06450

K. R. Heid

2318 Davison Avenue

Richland, WA 99352

D. McCurdy

Yankee Atomic Electric Co.

1671 Worcester Road

Framingham, MA 01701

R. Mellor

Yankee Atomic Electric Co.

1671 Worcester Road

Framingham, MA 01701

M. Ortiz

Eberl ine Laboratories

3807 Academy Parkway, Sixth N.W.

P.0. Box 2874

Albuquerque, NM 87190
No. of

Copies

B. Wessman

TMA/Norcal

2030 Wright Avenue

Richmond, CA 94804

ONSITE

2 DOE Richland Operations Office

D. T. Evans

D. L. Sours

Westinghouse Hanford Company

R. 0. Budd

2 U.S. Testing Company, Inc.

M. M. Lardy

A. V. Robinson

99 Pacific Northwest Laboratory

W. J. Bair

L. W. Brackenbush

J. T. Denovan

L. G. Faust

D. R. Fisher

G. R. Hoenes

J. A. MacLel lan (50)

J. B. Martin

J. M. Selby (30)

K. L. Soldat

K. L. Swinth

R. J. Traub

M. T. Upton

Health Physics Department Library

Publishing Coordination (2)

Technical Report Files (5) 